Кельчевская Н.Р., Пелымская И.С., Чешко Е.К.

\title{
ВЛИЯНИЕ ЭМОЦИОНАЛЬНОГО ИНТЕЛЛЕКТА РАБОТНИКОВ ПРЕДПРИЯТИЯ НА РЕЗУЛЬТАТЫ ЕГО ДЕЯТЕЛЬНОСТИ
}

монография

Natalya R. Kelchevskaya, Irina S. Pelymskaya, Elizaveta K. Cheshko INFLUENCE OF EMPLOYEES' EMOTIONAL INTELLIGENCE ON THE RESULTS OF THE ENTERPRISE ACTIVITY

Moscow, 2020

\author{
Москва \\ КРЕАТИВНАЯ ЭКОНОМИКА \\ 2020
}


УДК 159.923: 338.2

ББК 88.912

K34

\section{Рецензенты:}

Шапошников В.А. - доктор экономических наук, доцент, профессор кафедры экономики, менеджмента и маркетинга ФГАОУ ВО «Российский государственный профессионально-педагогический университет».

Юзвович Л.И. - доктор экономических наук, профессор, зав. каф. финансов, денежного обращения и кредита ФГБОУ ВО «Уральский государственный экономический университет».

\section{Кельчевская Н.Р., Пелымская И.С., Чешко Е.К.}

K34 Влияние эмоционального интеллекта работников предприятия на результаты его деятельности / Н.Р. Кельчевская, И.С. Пелымская, Е.К. Чешко. М.: Креативная экономика, 2020. - 182 с.

ISBN 978-5-91292-335-7

DOI $10.18334 / 9785912923357$

Монография посвящена оценке влияния эмоционального интеллекта работников на результаты экономической деятельности предприятия. Теоретическая и практическая значимость монографии заключается в расширении научных представлений о развитии предприятия на основе уровня эмоционального интеллекта сотрудников.

В монографии исследуются основные теоретические аспекты эмоционального интеллекта и показано влияние уровня эмоционального интеллекта сотрудников на результаты как их деятельности, так и предприятия, авторами определены и развиты методические подходы к повышению эффективности деятельности предприятия с учетом уровня эмоционального интеллекта сотрудников.

Монография может быть полезна студентам, аспирантам, экономистам, руководителям предприятий и практическим работниками в области экономики предприятия и эмоционального интеллекта.

ISBN 978-5-91292-335-7

(C) Кельчевская Н.Р.,

Пелымская И.С., Чешко Е.К., 2020

(C) Оформление, дизайн обложки

ООО Издательство «Креативная экономика», 2020 


\section{СОДЕРЖАНИЕ}

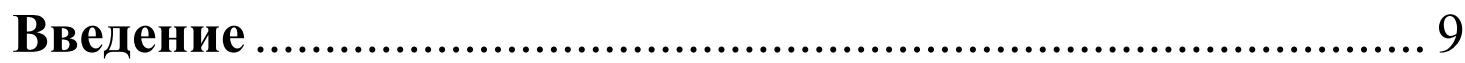

1. Сущность понятия эмоциональный интеллект и его роль в деятельности предприятия 12

1.1. Эволюция научных знаний об эмоциональном интеллекте

1.2. Модель и структура эмоционального интеллекта......... 32

1.3. Роль эмоционального интеллекта в деятельности предприятия 44

2. Анализ влияния эмоционального интеллекта на экономические результаты деятельности предприятия 53

2.1. Исследование влияния эмоционального интеллекта сотрудников на результаты деятельности

2.2. Анализ влияния эмоционального интеллекта на экономические результаты на примере ООО «Концепт Кар» 88

3. Разработка инструментария по оценке и управлению деятельностью предприятия с учетом влияния эмоционального интеллекта 103

3.1. Место эмоционального интеллекта в структуре сбалансированной системы показателей 103

3.2. Алгоритм управления эффективностью деятельности предприятия в зависимости от уровня эмоционального интеллекта

3.3. Апробация результатов исследования......................... 134

Заключение ...................................................................... 156 
Список использованных источников.

Приложение А 171

Результаты эмпирического исследования. 171

Приложение Б 172

Приложение В.............................................................. 176

Интерпретация результатов опросника Д.В. Люсина........ 176 Приложение Г 179

Бланк опроса сотрудника сбытового отдела. 179 
Монография посвящена оценке влияния эмоционального интеллекта работников на результаты экономической деятельности предприятия. Теоретическая и практическая значимость монографии заключается в расширении научных представлений о развитии предприятия на основе уровня эмоционального интеллекта сотрудников.

В монографии исследуются основные теоретические аспекты эмоционального интеллекта и показано влияние уровня эмоционального интеллекта сотрудников на результаты как их деятельности, так и предприятия, авторами определены и развиты методические подходы к повышению эффективности деятельности предприятия с учетом уровня эмоционального интеллекта сотрудников.

Монография может быть полезна студентам, аспирантам, экономистам, руководителям предприятий и практическим работниками в области экономики предприятия и эмоционального интеллекта.

Ключевые слова: эмоциональный интеллект, экономическая деятельность, предприятия малого и среднего бизнеса, оценка, анализ, исследование. 


\section{CONTENT}

Introduction

1. The emotional intelligence insights and its role in the enterprise activity

1.1. Evolution of scientific knowledge about emotional intelligence

1.2. Model and structure of emotional intelligence...... 32

1.3. The role of emotional intelligence in the enterprise activity 44

\section{Analysis of the impact of emotional intelligence} on the enterprise economic performance 53

2.1. Research on the impact of employees ' emotional intelligence on performance results 55

2.2. Analysis of the impact of emotional intelligence on economic results on the example of concept car llc 88

3. Development of tools for evaluating and managing the company's activity taking into account the influence of emotional intelligence 103

3.1. The place of emotional intelligence in the balanced scorecard structure 103

3.2. Algorithm for managing the effectiveness

of the enterprise activity depending on the level of emotional intelligence

3.3. Evaluation of research results.......................................... 134

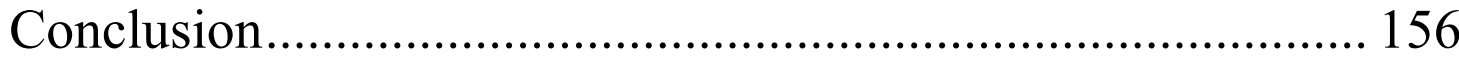


References

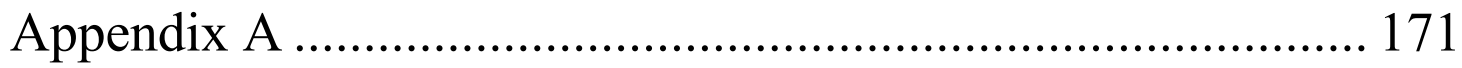

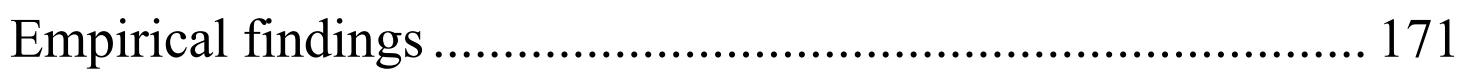

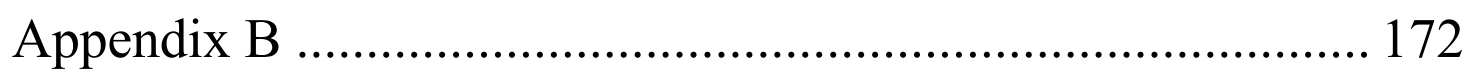

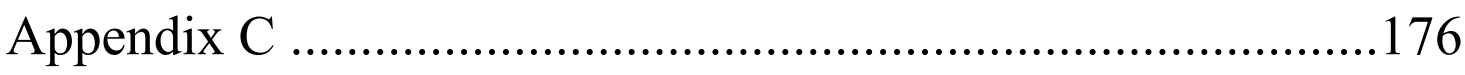

Interpretation of the D.V. Lyusin's questionnaire outcomes......176

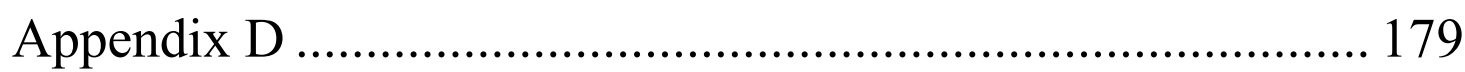

Sales department employee survey form................................. 179 
The monograph is devoted to assessing the impact of employees' emotional intelligence on the results of the enterprise economic activity. The theoretical and practical significance of the monograph is to expand the scientific understanding of the enterprise development based on the level of employees' emotional intelligence.

The main theoretical aspects of emotional intelligence are examined in the monograph. The impact of the level of employees' emotional intelligence on the results of both their activity and the enterprise is shown. The authors have identified and developed methodological approaches to improving the efficiency of the enterprise, taking into account the level of employees' emotional intelligence.

The monograph can be useful for students, postgraduates, economists, business managers and practitioners in the enterprise economics and emotional intelligence.

Keywords: emotional intelligence, economic activity, small and medium-sized businesses, assessment, analysis, research. 


\section{ВВЕДЕНИЕ}

В современной экономической среде обеспечение конкурентоспособности является одной из важных стратегических задач предприятия. Вопрос поддержания конкурентоспособности стоит особенно остро для малых и средних предприятий в реальном секторе экономики, которые работают непосредственно с потребителями и основная часть выручки которых формируется за счет продажи товаров и услуг. И в В2В, и в В2С продажах решение о покупке товара или услуги принимают люди и от качества взаимоотношений с потенциальными потребителями, как на начальном этапе, так и в процессе совершения сделки, зависит итог взаимодействия, который выражается в объеме продаж компании, размере выручки и прибыли от продаж. На размер прибыли предприятия влияет не только ассортимент продукции, ценовая политика, но и коммуникативные навыки того сотрудника, который вступает в процесс активной продажи товара покупателю. На эффективность и качество коммуникации оказывает влияние эмоциональный интеллект - сумма навыков и способностей человека понимать намерения, мотивацию, эмоции и желания не только свои собственные, но и других людей, а также способность управлять эмоциями других людей. Эмоциональный интеллект выступает мерой оценки эффективности решения коммуникативных задач сотрудников, от которых напрямую зависит результат хозяйственной деятельности предприятия. В рамках Международного экономического форума в Санкт-Петербурге в 2019 году на сессии «Компетенции будущего: чему учиться и как учить» участники обсудили 10 наиболее востребованных в корпоративной практике навыков и то, как изменился этот список за последние 5 лет. Так, еще в 2015 году эмоциональный интеллект не входил в перечень ключевых компетенций, а в 2019 году его включили в список наиболее релевантных навыков, помимо комплексного подхода к решению проблем и критического мышления, которые составляют в совокупности 10 самых востребованных компетенций будущего. В связи с 
этим возрастает необходимость исследований эмоционального интеллекта и его влияния на экономику предприятия.

Эволюционный путь научных знаний об эмоциональном интеллекте начался на западе. Основоположниками системы представлений о сущности эмоционального интеллекта являлись Р. Торндайк, Ч. Хант, Д. Векслер, Р. Липер, Р. Лазрус, Л. Шпитц, К. Шерер, У. Гурей, Ф. Данеш, А. Ортони, А. Коллинз, Р. Стенберг, Г. Гарднер, Р. Бар-Он, Дж. Майер, П. Сэловей и Д. Гоулман. В отечественной литературе проблемой эмоционального интеллекта стали заниматься сравнительно позже. Можно выделить труды следующих ученых: С.Л. Рубинштейна, Л.С. Выготского, О.К. Тихомирова, Г.Г. Гарсковой, Е.П. Ильна, М.А. Манойловой, Д.В Люсина, О.О. Марютиной, А.С. Степановой, А.В. Карпова, А.С. Петровской, И.Н. Андреевой. Первая работа на стыке двух систем научных знаний была написана в 2012 году Е.А. Хлевной, кандидатом экономических и психологических наук. В работе «Роль эмоционального интеллекта в эффективности деятельности (на примере руководителей)» была доказана взаимосвязь эмоционального интеллекта руководителей и эффективности результатов их хозяйственной деятельности.

Целью данной монографии является развитие теоретических положений и разработка методических подходов к развитию предприятия на основе уровня эмоционального интеллекта сотрудников.

Достижение поставленной цели исследования обусловливает постановку и предполагает решение следующих задач:

- изучить генезис понятия эмоциональный интеллект и доказать влияние уровня эмоционального интеллекта сотрудников на результаты как их деятельности, так и предприятия;

- провести эмпирические исследования и доказать зависимость экономических результатов деятельности предприятия от эмоционального интеллекта; 
- разработать методические подходы к развитию предприятия с учетом уровня эмоционального интеллекта сотрудников и провести апробацию результатов исследования на предприятии малого бизнеса в сфере торговли легковыми автомобилями ООО «Концепт Кар».

Теоретико-методологической базой исследования послужили работы зарубежных и российских ученых в области эмоционального интеллекта.

Поставленные цели и задачи определили структуру монографии, которая состоит из введения, трех глав, заключения и списка литературы. 


\section{1. СУЩНОСТЬ ПОНЯТИЯ «ЭМОЦИОНАЛЬНЫЙ ИНТЕЛЛЕКТ» И ЕГО РОЛЬ В ДЕЯТЕЛЬНОСТИ ПРЕДПРИЯТИЯ}

\section{1. Эволюция научных знаний об эмоциональном интеллекте}

В человеке всегда присутствовали два начала: рациональное и эмоциональное. Вопрос единства этих, казалось бы, противоположностей и одновременное развитие эмоционального и рационального развивался в рамках различных религиозных и философских учений. Согласно исследованиям [1], первые упоминания о том, что уровень интеллекта оказывает влияние на способности личности контролировать свои эмоции, можно найти в Библии: «долготерпеливый лучше храброго, а владеющий собой лучше завоевателя города» $(16,32)$. Идея связи когнитивного и эффективного начал зародилась в философских и религиозных учениях разных стран. Рассмотрим эти представления. В соответствии с основными постулатами Ветхого Завета, центром духовной и эмоциональной жизни любого человека является сердце. В традициях православия умению понимать и воспитывать свои чувства отводится чуть ли не главенствующая роль, которая пронизывает все учение, начиная с Заповедей: «Возлюби ближнего своего, как самого себя». В данном случае речь идет о любви к людям в целом, невзирая на то, что «кому-то уже пришлось подставить левую щеку после правой».

В традициях католицизма роли интеллекта отводится гораздо большее внимание, чем чувствам. Ведь здесь речь идет о воспитании воли, дисциплине и контроле над низменными желаниями. Протестантизм же, наоборот, всегда популяризировал идеи рационального мышления и практики аскетизма, ведь успешная деятельность человека и, как следствие, его спасение зависели от умения максимально 
контролировать все эмоции [2]. Наряду с религиозным мировоззрением в античные времена развиваются и философские течения, которые положили начало формированию европейской научной мысли о природе и сущности эмоционального интеллекта, но в те времена лишь бытовали рассуждения о главенстве когнитивных процессов над эмоциональными. Платон и Сократ представляли взаимоотношения рационального и чувственного аспектов в подчиненных ролях раба и господина и отмечали важность наличия контроля разума и интеллекта над чувствами [3]. Аристотель внес весомый вклад в развитие представлений человека о характере такой связи. Он занимался исследованием двух сильных эмоций, которые способны как подтолкнуть человека к решительным действиям, которые в итоге приносят положительный исход, так и повлиять на совершение поступков, способных оказать лишь деструктивные последствия - гнев и страх. Суть в том, что Аристотель двоичную систему оценки эмоций перевел в троичную: невозможно в одинаковой степени противопоставить однозначно одно явление другому. Страх, например, вызван чувством приближающегося и неминуемого зла, с другой стороны, страх может содержать в себе и позитивный аспект, например, страх оказаться опозоренным, который предупреждает необдуманные поступки [4]. Аристотель рассуждает о том, что любая эмоция может быть уместна или неуместна, она зависит всегда от конкретных обстоятельств. «Рассердиться может каждый - это легко. Однако выразить гнев в отношении человека, который его заслуживает, в нужной мере, в соответствующее время, для достижения определённой цели и в соответствующей форме - это нелегко», - говорил Аристотель и именно эта его фраза через много веков станет блестящим эпиграфом к всемирно известному труду Дэниэла Гоулмана «Эмоциональный интеллект» [2].

Эмоциональная реакция является результатом субъективной оценки природы катализатора такой реакции. Следовательно, умение давать соответствующую внешним и внутренним факторам субъек- 
тивную оценку стимулов, которые побуждают эмоциональную реакцию, позволяет человеку регулировать интенсивность выражения внешних проявлений своей чувственной стороны или указывает на возможность человека контролировать свои эмоции посредством интеллекта. Аристотель также полагал, что отсутствие эмоций в принципе не есть благость, ведь это лишает человека возможности комфортного существования в мире и социуме, наоборот, умеренность в проявлении эмоций, которая воспитывается путем перманентного главенства когнитивной функции мозга, способна положительно влиять на адаптивность личности. Основные постулаты учения Аристотеля вплоть до XX века развивали стоики, но их определенным шагом назад было убеждение о том, что любая эмоциональная привязанность негативно влияет на человека. Они были убеждены в необходимости освободиться от любого рода таких привязанностей, чтобы познать истинную свободу от низменной социальной действительности и, как следствие, избавиться от негативных чувств и обрести покой. Схоластические учения XIII-XIV вв. провозгласили принцип первичности чувств. В эпоху Просвещения размышлять на тему взаимосвязи когнитивного и эмоционального начал Рене Декарт, который понимал эмоции как один из видов страсти, который берет начало в высших психических центрах - то есть в душе. Он также понимал, что эмоции могут быть дисфункциональными и функциональными. Другой видный деятель этой эпохи Д. Юм ставит под сомнение сам факт существования рассудка, но, тем не менее, подтверждает, что эмоции все-таки способны влиять на когнитивную деятельность сознания. Положил своеобразный конец эпохе Просвещения Жан-Жак Руссо, идеи которого заключались в неограничении эмоций рамками логики. Эти идеи послужили началом расцвета эпохи романтизма, лишенной индифферентности и обезличенной рациональности [5].

В различных системах знаний восточной философии значимость взаимосвязи чувственного и рационального аспектов подчер- 
кивается. Такая взаимосвязь приводит человека к духовности. В практике йоги, например, под развитием интеллекта понимается не освоение новой области знаний и не получение новой информации, а понимание истинного смысла душевных переживаний. Одним из важнейших постулатов и целей буддизма является обретение контроля над эмоциями, чтобы проявлять любые эмоции целесообразно ситуации и в адекватном объеме. В соответствии с философией суфистов, и сердце, и голова являются равноправными признаками развитого интеллекта [2]. Современные философы также подчеркивают актуальность вопроса взаимосвязи эмоционального и рационального. Невозможно добиться эмоциональной устойчивости и, как следствие, успеха без согласованности логики и чувств. Ошо давал следующую оценку: «Всё, что ты знаешь и накапливаешь, - информация, знание, опыт - в то мгновение, когда ты что-то исследовал, покончи с этим. Теперь носить этот мёртвый груз пустых слов, значит раздавить свою жизнь, обременить свою жизнь, помешать самому себе войти в живое, радостное бытие - которое ждёт тебя каждое мгновение» [6].

Вопрос взаимосвязи эмоциональных и когнитивных аспектов, как следует из вышеизложенного материала, становился одним из главных объектов для размышлений и исследований уже на протяжении нескольких десятков веков. Люди пытались оградить рациональность во времена романтизма и целиком отдаться чувствам, но все же ушли от этого. Также они на протяжении эпох целенаправленно исключали фактор эмоционального восприятия мира. Но и такая концепция не получила должного отклика и не задержалась надолго. Исключение эмоционального аспекта из жизни человека не способствует развитию как гуманистического мировоззрения, так и общества в целом. Подавление эмоций ведет к их постепенному вытеснению из сознания человека, что становится источником не только различного рода психологических патологий, но и девиантного поведения, которое наиболее сильно отражается в отсутствии само- 
контроля, что в свою очередь влияет не только на принятие импульсивных решений, но и на эффективную коммуникацию с другими людьми. Общество приняло сам факт наличия прямой связи между головой и сердцем, что одно неизменно влияет на другое и, как следствие, влияет на выбор, который делает человек в той или иной ситуации. Рациональность или иррациональность такого выбора зависит от согласованности чувственного и интеллектуального планов и зависит от огромного количества факторов, которые влияют на восприятие объективной реальности в конкретный момент времени. Исследованиями рациональности и иррациональность экономического поведения занимается активно поведенческая экономика. Сущность выбора тесно связана не только с чувствами, которые возникают, но и с процессом когнитивного анализа катализатора природы чувств. Следовательно, механизм любого выбора, в том числе и принятия управленческих решений, необходимо связывать не только с исключительно эмоциональным или когнитивным аспектом, но и с интеллектуальной обработкой ассоциативного ряда, который формируется как немедленный итог наступления какого-либо события. Результатом такой обработки является проявление эмоций, которые уже служат толчком к совершению действия, например, покупке товара или услуги. Рассмотрев многовековые размышления о природе и взаимосвязи когнитивного и аффективного аспектов, остановимся подробно на понятии «эмоциональный интеллект».

Сущность понятия «эмоциональный интеллект» возникла еще в глубокой древности, вот только как отрасль науки окончательно была оформлена сравнительно недавно, как и, собственно, было дано научное определение явления, которые беспокоило величайшие умы на протяжении долгого времени. Сочетание понятий «эмоции» и «интеллект» само по себе сначала вводило научное сообщество в некое замешательство. По мнению некоторых ученых, уместнее было бы в данном контексте использовать понятие «компетентность», но никак не интеллект, ведь интеллект - это способность и 
никаких особых способностей, которые неразрывно были бы связаны непосредственно с чувствами, не существует [7, 8]. Термин «эмоциональный интеллект» вводился в науку последовательно, поскольку с течением времени изменялось соотношение интеллектуальных и эмоциональных аспектов.

В 1872 году Чарльз Дарвин в работе «Выражение эмоций у человека и животных» писал, что возбуждение разума мгновенно влияет и на сердце, а когда сердце испытывает аналогичное воздействие, оно направляет реакцию в мозг и при возбуждении любого характера из любого источника взаимное воздействие и реагирование между двумя этими важными органами тела неизбежно. Эта дата является своеобразной отправной точкой появления уже научного описания вопроса сосуществования чувств и разума. В зарубежной литературе Дж. Майер выделяет пять периодов в истории исследования эмоционального интеллекта [10]. Рассмотрим каждый из этих периодов.

В первом периоде, который датируется с 1900 по 1969 год, изучение эмоций и интеллекта происходит весьма обособленно. С начала XX века очень бурно развивалась научная деятельность по изучению только интеллекта, в широком смысле логики, - разрабатывались IQ тесты (сокр. от англ. intelligence quotient - коэффициент интеллекта), изучались способы оценки когнитивных способностей человека. Но вопрос, что первично: реакция на событие, то есть эмоция, или физиологический процесс, - уже обсуждался в научных кругах [12]. И на заре XX века уже предпринимались попытки установления связи между аффективными и когнитивными процессами: в 1908 году Г. Майер в работе «Psychologie des emotionalen Denkens» (пер. с нем. - психология эмоционального мышления) особенно выделяет мышление не только логическое, но и эмоциональное, для которого в авангарде стоят воля и потребности чувства [13]. В исследованиях интеллекта изначально такая дифференциация отсутство- 
вала. По мнению М.А. Холодной, одной из двух линий в изучении психологии интеллекта является линия Ч. Спирмена, которая основывается на идее целостности интеллекта. В 1927 году Ч. Спирмен представил двухфакторную модель интеллекта, суть которой была в том, что любые тесты сводились к выявлению фактора g, который и отражает наличие определенного уровня ментальной энергии для решения когнитивных задач [14]. Недостатки теории Ч. Спирмена обусловлены полной автономией интеллекта: уровень интеллекта человека не зависит от его личностных черт. Для характеристики интеллекта в широком смысле слова этого было недостаточно, ведь под интеллектом понимают не только логические способности. Г.Ю. Айзенк разработал тесты на определение коэффициента интеллекта, они широко используются сегодня, интерпретировал фактор g как умственный темп или скорость переработки информации центральной нервной системой [там же]. Кроме тестов Айзенка, повсеместно применяются и «Прогрессивные матрицы» Д. Равена, и тесты интеллекта Р. Кеттела. Через 10 лет с момента публикации работы Ч. Спирмена идея множественности сторон интеллекта все больше утверждается в науке. В 1938 году Л. Терстоун выделяет уже семь базовых умственных потенций в работе «Primary Mental Abilities» (пер. с англ. - первичные умственные способности). Среди них: словесное понимание, речевая беглость, пространственный фактор, ассоциативная память, речевой фактор, индуктивный фактор и скорость восприятия [15]. Однако среди вышеперечисленных первичных умственных способностей едва ли присутствует хоть одна, которая указывала бы на обработку эмоций интеллектом.

Самая ранняя работа, которая оказалась наиболее близка к теме эмоционального интеллекта, была написана в 1920-е гг. Р. Торндайком. Он впервые выделил понятие «социального интеллекта» и определил его как «способность к пониманию других людей и мудрое поведение по отношению к окружающим» [16]. Первые попытки изучить социальный интеллект путем проведения ис- 
следования в виде выявления и идентификации человеком чувства на основе рисунков с различными выражениями эмоций на лице были предприняты в 1930-х гг. Р. Торндайком и Ч. Хантом.

В 1940 году Д. Векслером была написана работа «Неинтеллектуальные факторы в общем интеллекте», в которой он утверждал, что для полной оценки интеллектуального потенциала человека необходимо учитывать и другие стороны мышления, которые не связаны с интеллектом напрямую. Д. Векслер также ввел понятия когнитивных и аффективных умений и разделил умственные способности на невербальные и вербальные, которые в свою очередь могли быть развиты у каждого человека индивидуально [17]. В 1948 году американский ученый Р. Липер впервые выдвинул идею эмоционального мышление и даже разработал первый в своем роде опросник. Основная идея Р. Липера заключалась в том, что в любой логической мысли есть вклад мысли эмоциональной [18]. С 1955 года благодаря исследованиям А. Эллиса в психотерапии эмоции начинают рассматривать под призмой логического анализа. Он разработал рационально-эмотивную терапию, в основе которой лежит утверждение о влиянии на эмоции убеждений, принципов и взглядов человека [19]. В 1960-х гг. впервые в научной литературе появляется термин «эмоциональный интеллект». Причем он не вводится в такую литературу вкупе с определением, он появляется спонтанно в литературной критике [20]. С 1960 по 1970 год развивается направление когнитивистских теорий эмоций. Занимаются развитием этой теории С. Шехтер и М. Арнольд. С. Шехтер выявил, что возникновение эмоций вкупе со стимулом, который такие эмоции порождает, тесно сопряжено и с личным жизненным опытом человека, и с потребностями и интересами, которые превалируют в данный момент. Первый период истории исследования эмоционального интеллекта завершается и начинается второй период, который длится с 1970 по 1989 год. С 1970 до конца 1980 г. интерес научного сообщества к изучению связи эмоций и мышления неуклонно растет [44]. Идея о взаимодействии ког- 
нитивных и эмоциональных процессов прослеживается во многих работах того времени. Изучались интересные взаимосвязи, как то: как депрессия способна повлиять на реалистичность мышления, связана ли креативность человека с постоянными перепадами настроения и так далее. В это время исследованием взаимосвязи когнитивных и аффективных процессов занимаются Р. Лазрус, Л. Шпитц, К. Шерер, У. Гурей, Ф. Данеш, А. Ортони, А. Коллинз и другие. Эмоции исследуют уже в рамках когнитивной психологии, которая стала развиваться в 1960-е гг. в связи с распространением кибернетики и появлением возможности электронного моделирования некоторых интеллектуальных процессов. Человека стали представлять в качестве биомашины, ученые пытались смоделировать все процессы, которые происходили в человеке, те из них, которые смоделировать посредством ЭВМ получилось, назвали когнитивными (поскольку они обладали логичной и осмысленной последовательностью действий). Эмоции рассматривались как функция разума, подсистема сознания, фундамент для основных структур сознания [22]. Социальный интеллект, о котором говорилось ранее, не выходит из сферы научных интересов психологов, в его структуре начинают выделять отдельно социальную тревожность, чувствительность и эмпатию. Определение эмоционального интеллекта еще не было введено. Его внедрению в область психологического знания способствовали исследования в смежных науках: с помощью искусственного интеллекта изучалась возможность компьютера объяснять и интерпретировать расстановку эмоциональных акцентов в повествовании, создавались различные методики для изучения невербальной информации и так далее. Идеи Л. Терстоуна о семи основных умственных потенциях получили дальнейшее развитие спустя сорок лет после публикации. Х. Гарднер в 1983 году предположил о существовании различных интеллектуальных способностей, среди которых были и интрапсихические (способность к самонаблюдению). Он выделил семь форм интеллекта: телесно-кинестетический, внутрилич- 
ностный, логико-математический, лингвистический, музыкальный, межличностный и пространственный [23]. Важность данного исследования заключается в том, что каждая из этих способностей служит для достижения успеха в определенной сфере жизнедеятельности человека. Каждый компонент интеллекта представляет ценность, которая определяется в первую очередь нормами, которые установлены в обществе.

Исследования Д. Векслера и Р. Липера продолжил и развил Р. Стенберг, который предложил концепцию «практического интеллекта». Р. Стенберг определил его как способность к адаптации или изменению ситуации, которая возникла в реальной жизни [24]. В широком смысле Р. Стенберг сосредоточился на изучении интеллекта как системы, которая служит приспособлению человека к окружающему миру. Интеллект определяют как вид умственной саморегуляции, которая содержит три элемента: адаптивность к окружающему миру, селекцию среды, которая максимально совместима с индивидом, и само формирование такой среды. В теории триединства Р. Стенберга связь интеллекта устанавливалась с тремя процессами, которые происходят в жизни человека: внутренние процессы, опыт и взаимодействие с внешней средой. В 1983 году Г. Гарднер отдельно выделяет «межличностный интеллект» в своей модели. Он определяет межличностный интеллект как способность прогнозировать поведение людей, основываясь на наблюдении за выражением их чувств [28]. В 1985 году Р. Бар-Он впервые вводит понятие «коэффициент эмоциональности» и разрабатывает анкету для его измерения. И уже в 1986 году в диссертации В.Л. Пейна термин эмоциональный интеллект был впервые употреблен [25]. По мнению И. Андреевой, предпосылками смешанных моделей эмоционального интеллекта были: концепция самоэффективности А. Бандуры, А. Маслоу с теорией самоактуализации. В этих работах умение осознавать свои способности, эффективно управлять поведением в соответствии со своими сильными и слабыми сторонами выходит на 
первый план. Дж. Майер и П. Сэловей в одной из статей, которые предшествовали появлению концепции эмоционального интеллекта, выдвинули предположение, что на познание оказывают влияние эмоциональные явления, которые можно регулировать. Они указали, что существует некий комплекс особенностей, которые индивидуальны для каждого человека и которые отвечают за то, какое именно влияние окажут эмоциональные явления на человека: конструктивное или деструктивное. Открытие нового вида интеллекта было достаточно близко. Оставалось соединить разрозненные исследования, которые лишь косвенно указывали на существование эмоционального интеллекта, и дать определение новому термину. Вместе с этим было необходимо предоставить эмпирические доказательства существования эмоционального интеллекта и объяснить его природу.

В 1990 году начался третий период истории развития эмоционального интеллекта, когда Дж. Майер и П. Сэловей впервые опубликовали исследование, посвященное эмоциональному интеллекту, в котором они дали определение термину и предложили методику, согласно которой можно измерить уровень эмоционального интеллекта (EQ). Они доказали, что эмоциональный интеллект по праву можно считать еще одним из видов интеллекта. Дж. Майер и П. Сэловей определили эмоциональный интеллект как способность к идентификации собственных эмоций и эмоций окружающих людей и дальнейшее использование этой информации для принятия решений [9]. С момента появления данной публикации начался период проведения серьезных эмпирических исследований в данной области. Феномен эмоционального интеллекта стал необычайно популярен, а интерес к этой области психологии возрос многократно, и исследуемые границы заметно расширились, что послужило началом четвертого периода становления эмоционального интеллекта как области знания. Также начало четвертого периода связывают с выходом в 1995 году книги Дэниэла Гоулмана «Эмоциональный интеллект», которая мгновенно стала бестселлером и положила начало 
популяризации нового вида интеллекта. Д. Гоулман показал, что особое внимание к эмоциональному интеллекту важно для ведения бизнеса. Ведь эмоции особенно сильно влияли на бизнес еще со времен средневековой Европы, когда под влиянием настроения любая сделка, даже самая выгодная, могла быть сорвана. Приемлемыми нормами поведения в то время считались оскорбления, драки, обман. Лишь с течением времени люди осознали, что необходимо создавать позитивный имидж и что негативные эмоции не должны влиять на деловые отношения. Люди стали скрывать их, они научились вести дела сухо, руководствуясь исключительно логикой. И обман стал более изощрённым, вот почему умение анализировать не только свои эмоции, но и внешнее проявление эмоций другого человека и умение их распознавать может уберечь предпринимателей и потребителей от совершения ошибок.

С 1998 года начался пятый период, который продолжается до сих пор. Сегодня выдвигаются теории о способах совершенствования существующей концепции эмоционального интеллекта, предлагаются новые методы его измерения. Начали выходить первые рецензированные научные статьи. Распространено мнение, что исследования в области эмоционального интеллекта проводить довольно сложно, потому что популистские представления о сущности этого понятия, методах его измерения, которые навязали маркетологи и различные бизнес-тренеры, далеки от научной парадигмы. По мнению основателя концепции эмоционального интеллекта Дж. Майера, есть два вида эмоционального интеллекта: первый - «популярный» эмоциональный интеллект, который можно быстро приобрести и развить и который является неоспоримым фактором достижения успеха, а второй эмоциональный интеллект - это научный феномен [29]. Как видно из представленного материала, эмоциональный интеллект за рубежом рассматривался, в основном, в сфере психологии, психиатрии и социологии. Были попытки во время бурного развития когнитивной психологии, проводить исследования эмоционального ин- 
теллекта с использованием интеллекта искусственного, но, опять же, вопросы, которые выносились на исследование, были связаны с психофизическими процессами. Эмоциональный интеллект и его связь с экономической наукой исследуются сравнительно недавно. В начале 1990-х гг. с момента появления этого понятия никто не задумывался о том, а какой может быть экономический эффект, если применить знания об эмоциональном интеллекте не только в психологии, но и в экономике и менеджменте. Рассмотрим современные точки зрения о связи эмоций и экономики, которые превалируют за рубежом.

В современной литературе, безусловно, отмечается, что эмоции оказывают влияние на экономику, потому что они либо помогают человеку выполнять определённую экономическую роль посредством управления эмоциями или увеличения уровня эмоционального интеллекта, либо потому что способствуют рациональному выбору посредством влияния на формирование предпочтений. Все эти направления исследуют связь между эмоциями и экономикой с точки зрения отдельно взятого индивидуума. Но есть и другой подход, который основывается на эмоциональной вовлеченности и изучает степень влияния эмоций на экономическое взаимодействие. Результаты исследований эмоциональной вовлеченности говорят о том, что эмоции возникают в результате взаимодействия между экономическими акторами в ходе процесса, где эмоциональные потоки и их интуитивные и физические проявления выходят на первый план. Это увеличивает неопределенность исхода экономических операций и усложняет принятую научным обществом логику о рациональном принятии решений, которая, в конце концов, уступает место другим принципам экономического поведения, которые могут отличаться от теории максимизации полезности. В зарубежной литературе описывают два вида таких экономических действий: импровизация или ситуационная адаптация. Импровизация характеризует ситуации, когда цели и средства в начале процесса экономического взаимодействия неясны и с ростом эмоциональной вовлеченности постепенно опре- 
деляются уже в ходе совершения такого действия. Ситуационная же адаптация возникает тогда, когда конечная цель экономического актора меняется в процессе из-за вмешательства различного рода эмоций, которые вынуждают актора поменять изначально принятую концепцию и желаемые вероятности исхода экономического взаимодействия. Исследованием влияния эмоций на экономические результаты, экономическое поведение акторов занимались с середины $\mathrm{XX}$ века, но про взаимосвязь эмоционального интеллекта и экономических результатов писали в основном с точки зрения изучения феноменов лидерства и эффективности работы компании [30]. Тем не менее можно предположить, что раз влияние эмоций на экономическое поведение уже доказано эмпирически, то, соответственно, и уровень эмоционального интеллекта как основной детерминант силы, посыла, истока формирования эмоций воздействует на экономическое поведение.

Рассмотрим развитие идеи эмоционального интеллекта в отечественной науке. Начал изучать это понятие в 1930-х гг. Л.С. Выготский. Он первый выдвинул предположение о том, что необходимо изучать взаимосвязь когнитивных и аффективных процессов и что развитие эмоций идет всегда параллельно с развитием мышления, более того, он выдвинул предположение, что эмоция является составной частью мышления в целом [31]. Его идеи развил А.Н. Леонтьев. Он писал, что необходимо различать объективное значение и значение этого объективного для отдельной личности. А.Н. Леонтьев показал, что мышление может иметь аффективную регуляцию [32]. Примерно такого же мнения был и другой ученый С.Л. Рубинштейн. Но С.Л. Рубинштейн, хоть и был сторонником идей, которые уже развивались Л.С. Выготским, «предвосхитил» появление самой идеи эмоционального интеллекта, заявив, что речь идет не только о том, что интеллект и эмоции едины, но и о единстве внутри самих эмоций и внутри самого интеллекта аффективного и когнитивного [33]. Стоит отметить работы Б.В. Зайгарник, которая говорила о том, что без оп- 
ределенных установок, мотивов, чувств человека мышление просто не может существовать. Она также развивает идею Л.С. Выготского, что мысль берет начало из мотивации, которая возникает из совокупности потребностей, интересов и побуждений, а не является конечным продуктом предыдущей мысли. Определенные события, которые происходят с человеком на протяжении жизни, могут в различных условиях иметь диаметрально противоположный смысл и эмоциональную окраску, хотя сама система когнитивных представлений и имеющихся знаний о происходящем событии остается неизменной. Эмоции могут повлиять на изменения значения предметов [34]. О.К. Тихомиров внедрил понятие эмоционального мышления, которое, по мнению многих ученых, наиболее близко было по своей сути к понятию эмоционального интеллекта. Изучая природу эмоционального мышления, О.К. Тихомиров отмечал, что в процесс решения многих задач, которые стоят перед человеком, неизбежно включены и различные эмоциональные состояния. Мыслительная деятельность связана напрямую со всеми эмоциональными явлениями [35]. Исследования О.К. Тихомирова убедили научное сообщество в том, что мыслительная деятельность регулируется эмоциями и что для продуктивной интеллектуальной деятельности человеку необходима и эмоциональная активизация.

Так же, как и за рубежом, в современной литературе занимаются изучением эмоциональности и того, как отдельные эмоции могут влиять на успешность человека, принятие управленческих решений и укрепление позиции лидера. Работы в этом направлении ведут И.В. Пацявичус, И.А. Переверзева, О.П. Санникова и другие. Вопросами взаимодействия когнитивных и аффективных процессов занимался А.В. Брушилинский. Он считал, что эмоции могут не только способствовать мышлению, но и препятствовать ему. Он особенно выделял роль эмоций в оценке предметов и событий, а оценочная деятельность человека является одним из важных компонентов мыслительной деятельности [36]. А.А. Бодалев также внес в изучение 
феномена эмоционального интеллекта свой вклад: он считал, что существуют такие люди, которые совмещают в себе определенные интеллектуальные, эмоциональные и коммуникативные способности, что в итоге делает таких людей успешными и влияет на уровень коммуникации с другими людьми.

Г.Г. Гарскова в конце 90-х гг. написала одну из первых работ, где было сформулировано определение эмоционального интеллекта уже в отечественной литературе. Установлена связь между способностью понимать других людей и эмоциональным интеллектом, благодаря чему у человека есть возможность управлять эмоциями на основе интеллектуального анализа и синтеза [39]. В СанктПетербурге в 2001 году было выпущено учебное пособие «Эмоции и чувства» под авторством Е.П. Ильина. В этом пособии были проанализированы все определения и формулировки, которые представили западные ученые, и предложено более общее определение эмоционального интеллекта как «эмоционально-интеллектуальной деятельности» [40]. В 2004 г. уже появляется труд Д.В. Люсина, О.О. Марютина и А.С. Степанова «Социальный интеллект», в котором указано, что эмоциональный интеллект - это способность к пониманию своих и чужих эмоций и управление ими [41]. Также в 2004 году М.А. Манойлова определяет этот феномен как способность к осознанию, принятию и регуляции эмоциональных состояний и чувств других людей и себя самого [42]. В 2008 году А.В. Карпов и А.С. Петровская в монографии «Психология эмоционального интеллекта» проанализировали современное состояние проблемы этого феномена и предложили свои методики измерения уровня эмоционального интеллекта. В определение они включают «способность к осознанию, пониманию эмоций и управлению ими» [43]. Особое внимание хочется уделить работам и исследованиям И.Н. Андреевой, о которой неоднократно уже упоминалось в этой работе, в частности ее монографии «Эмоциональный интеллект как феномен современной психологии», которая вышла в 2011 году. В этой работе И.Н. Андреева 
рассмотрела различные модели эмоционального интеллекта, она также на основании эмпирических исследований доказала, что существуют гендерные различия в этой сфере. С точки зрения И.Н. Андреевой, эмоциональный интеллект - это совокупность ментальных способностей к идентификации, пониманию и управлению эмоциями [2]. Об интересе к этому феномену и проведении серьезной научной работы также говорит тот факт, что за последние годы было написано много научных работ и защищены десятки диссертаций (К.С. Кузнецова (2012), Н.С. Синельникова (2015), Ю.В. Давыдова (2011), Е.А. Хлевная (2012), Л.Д. Камышникова (2012), Т.С. Киселева (2015) и другие) [38].

Исследование взаимосвязи эмоционального интеллекта и эффективности деятельности руководителей было проведено Е.А. Хлевной в работе «Роль эмоционального интеллекта в эффективности деятельности (на примере руководителей)». Это была первая работа, в которой удалось выявить и описать взаимосвязь уровня эмоционального интеллекта руководителя с эффективностью его деятельности [44]. Во всех научных работах эмоциональный интеллект рассматривался больше с точки зрения управления персоналом. Начиная с 2013 года, появляется несколько работ в сфере формирования интеллектуального капитала, но феномен эмоционального интеллекта обозначен неявно, а лишь вскользь упоминается. В 2016 году Н.А. Перепёлкин защитил диссертацию на тему «Развитие событийного маркетинга в российских компаниях», где он отмечает, что наиболее успешными являются те компании, которые обращаются к психологии потребителя. Также он отметил возрастающую роль эмоционального интеллекта в управленческой и других областях деятельности организации [45].

Явление эмоционального интеллекта не ново для отечественной науки. Его заметили достаточно давно, но на протяжении долгого времени это явление носило разные имена: «обобщение пережи- 
ваний», «эмоциональное мышление», «смысловое переживание» и так далее. Стоит отметить, то все вышеперечисленные термины не являются вариацией или производной от эмоционального интеллекта. Вводить новую категорию, по мнению отечественных ученых, был смысл, потому что все ранее существовавшие концепции и объяснения пришли к «общему знаменателю», имеют наиболее сильную эмпирическую базу и «объясняющую силу» [37]. Описав эволюцию изучения феномена эмоционального интеллекта, можно сделать следующие выводы:

- понятие «эмоциональный интеллект» было представлено научному сообществу после долгого периода изучения взаимосвязей между аффективными и когнитивными процессами;

- феномен эмоционального интеллекта продолжают изучать и проводить эмпирические исследования в смежных науках;

- на западе изучению эмоционального интеллекта уделяют гораздо больше внимания;

- в отечественной науке считается, что вопрос эмоционального интеллекта до сих пор проработан недостаточно;

- влияние эмоционального интеллекта на успешность деятельности руководителей (сравнивался уровень эмоционального интеллекта и эффективность работы предприятия), высокую успеваемость школьников и студентов (сравнение эмоционального интеллекта с успеваемостью), карьерный рост и эффективное взаимодействие с окружающими людьми уже было эмпирически обосновано в исследованиях Дж. Майера, П. Квальтер, Е. Хлевной.

Научных определений эмоционального интеллекта немного, но общепринятым в науке на сегодня является определение Дж. Майера. Хотелось бы кратко указать не только на успехи и значимость этого феномена, но и на проблемы и узкие места в теории, которые сейчас научное сообщество пытается разрешить. Во-первых, в попу- 
листских источниках эмоциональный интеллект предстает как верный рецепт достижения успеха во всех сферах жизни, но, по мнению Дж. Майера, исключительно по уровню высокого эмоционального интеллекта невозможно дать гарантию, что человек через какой-то период времени возглавит транснациональную корпорацию. Дэниэл Гоулман, несмотря на его огромный вклад в популяризацию этого феномена, стал объектом критики из-за нехватки в его исследованиях научного и системного подхода, коммерциализации феномена и практически полном отсутствии ссылок на источники. Стоит отметить и критику моделей эмоционального интеллекта. По мнению ученых, в такие модели можно произвольно добавлять или убирать некоторые компоненты. Нет сомнений, что любой компонент феномена эмоционального интеллекта влияет на успех деятельности человека, особенно в карьере и управлении, тем не менее четкий и научный принцип, на основе которого можно было бы структурировать это понятие и методы его определения, просто необходим для подачи этого феномена как научной теории. В противном случае может получиться лишь бессистемный набор факторов, который был выбран произвольно и который не находится в строгих рамках научной теории [46]. В таблице 1 приведены различные понятия эмоционального интеллекта.

Таблица 1.

Генезис понятия «эмоциональный интеллект»

\begin{tabular}{|l|l|}
\hline \multicolumn{1}{|c|}{ Автор } & \multicolumn{1}{|c|}{ Определение } \\
\hline $\begin{array}{l}\text { П. Сэловей, } \\
\text { Дж. Мэйер [48] }\end{array}$ & $\begin{array}{l}\text { способность отслеживать собственные и чужие чув- } \\
\text { ства, эмоции, различать их и использовать эту ин- } \\
\text { формацию для направления мышления и действий }\end{array}$ \\
\hline Д. Гоулман [75] & $\begin{array}{l}\text { способность человека истолковывать собственные } \\
\text { эмоции и эмоции окружающих с тем, чтобы ис- } \\
\text { пользовать полученную информацию для реализа- } \\
\text { ции собственных целей }\end{array}$ \\
\hline
\end{tabular}


Окончание Таблицы 1.

\begin{tabular}{|l|l|}
\hline Р. Бар-Он [18] & $\begin{array}{l}\text { все некогнитивные способности, знания и компе- } \\
\text { тентность, дающие человеку возможность успеш- } \\
\text { но справляться с различными жизненными ситуа- } \\
\text { циями }\end{array}$ \\
\hline И.Н. Андреева [2] & $\begin{array}{l}\text { устойчивая ментальная способность, часть обшир- } \\
\text { ного класса ментальных способностей и подструк- } \\
\text { тура социального интеллекта в структуру которой } \\
\text { входят: во-первых, способности к осознанию регу- } \\
\text { ляции эмоций; во-вторых, понимание эмоций; } \\
\text { в-третьих, ассимиляция эмоций в мышлении, и край- } \\
\text { ний компонент различение и выражение эмоций }\end{array}$ \\
\hline Д.В. Люсин [52] & $\begin{array}{l}\text { психологическое образование, формирующееся } \\
\text { в ходе жизни человека под влиянием ряда факто- } \\
\text { ров, которые обуславливают его уровень и специ- } \\
\text { фические индивидуальные особенности }\end{array}$ \\
\hline $\begin{array}{l}\text { М.А. Манойло- } \\
\text { ва [42] }\end{array}$ & $\begin{array}{l}\text { способность человека к осознанию, принятию и } \\
\text { регуляции эмоциональных состояний и чувств } \\
\text { других людей и себя самого }\end{array}$ \\
\hline $\begin{array}{l}\text { А.В. Карпов, } \\
\text { А.С. Петров- } \\
\text { ская [43] }\end{array}$ & $\begin{array}{l}\text { результативное проявление системы метапроцес- } \\
\text { суаных процессов личности }\end{array}$ \\
\hline
\end{tabular}

Определение, которое наиболее полно раскрывает сущность понятия, принадлежит авторству И.В. Андреевой, что эмоциональный интеллект - это совокупность ментальных способностей к идентификации, пониманию и управлению эмоциями. Методы измерения эмоционального интеллекта, области деятельности, на которые эмоциональный интеллект влияет, из каких именно показателей складывается уровень эмоционального интеллекта, будет рассмотрено подробно в следующем разделе диссертации. 


\section{2. Модель и структура эмоционального интеллекта}

Несмотря на то, что существует достаточно много работ, которые посвящены изучению эмоционального интеллекта, и во многих из них есть авторские трактовки понятия, все теории можно отнести к двум группам.

Дж. Майер, П. Сэловей и Д. Карузо отдельно выделили «модели способностей», где эмоциональный интеллект рассматривается в когнитивном аспекте, и «смешанные модели», в которых посредством комбинации личностных характеристик и когнитивных способностей и формируется эмоциональный интеллект. К.В. Петридес и Э. Фернхем предложили еще одно разделение концепций эмоционального интеллекта на классы: «как черта» и «как способность». Эти классы различаются методикой изменения уровня эмоционального интеллекта. Эмоциональный интеллект «как черта» определяется при помощи опросников, а «как способность»- тестами [31].

Рассмотрим четыре основных модели, которые наиболее часто используются при оценке эмоционального интеллекта. Первая модель - это модель Питера Сэловея, Джона Майера и Дэвида Карузо. По мнению этих авторов, эмоциональный интеллект - это конгломерация умственных способностей, которые способствуют осознанию и понимаю собственных эмоций и эмоций окружающих [47].

В 1990 году Дж. Мейер и П. Сэловей представили структуру эмоционального интеллекта (таблица 2) [2]. Она наиболее распространена в литературе на тему исследований эмоционального интеллекта. 
Таблица 2.

Структура эмоционального интеллекта по Дж. Майеру и П. Сэловею

\begin{tabular}{|l|l|l|}
\hline \multicolumn{1}{|c|}{\begin{tabular}{c}
\multicolumn{1}{c|}{ Идентификация и } \\
выражение эмоций
\end{tabular}} & \multicolumn{1}{c|}{$\begin{array}{c}\text { Регуляция } \\
\text { эмоций }\end{array}$} & $\begin{array}{c}\text { Использование эмоций } \\
\text { в мышлении и } \\
\text { деятельности }\end{array}$ \\
\hline $\begin{array}{l}\text { Собственных (вербальное } \\
\text { или невербальное); } \\
\begin{array}{l}\text { Других людей (невербаль- } \\
\text { ное восприятие) }\end{array}\end{array}$ & $\begin{array}{l}\text { Собственных; } \\
\text { Других людей }\end{array}$ & $\begin{array}{l}\text { Гибкое планирование; } \\
\text { Творческое мышление; } \\
\text { Переключение внимания; } \\
\end{array}$ \\
\hline
\end{tabular}

Согласно таблице выше, эмоциональный интеллект согласно представлениям авторов, включил три типа способностей: регуляция эмоций, идентификация и выражение эмоций и использование эмоций в мышлении и деятельности. Каждый тип способности в свою очередь состоял из нескольких элементов. Также авторы в той структуре, которая была представлена выше, определяли два глобальных подтипа: внутриличностный и межличностный эмоциональный интеллект. Внутриличностный эмоциональный интеллект показывает, насколько человек способен отслеживать и устанавливать связи между своими поступками, чувствами и мыслями, а межличностный - умение приспосабливаться к поведению других людей, сопереживать, вдохновлять, мотивировать. Внутриличностный эмоциональный интеллект позволял человеку комфортно уживаться самому с собой, а межличностный отвечал за эффективность коммуникации в обществе. Основные принципы теории Дж. Майера и П. Сэловея основывались на таких качествах, как эмпатия, равновесие, ответственность и осведомленность [47]. Эмпатия заключается в умении идентифицировать себя с чувствами других людей, осведомленность - способность отслеживать собственные чувства и 
эмоции и различать конструктивные и деструктивные, равновесие помогает человеку уравновешивать функционирование двух полушарий мозга. Ответственность заключается в том, что человек способен отвечать за свое благополучие. Эмоции порой способны оказывать влияние на череду выборов в жизни человека, и высокий уровень эмоционального интеллекта призван контролировать те решения, которые принимает человек, пусть и под воздействием эмоций.

Трехкомпонентная структура была переработана позже в 2000 году. В ее основу включили возможную информацию о содержании в эмоциях связей индивидуума с предметами или людьми. Вследствие изменения базовых представлений, под эмоциональным интеллектом понималась способность человека к переработке той информации, которая содержится в эмоциях. Вместо трехкомпонентной модели была разработана структура из четырех ветвей, каждая из которых относилась к эмоциям собственным и других людей [48].

Первая ветвь - различие (идентификация) и выражение эмоций. Она включает способности к идентификации и восприятию эмоций, адекватному выражению, умению различать подлинную реакцию или ее имитацию по невербальным признакам. Вторая ветвь - это фасилитация мышления или ассимиляция эмоций в мышлении. Фасилитация мышления указывает на возможность человека использовать эмоциональные колебания в качестве средства анализа различных точек зрения при работе с конкретной задачей. Некоторым типам решений проблем и задач, например, в контексте управления планированием, способствует определенный перечень эмоций [49, 50]. Понимание и осмысление эмоций, которые определяют уровень человека в мастерстве видеть взаимосвязи между эмоциями, отслеживать их причины и моменты перехода от одной к другой, является третьей ветвью в концепции. Четвертая и последняя ветвь - осознанная регуляций эмоций. Способность контролировать эмоции, снижать силу отрицательных, культивировать положительные, 
склонность к разрешению собственных эмоциональных проблем, не используя принцип простого подавления отрицательных эмоций.

Четвертая ветвь тесно связана с вопросами проактивности и личной эффективности. Ведь уровень владения этими качествами определяет успешность и согласованность Я-концепции человека, качество постановки личных целей и следование им. Все компоненты, которые были перечислены, выстраиваются в четкую иерархию, уровни которой в онтогенезе осваиваются последовательно и идут от простых в освоении к сложным. Порядок всех четырех ветвей определяется той степенью, в которой описываемая способность встраивается в психологические подсистемы личности. Наглядно представим взаимосвязи эмоционального интеллекта в таблице 3 [2].

Таблица 3.

Четырехкомпонентная модель эмоционального интеллекта и её взаимосвязи с общим интеллектом и индивидуальностью

\begin{tabular}{|l|l|l|}
\hline $\begin{array}{c}\text { Компонент } \\
\text { модели }\end{array}$ & \multicolumn{1}{|c|}{ Описание измерений } & \multicolumn{1}{c|}{$\begin{array}{c}\text { Взаимосвязь } \\
\text { с интеллектом } \\
\text { и индивидуальностью }\end{array}$} \\
\hline $\begin{array}{l}\text { Управление } \\
\text { эмоциями }\end{array}$ & $\begin{array}{l}\text { Способность управлять эмо- } \\
\text { циями и эмоциональная } \\
\text { взаимосвязь с личным и } \\
\text { межличностным ростом }\end{array}$ & $\begin{array}{l}\text { Взаимодействие между } \\
\text { человеком и его целями }\end{array}$ \\
\hline $\begin{array}{l}\text { Пмнимание } \\
\text { эмоций }\end{array}$ & $\begin{array}{l}\text { Способность осмысливать } \\
\text { эмоциональную информацию } \\
\text { о взаимосвязях одной эмоции } \\
\text { и другой, умение восприни- } \\
\text { мать лингвистическую ин- } \\
\text { формацию об эмоциях }\end{array}$ & $\begin{array}{l}\text { Центральная позиция } \\
\text { абстрактной обработки } \\
\text { эмоциях и эмоциональ- } \\
\text { ной информации }\end{array}$ \\
& \multicolumn{2}{|l}{} \\
\hline
\end{tabular}


Окончание Таблицы 3.

\begin{tabular}{|l|l|l|}
\hline $\begin{array}{l}\text { Фасилитация } \\
\text { мышления }\end{array}$ & $\begin{array}{l}\text { Способность использовать } \\
\text { информацию об эмоциях для } \\
\text { повышения личной эффек- } \\
\text { тивности }\end{array}$ & $\begin{array}{l}\text { Регулирование исполь- } \\
\text { зования эмоциональной } \\
\text { информации для реше- } \\
\text { ния когнитивных задач }\end{array}$ \\
\hline $\begin{array}{l}\text { Различение } \\
\text { эмоций }\end{array}$ & $\begin{array}{l}\text { Способность определять } \\
\text { эмоции по лицу, на изобра- } \\
\text { жении }\end{array}$ & $\begin{array}{l}\text { Ввод информации к ин- } \\
\text { теллекту }\end{array}$ \\
\hline
\end{tabular}

Модель из четырех компонентов (ветвей) получила название круговой модели (рисунок 1).

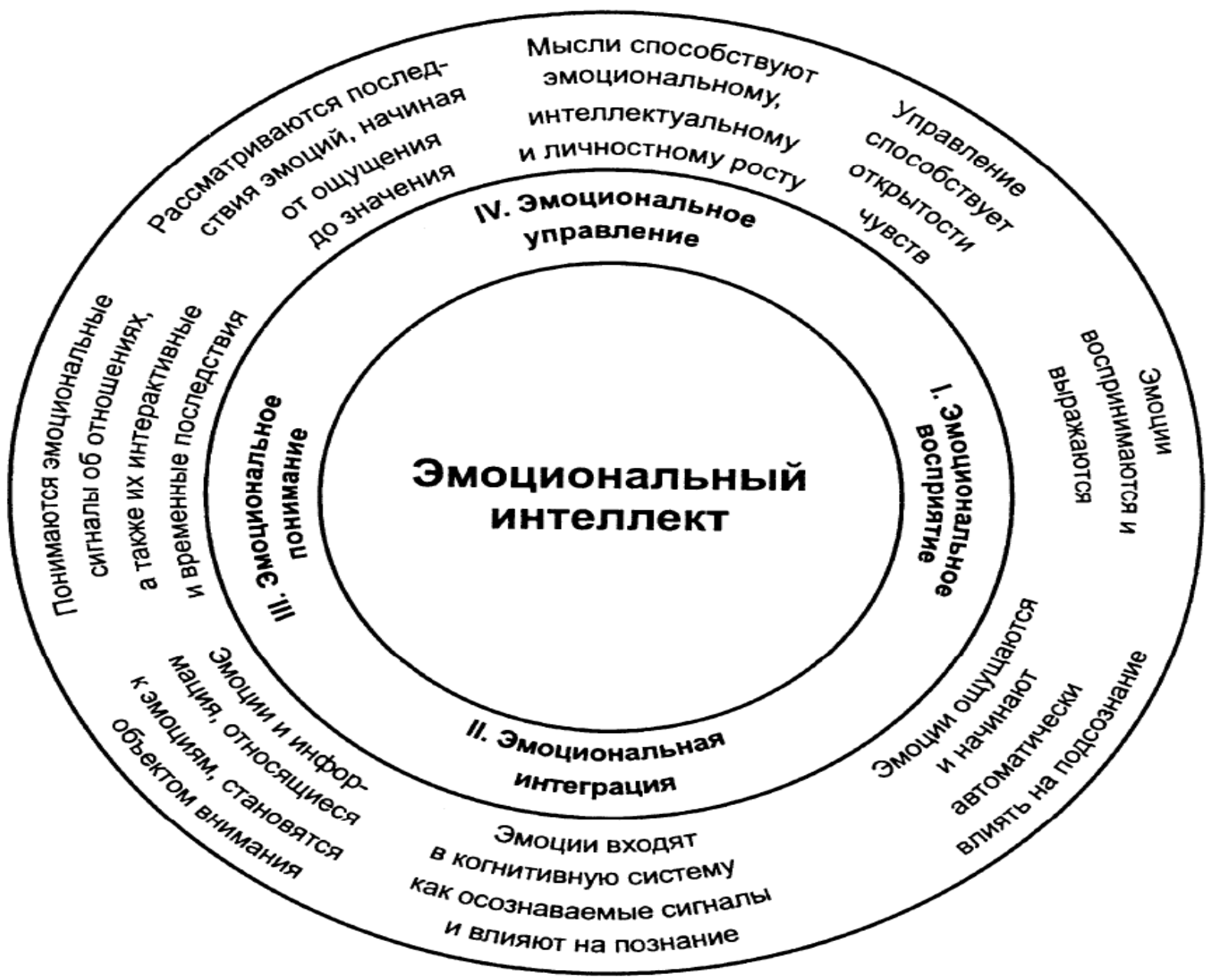

Рисунок 1. Круговая модель эмоционального интеллекта Дж. Мейера, П. Сэловея и Д. Карузо 
На основании теории эмоционального интеллекта Дж. Мейера, П. Сэловея и Д. Карузо в 2002 году был создан тест MSCEIT V2.0 (Mayer-Salovey-Caruso Emotional Intelligence Test), который является наиболее известной методикой определения уровня эмоционального интеллекта, основанный на достаточной эмпирической базе. Для анализа уровня эмоционального интеллекта описанные выше способности объединены в четыре тестовых блока по два субтеста в каждом. Респонденту нужно выбрать верный на его взгляд ответ. Ему предлагается оценить вероятностные эмоции людей на различных изображениях и дать ответы на ряд вопросов с различными вариантами ответов.

Для оценки правильности выбранного тестируемым варианта используются: экспертные мнения, принцип большинства, точка зрения самих разработчиков тестовых заданий и актеров или художников, которые имитировали или создавали определенные эмоции. Основным недостатком этого метода является отсутствие валидных ключей к тесту, что ставит под вопрос методику подсчета итоговых балов. MSCEIT тест обеспечивает удовлетворительно надежное и разностороннее измерение уровня эмоционального интеллекта. Он является наиболее проработанным (и не так давно) Институтом психологии РАН была проведена процедура адаптации к русскоязычному варианту [51].

Рассмотрим модель Дэниэла Гоулмана. Она так же представляет собой определенную иерархию и предполагает, что те эмоции, которые были идентифицированы, могут быть и управляемы. Другим аспектом управления эмоциями является возможность культивировать положительные эмоции, которые способны привести к успеху и элиминировать отрицательные и деструктивные эмоции, которые могут поставить под вопрос достижение плановых целей и задач не только в личной жизни, но и в рабочей среде. Модель Д. Гоулмана состоит из четырех компонентов: социальное понимание и управле- 
ние взаимоотношениями, самосознание и самоконтроль. Стоит отметить, что для разных категорий эта модель несколько различается: способности, которые необходимо развивать преподавателям и те, которые больше подходят для лидеров, в большинстве случаев тех, кто занимает руководящие должности и управляет деятельностью предприятия. Сосредоточимся на той, которая была разработана для оценки эмоционального интеллекта лидеров. Рассмотрим данную модель в таблице 4.

Таблица 4.

Модель эмоционального интеллекта Дэниэла Гоулмана

\begin{tabular}{|c|c|}
\hline $\begin{array}{l}\text { Самосознание } \\
\text { - эмоциональное самосознание } \\
\text { (анализ собственных эмоций и ре- } \\
\text { зультат их воздействия, при приня- } \\
\text { тии решений возможно использо- } \\
\text { вание интуиции) } \\
\text { - точная самооценка (осознание } \\
\text { слабых и сильных сторон, предела } \\
\text { возможностей) } \\
\text { - уверенность в себе (адекватная } \\
\text { оценка таланов и чувства собствен- } \\
\text { ного достоинства) }\end{array}$ & \begin{tabular}{l}
\multicolumn{1}{c}{ Социальная чуткость } \\
- сопереживание \\
- деловая осведомленность (пони- \\
мание иерархии, ответственности и \\
событий на организационном \\
уровне) \\
- предупредительность (умение \\
удовлетворять потребности поку- \\
пателей, клиентов и подчинённых)
\end{tabular} \\
\hline \begin{tabular}{l}
\multicolumn{1}{c}{ Самоконтроль } \\
- обуздание эмоций (контроль де- \\
структивных эмоций) \\
- открытость (честность, прямота) \\
- адаптивность
\end{tabular} & $\begin{array}{l}\text { Управление отношениями } \\
\text { - воодушевление (по отношению } \\
\text { к другим) } \\
\text { - влияние (способность убеждать) } \\
\text { - помощь в самосовершенствова- } \\
\text { нии (уметь поддержать и напра- } \\
\text { вить людей с помощью советов и } \\
\text { наставлений) }\end{array}$ \\
\hline
\end{tabular}


Окончание Таблицы 4.

- воля к победе (настойчивость, стремление улучшить производительность для того чтобы соответствовать внутренним представлениям о стандартах качества)

- инициативность

- оптимизм
- содействие изменениям (умение вести за собой в период изменений и инициировать эти изменений)

- урегулирование конфликтов

- укрепление личных взаимоотношений

- командная работа и сотрудничество

Видно невооруженным глазом, насколько модель Д. Гоулмана более расширена по сравнению с моделью MSC (Майера - Сэловея Карузо). Д. Гоулман добавил больше социальных навыков, и в его модели когнитивные способности и личные характеристики были соединены.

Методика определения уровня эмоционального интеллекта по Д. Гоулману представляет собой тест из 10 вопросов на выбор эмоциональной реакции или поведения в конкретно описанной ситуации. Тест Гоулмана проходить, в сравнении с тестом MSCEIT намного быстрее, но, учитывая, что теория Голумана, согласно мнению многих ученых, имеет слабое научное обоснование и основана на личном опыте автора, наблюдениям и изучению литературы, валидность и правдивость результатов данного теста можно поставить под вопрос. Хотя данный тест является очень популярным среди различных входных тестирований при прохождении собеседований. Перейдем к еще одной популярной модели эмоционального интеллекта, к модели Рувена Бар-Она. Рувен Бар-Он определяет эмоциональный интеллект как совокупность не когнитивных способностей, знаний, которые могут помочь человеку успешно преодолевать различные жизненные ситуации [2]. Он выделил 5 сфер, которые можно соотнести с пятью компонентами эмоционального интеллекта. Каж- 
дая из них в свою очередь содержит несколько дополнительных компонентов. Модель Р. Бар-Она представлена на рисунке 2.

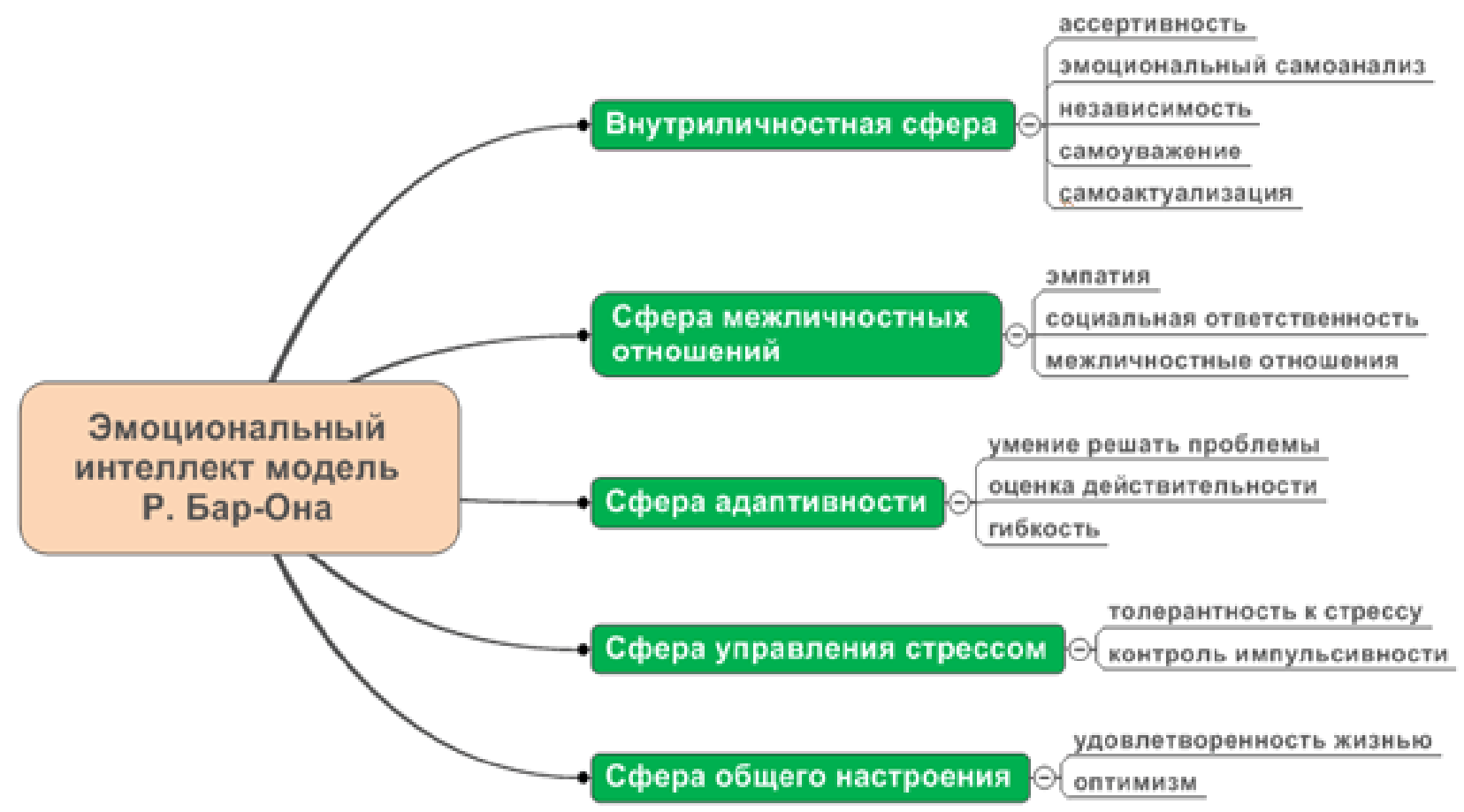

Рисунок 2. Модель эмоционального интеллекта Рувена Бар-Она

Модель Р. Бар-Она охватывает достаточно широкий спектр способностей человека. Поясним некоторые из них. Под ассертивностью автор понимает способность не только ясно выражать собственные мысли и эмоции, но и уметь добиваться желаемого, но с учетом потребностей других людей и законными способами. Самоактуализация - это непрерывный процесс самосовершенствования и реализации собственного потенциала. Самоактуализация связана с чувством удовлетворения жизнью и собой. Под удовлетворенностью жизнью из сферы общего настроения Рувен Бар-Он понимает умение человека радоваться, находить умиротворение и воодушевление. Противоположный эффект на эту сферу оказывают депрессивные состояния, печаль, излишня тревожность и раздражительность. Стоит также отметить, что оптимизм в данной модели совсем не означает склонность идеализировать жизнь и верить только в хо- 
рошее. Скорее, оптимизм должен выступать как звено рациональности и способствовать развитию навыка видеть положительные стороны в некоторых ситуациях и не унывать по пустякам. Бар-Он разработал опросник, в который включил 15 шкал. Несмотря на популярность данного метода и обязательное включение данного метода почти во все научные работы, эмпирическое обоснование выбора именно этих компонентов эмоционального интеллекта отсутствует [2]. Опросник составлен достаточно субъективно, на основании личного опыта автора. Стоит отметить, что именно Р. Бар-Он ввел аббревиатуру EQ, которая широко используется.

Рассмотрим последнюю модель эмоционального интеллекта отечественного ученого Дмитрия Владимировича Люсина. Под эмоциональным интеллектом Д.В. Люсин определяет способность человека к понимаю своих и чужих эмоций и к управлению ими. Согласно теории Д.В. Люсина, человек обладает возможностями распознать эмоцию (установить факт ее наличия у себя или других), может такую эмоцию идентифицировать (описать словами), он прекрасно осведомлен о причинах возникновения именно такой эмоции и ее последствиях. Эти качества ведут к пониманию эмоций. За управление эмоциями отвечают качества: возможность регулировать силу эмоций, контролировать выражение эмоций и вызывать у себя ту или иную эмоцию, если это необходимо. Дмитрий Владимирович не относит эмоциональный интеллект к чисто когнитивным способностям. Он считает, что способности к управлению и детальному понимаю эмоций и уровень интереса к внутреннему миру людей тесно взаимосвязаны. Д.В. Люсин предлагает рассматривать эмоциональный интеллект с точки зрения двойственной природы. С одной стороны, он связан с личными качествами, а с дугой - с когнитивными способностями. Д.В. Люсин развивает идеи Г. Гарднера о существовании внутриличностного и межличностного эмоционального интеллекта. Модель эмоционального интеллекта по Д.В. Люсину представлена наглядно в таблице 5 [сост. автором по 52]. 
Таблица 5.

Модель эмоционального интеллекта Д. В. Люсина

\begin{tabular}{|l|l|}
\hline \multicolumn{1}{|c|}{ Межличностный ЭИ } & \multicolumn{1}{c|}{ Внутриличностный ЭИ } \\
\hline - Шкала МП & - Шкала ВП \\
$\begin{array}{l}\text { Понимание чужих эмоций } \\
\text { вербальные и невербаль- } \\
\text { ные признаки) }\end{array}$ & $\begin{array}{l}\text { Понимание своих эмоций (распо- } \\
\text { знавание и вербальное описание) }\end{array}$ \\
\hline $\begin{array}{l}\text { - Шкала МУ } \\
\text { Управление чужими эмо- } \\
\text { циями. Склонности к мани- } \\
\text { пуляции }\end{array}$ & $\begin{array}{l}\text { Управление своими эмоциями } \\
\text { (осознавать, вызывать и поддержи- } \\
\text { вать нужные эмоции) }\end{array}$ \\
\cline { 2 - 2 } & $\begin{array}{l}\text { Шкала ВЭ } \\
\text { Контроль экспрессии (склонность к } \\
\text { регуляции внешних проявлений) }\end{array}$ \\
\hline
\end{tabular}

Д.В. Люсин представил пять шкал, которые описывают различные личностные характеристики. Кроме уровня межличностного и внутриличностного эмоционального интеллекта, автор выделяет еще две шкалы: ПЭ и УЭ - понимание эмоций и управление ими. Для оценки уровня эмоционального интеллекта Д.В. Люсин разработал опросник ЭмИн, в который входят 46 утверждений. Участник опроса должен выразить свое согласие или несогласие по каждому из утверждений. Результаты группируются сначала в 5 основных шкал, а затем, при объединении, можно дать оценку обобщенным шкалам. Данный опросник обладает высокой надежностью. Первые тесты были проведены в 2004 году, а в 2009 тест прошел апробацию на выборке в 745 человек. Результаты исследования были представлены в научных статьях [51]. 
Рассмотрев все наиболее популярные модели для определения уровня эмоционального интеллекта, для проведения исследования будет применена методика Д.В. Люсина. Все рассмотренные модели включали описание отдельных индикаторов, а опросник Д.В. Люсина описывает сам эмоциональный интеллект. Такая концепция удобна для контроля внутренней валидности исследования. ЭмИн тест на определение уровня эмоционального интеллекта имеет четкие предписания по его расшифровке, результаты такого опроса можно применять в дальнейшем исследовании.

Исходя из вышеизложенного, можно сделать вывод о том, что феномен эмоционального интеллекта действительно влияет на успешность человека, на принятие решений, на формирование экономического поведения. Особенно учитывая перераспределение трудовых ресурсов между секторами экономики. В сфере услуг и торговли заняты намного больше людей трудоспособного возраста, чем в реальном секторе экономики. С 2012 года в сфере сельского хозяйства количество работников уменьшилось на 19,6 \%, в промышленности на 2,5 \%, в строительстве - 1,2 \%. Прямо пропорционально возросло число занятых в сфере услуг и торговли, как В2В, так и В2С. Работа в этих сферах строится на ежедневном взаимодействии с людьми, отчасти успех сделок и прибыль компании зависит от мастерства тех, кто работает на передовой, - отдела сбыта. У руководителей отдела сбыта и директоров по коммерции есть разработанные показатели, по которым они отслеживают эффективность работы, но зачастую объяснить, почему один сотрудник продает дороже, другой быстрее, третий - лучше работает с «тяжелыми» клиентами, не поможет ни одна формула и ни один показатель. А в каждом конкретно взятом случае любая недоработка, недостаток и непрофессионализм коммуникации может вылиться в упущенные возможности. Что такое один упущенный клиент? Рост стоимости одного контракта при расчете маркетингового бюджета, рост затрат на содержание оптимального текущего запаса продукции, рост затрат на выплаты товар- 
ного кредита, если товар предоставляется на условиях факторинга, снижение рентабельности бизнеса. Особенно это актуально и в эпоху развития поведенческой экономики, когда рациональность выбора потребителей была поставлена под вопрос и изучением их поведения сейчас занимаются экономисты. Раз поведение человека обусловлено эмоциями, а эмоции могут быть скорректированы уровнем эмоционального интеллекта, его роль растет во всех сферах жизнедеятельности общества.

\section{3. Роль эмоционального интеллекта в деятельности предприятия}

Перемены, которые происходят сегодня в экономической и бизнес-среде позволяют говорить о том, что не только некая совокупность количественных данных и коэффициентов определяют успешность деятельности предприятия. Очень много зависит от руководителей, которые предопределяют успех компании решениями, которые они принимают ежедневно. А любой процесс принятия управленческих решений затрагивает определенный спектр эмоций и психических реакций, особенно в ситуациях риска, давления, многозадачности, неопределенности и многих других факторов. Следовательно, эффективность управления компанией напрямую зависит от умения контролировать, понимать и осознавать не только свои эмоции, но и эмоции своих подчиненных и любых других людей, с которыми приходится взаимодействовать для решения поставленных задач.

Речь пойдет не столько об оценке результатов деятельности и связи таких результатов с эмоциональным интеллектом, сколько об эффективности деятельности. Оценка результата деятельности предприятия или подразделения не дает главного ответа на вопрос, а бы- 
ли ли максимально использованы имеющиеся ресурсы. Понятие эффективности как раз включает в себя и степень реализации поставленных задач. Одним из основных инструментов для анализа деятельности руководителей или предприятия является система ключевых показателей эффективности, или KPI [53]. Еще в литературе существует определение - система сбалансированных показателей (ССП), которая была разработана исследователями из Гарварда Р. Капланом и Д. Нортоном. Речь пойдет именно о КРI, потому что логико-дедуктивные модели, которые использовались ранее, например Du Pont, были ограничены в использовании ввиду узости содержащихся в них методик оценки результатов деятельности предприятия. В частности, такие методики не включали в арсенал нефинансовые показатели, которые могли бы повлиять на качество всестороннего анализа факторов, которые влияют на эффективность работы предприятия. Методика, которую разработали Нортон и Каплан, включает оценку четырех аспектов деятельности компании: внешние и внутренние факторы, финансы и персонал. При этом она не имеет никаких ограничений: в ее структуру возможно добавить дополнительные индикаторы вне зависимости от их количества и состава. Еще одно отличие ССП от других логико-дедуктивных моделей заключается в тесной взаимосвязи финансовых и нефинансовых показателей, которые позволяют сформировать причинноследственные связи [54]. При анализе показателей, входящих в структуру ССП, можно сделать вывод о качестве принятых решений, которые находят отражение в показателях эффективности деятельности предприятия. Все решения, которые принимает руководитель, влияют на результаты экономической деятельности предприятия. Задачи, которые стоят перед руководителями подразделения, включают в себя не только приложение полученного опыта и знаний, но и сбор сведений, который может быть связан с преодолением «коммуникативных барьеров», в процессе чего детерминантом результативности выступает и степень адекватного восприятия полу- 
чаемой информации от заинтересованного лица, с учетом переработки вводных данных на предмет наличия «скрытых мотивов», возможного факта манипуляции и другого деструктивного влияния.

Как было уже указано выше, эмоции играют большую роль в процессе принятия решений. И в последние годы исследование влияния уровня эмоционального интеллекта на результаты профессиональной деятельности человека и на результаты эффективности работы предприятия в целом достаточно распространены и востребованы. Хотелось бы подробно описать исследования Е.А. Хлевной в области изучения взаимосвязи уровня эмоционального интеллекта руководителей и экономической эффективности организации. Исследование проводилось на нескольких предприятиях Москвы и Московской области. В выборку вошли предприятия, которые использовали ССП для оценки эффективности работы, всего было исследовано 166 предприятий и руководителей. Подтверждение гипотезы о влиянии уровня эмоционального интеллекта на эффективность деятельности руководителей проводилось посредством применения методов регрессионного анализа. Е.А. Хлевной были получены следующие результаты: во-первых, шкалы эмоционального интеллекта находятся в положительной взаимосвязи со многими элементами ССП, во-вторых, высокая связь наблюдается между КРІ и шкалой понимания и анализа эмоций, в-третьих, все показатели финансовых составляющих ССП положительно коррелируют со шкалой использования эмоций. Уровень корреляции превышает 0,5 \% [55]. Показатели рентабельности активов и прибыли до уплаты налогов хотя и довольно слабо, но тем не менее тоже коррелируют со шкалой идентификации эмоций. Абсолютно все показатели, которые характеризуют блок удовлетворенности клиентов, положительно коррелируют со шкалой сознательного управления эмоциями. Приведем результаты исследования Е.А. Хлевной в таблице 6. 
Таблица 6.

Результаты регрессионного анализа влияния уровня эмоционального интеллекта на эффективность деятельности руководителей

\begin{tabular}{|c|c|c|c|}
\hline $\begin{array}{c}\text { Зависимая } \\
\text { переменная } \\
\text { в модели }\end{array}$ & $\begin{array}{c}\text { F- } \\
\text { критерий }\end{array}$ & R2 & $\begin{array}{c}\text { Переменные в модели: стандартизиро- } \\
\text { ванные коэффициенты } \beta\end{array}$ \\
\hline $\begin{array}{c}\text { Средний } \\
\text { уровень } \\
\text { выполне- } \\
\text { ния КРІ }\end{array}$ & $23,72 * * *$ & 0,371 & $\begin{array}{l}\text { Шкала: идентификация эмоций } \\
\left(\beta=0,275^{* * *}\right) \\
\text { Шкала: использование эмоций } \\
\text { в решении проблем }(\beta=0,337 * * *) \\
\text { Шкала понимание и анализ эмоций } \\
(\beta=0,392 * * *) \\
\text { Шкала: сознательное управление } \\
\text { эмоциями }(\beta=0,237 * * *)\end{array}$ \\
\hline $\begin{array}{c}\text { Финансо- } \\
\text { вая состав- } \\
\text { ляющая } \\
\text { КРI }\end{array}$ & $22,50 * * *$ & 0,359 & $\begin{array}{l}\text { Шкала: идентификация эмоций } \\
(\beta=0,054 * * *) \\
\text { Шкала: использование эмоций } \\
\text { в решении проблем }(\beta=0,597 * * *) \\
\text { Шкала понимание и анализ эмоций } \\
(\beta=0,237 * * *)(\beta=0,237 * * *) \\
\left(\beta=0,045^{* * *}\right) \\
\text { Шкала: сознательное управление } \\
\text { эмоциями }(\beta=0,047 * * *)\end{array}$ \\
\hline $\begin{array}{c}\text { Клиентская } \\
\text { состав- } \\
\text { ляющая } \\
\text { КРІ }\end{array}$ & $19,82 * * *$ & 0,330 & $\begin{array}{l}\text { Шкала: идентификация эмоций } \\
\left(\beta=0,026^{* * *}\right) \\
\text { Шкала: использование эмоций } \\
\text { в решении проблем }(\beta=0,037 * * *) \\
\text { Шкала понимание и анализ эмоций } \\
(\beta=0,049 * *) \\
\text { Шкала: сознательное управление } \\
\text { эмоциями }(\beta=0,557 * * *)\end{array}$ \\
\hline
\end{tabular}


Окончание Таблицы 6.

\begin{tabular}{|c|c|c|c|}
\hline $\begin{array}{c}\text { Зависимая } \\
\text { переменная } \\
\text { в модели }\end{array}$ & $\begin{array}{c}\text { F- кри- } \\
\text { терий }\end{array}$ & R2 & $\begin{array}{c}\text { Переменные в модели: стандартизиро- } \\
\text { ванные коэффициенты } \beta\end{array}$ \\
\hline $\begin{array}{c}\text { Состав- } \\
\text { ляющая } \\
\text { КРІ: внут- } \\
\text { ренние } \\
\text { бизнес- } \\
\text { процессы }\end{array}$ & $11,92 * * *$ & 0,229 & $\begin{array}{l}\text { Шкала: идентификация эмоций } \\
(\beta=0,183 * * *) \\
\text { Шкала: использование эмоций } \\
\text { в решении проблем }(\beta=0,160 * * *) \\
\text { Шкала понимание и анализ эмоций } \\
(\beta=0,427 * * *) \\
\text { Шкала: сознательное управление } \\
\text { эмоциями }(\beta=0,054 * *)\end{array}$ \\
\hline $\begin{array}{c}\text { Состав- } \\
\text { ляющая } \\
\text { КРІ: обу- } \\
\text { чение и } \\
\text { развитие } \\
\text { персонала }\end{array}$ & $18,79 * * *$ & 0,318 & $\begin{array}{l}\text { Шкала: идентификация эмоций } \\
(\beta=0,439 * * *) \\
\text { Шкала: использование эмоций в ре- } \\
\text { шении проблем }(\beta=0,203 * * *) \\
\text { Шкала понимание и анализ эмоций } \\
(\beta=0,280 * * *) \\
\text { Шкала: сознательное управление эмо- } \\
\text { циями }(\beta=0,039 * * *)\end{array}$ \\
\hline & & & \\
\hline
\end{tabular}

Также в ходе исследования удалось установить и тот факт, что средний уровень выполнения КРІ возможно спрогнозировать; так, эффективность деятельности руководителей в 22-38 \% случаев, в зависимости от исследуемой переменной, объясняется уровнем эмоционального интеллекта. Такой процент, согласно ее мнению, может быть характеризован как достаточно высокий, поскольку в модели 
не учитывались другие факторы, которые тоже немаловажны для оценки влияния на эффективность деятельности руководителей, например опыт работы, образование и так далее. Следовательно, результаты исследования свидетельствуют о том, что уровень эмоционального интеллекта руководителей влияет на выполнение ключевых показателей эффективности, которые в свою очередь отражают и результат работы предприятия: уровень прибыли, рентабельность инвестиций и так далее.

Тема взаимосвязи эмоционального интеллекта сотрудников в России пока малоизучена. Тем не менее на западе ей интересуются достаточно живо. В частности, наиболее интенсивно она рассматривается на предприятиях, которые занимаются продажей товаров и услуг. Отдел сбыта один из основных подразделений на таких предприятиях, потому что именно этот отдел вносит самый большой вклад в формирование прибыли предприятия, соответственно и рентабельности. Во многих предприятиях специалист по продажам инициирует, развивает и выстраивает работу с покупателем с момента первого контакта и до заключения сделки [56]. Каждый год компании по всему миру тратят миллиарды долларов на различные программы обучения команды специалистов по продажам [57]. Тем не менее руководители предприятий могут ясно не замечать некий пробел, который постоянно существует между средним уровнем показателей специалиста по продажам и высоким уровнем, хотя продуктивность присутствует и в том, и в другом случае [58]. Именно такой разрыв в производительности труда специалистов по продажам, зачастую можно компенсировать и, как следствие, увеличить прибыль предприятия. Речь идет о том, что именно уровень эмоционального интеллекта и определяет производительность труда специалиста по продажам. Почему при прочих равных условиях один специалист заключает определенное количество контрактов, а второй, в аналогичных условиях не выполняет и половины от этого числа? Можно все списать на некие случайные факторы, которые 
дестабилизировали ситуацию и привели к нерезультативности, а что если мера такого фактора ничтожно мала и основная причина нерезультативности скрыта в другом, вполне измеримом факторе - то есть эмоциональном интеллекте?

Эмоциональный интеллект развивает у людей способность к творчеству, к принятию решений и, как следствие, помогает улучшить производительность труда [60]. С другой стороны, уровень эмоционального интеллекта благоприятно влияет на микроклимат внутри организации и позволяет людям выстраивать наиболее эффективную коммуникацию друг с другом и решать вопросы намного быстрее [61]. Крайне важно проводить исследования взаимосвязи эмоционального интеллекта с производительностью труда, чтобы лучше понять условия, при котором человеческие ресурсы используются максимально эффективно. Итак, поскольку взаимосвязь эмоционального интеллекта и эффективность деятельности руководителей предприятий была доказана эмпирическим путем, можно предположить, что есть также и взаимосвязь между уровнем эмоционального интеллекта и производительностью труда линейного персонала. В 2019 году на Всемирном Экономическом Форуме эмоциональный интеллект звучал как одна из основных компетенций, которой должен обладать успешный лидер, проактивный сотрудник и эффективный руководитель [59].

Так, линейный персонал, обладая высоким уровнем эмоционального интеллекта, способен эффективно решать любые задачи коммуникации в рамках общения с коллегами: от скорости и правильности постановки задач зависят качество и сроки их выполнения, что позитивно влияет на результат работы предприятия. В сфере торговли и услуг специалист по продажам - это лицо предприятия, один человек в состоянии сформировать общее представление клиента о предприятии и качестве предоставляемых услуг. Умение распознавать эмоции потенциального клиента, управлять ими и вы- 
зывать нужные эмоции способны привести предприятие не только к заключению выгодной сделки, но и повышению удовлетворенности обслуживания клиентам и, как следствие, к дополнительным рекомендациям предприятия как надежного партнера для ведения бизнеса. Совокупность этих факторов в итоге оказывает влияние на объем продаж, на прибыль и рентабельность инвестиций.

Специалисты, которые обладают высоким уровнем эмоционального интеллекта, способны намного более эффективно и быстро решать вопросы оперативного характера, которые зачастую в работе предприятия зависят не от умения быстро посчитать какую-либо формулу или коэффициент, а от умения установить контакт по телефону и пролоббировать интересы компании, что касается, например, ускорения сроков поставки товара, сроков оплаты товара и так далее. За счет этих факторов складывается способность компании адаптироваться к быстро меняющимся условиям, что является основой конкурентного преимущества на рынке. В литературе существует разделение персонала на предприятии на 3 вида: руководители, специалисты и технические исполнители. Каждый этот вид имеет свои особенности с точки зрения содержания труда, предмета труда и характера нагрузок, в том числе эмоциональных и умственных. Распределение труда всех сотрудников можно проследить по организационной структуре предприятия, но в данном случае речь пойдет о распределении обязанностей внутри одного отдела. Под разделением функциональных обязанностей в литературе понимается ограничения одного вида работ, которые требуют определенного комплекса навыков, подготовки, знаний и умений. Так, при разделении сотрудников на ведущих или старших в компании руководители предполагают, что именно эти сотрудники проявляют большой уровень профессионализма и они обладают отличными от других качествами, которые обуславливают высокие результаты деятельности предприятия. Как было указано выше, уровень эмоционального интеллекта во многом является тем фактором, который обуславливает 
успешность человеческой деятельности не только на личном, но и на профессиональном поприще. Следовательно, те обязанности, которые входят в должностную инструкцию для каждого работника, должны быть скорректированы в соответствии с уровнем эмоционального интеллекта, как детерминанты высокой эффективности деятельности не только отдельно взятой штатной единицы, но и предприятия в целом. Не у всех сотрудников на предприятии уровень эмоционального интеллекта высокий. Чаще всего эта способность индивидуальна, и в отделе сбыта на предприятии могут работать сотрудники с разным уровнем эмоционального интеллекта. Резонным является в данном случае вопрос разграничения функциональных обязанностей сотрудников с учетом уровня эмоционального интеллекта. Так, можно предположить, что сотрудник с низким уровнем эмоционального интеллекта способен добиваться больших результатов в случае постановки ему задач некоммуникативного свойства, а сотрудник, у которого значение уровня эмоционального интеллекта выше, способен демонстрировать выдающиеся результаты при выполнении задач коммуникативного свойства. 


\section{2. АНАЛИЗ ВЛИЯНИЯ ЭМОЦИОНАЛЬНОГО ИНТЕЛЛЕКТА НА ЭКОНОМИЧЕСКИЕ РЕЗУЛЬТАТЫ ДЕЯТЕЛЬНОСТИ ПРЕДПРИЯТИЯ}

Проанализировав понятие эмоционального интеллекта и его роль в деятельности предприятия, невозможно не согласиться с тем, что обходить такой показатель стороной при ведении торговой деятельности или предоставляя платные услуги населению просто невозможно. Учитывая долю этих секторов экономики в ВВП России. Более того, в последнее время увеличение занятых в перечисленных сферах растет неуклонно, а процент занятых в реальных секторах экономики, наоборот, уменьшается. Вопрос изучения эмоционального интеллекта также может быть важен и в относительно новой сфере предпринимательства - социального предпринимательства, главная задача которого - это «предпринимательская деятельность, направленная на достижение общественно полезных целей, способствующая решению социальных проблем граждан и общества» [62]. Поправка к закону «О развитии малого и среднего предпринимательства в Российской Федерации» была принята и одобрена Советом Федерации 23 июля 2019 года. В этой сфере вопросы коммуникации с людьми будут выходить на первое место [63].

Проанализируем влияние эмоционального интеллекта на результаты деятельности предприятия. Исследование проводилось на предприятиях, которые ведут деятельность в сфере продаж и ремонта автомобильных средств и прицепов к ним. В большинстве случаев такие предприятия относятся к малым предприятиям или микропредприятиям, в зависимости от региона. Как правило, любой дилерский центр в городе с населением более 1 млн, осуществляющий услуги по ремонту и продаже автомобилей и аксессуаров, имеет среднесписочную численность около 75 человек. Но есть и дилерские центры, которые работают в структуре холдинга. Они уже от- 
носятся к средним предприятиям со среднесписочной численностью от 100 человек до 200. Эти значения легко спрогнозировать и для предприятий других городов, поскольку импортер или представитель производителя на территории России предписывает определенный ряд правил не только к квалификации нанимаемого персонала, но и обращает внимание на количество необходимых сотрудников в соответствии с объемом продаж и ремонта транспортных средств. Дилерские предприятия вынуждены порой выстраивать работу в рамках строгих ограничений со стороны регламентов импортера, где они не имею зачастую права отказываться от определенных статей расхода или, наоборот, обязаны их увеличить.

Учитывая статистику развития автомобильного бизнеса с 2014 года, дилер вынужден использовать любую возможность увеличения эффективности и снижения структуры затрат, не нарушая строгого регламента взаимодействия с поставщиком. Только в 2019 падение рынка составило в мае 6,7 \% по сравнению с аналогичным периодом 2018 года, по официальным данным АЕВ [64]. Это падение самое значительное за последние два года. В секторе «Торговля оптовая и розничная; ремонт автотранспортных средств и мотоциклов» заняты 16 \% трудоспособного населения [63]. Кризис этой сферы приведет к снижению уровня оплаты труда занятых в ней вследствие отсутствия спроса, уход сотрудников из отрасли, что приведет к ухудшению ситуации и появлению у предприятий нежелательных и непредвиденных издержек в виду отсутствия квалифицированного состава специалистов. Следовало бы также отметить, что на официальную статистику от Ассоциации Европейского Бизнеса стоит делать существенную поправку. Игроки рынка вразрез с данными АЕВ отмечают, что автомобильный рынок не просто падает, а находится в депрессии, именно такие предпосылки и были перед кризисом 2008 года. Дело в наличии «желтых автомобилей» на складах - деюре выкупленные и проданные для статистики АЕВ, де-факто - до сих пор находящиеся на складах предприятий, вопрос возврата вло- 
женных денежных средств в которые остается открытым [66]. Дилеры вынуждены регулярно замораживать денежные средства, чтобы выполнить планы, которые ставит производитель, и, как следствие, получить бонусы. Объем ежемесячной доли таких автомобилей зависит от бренда и реальные цифры падения в отрасли доподлинно неизвестны. Известно только, что в сентябре АЕВ зафиксировали падение на 0,5 \% по сравнению с аналогичным периодом прошлого года, в то время как количество регистрационных действий в ГИБДД по новым автомобилям сократилось на 11,2 \% [66]. В связи с этим вопрос освоения новых подходов и техник к управлению прибылью предприятия и 20 \% сотрудников, которые приносят 80 \% результата, актуален как никогда. Каждый входящий в шоу-рум клиент в обстановке депрессивных настроений рынка - это уже затраты на SMM-маркетинг, интернет-маркетинг, медиа размещение и многое другое. Сотрудник сбытового отдела своим профессионализмом, умением считывать и интерпретировать весь комплекс вербальных и невербальных признаков, согласно гипотезе, при наличии у человека потребности в приобретении товара, может увеличить шансы предприятия заключить сделку, оправдав вложения в узнаваемость бренда, и получить прибыль.

\section{1. Исследование влияния эмоционального интеллекта сотрудников на результаты деятельности}

Описание методики проведения исследования. Оценим влияние эмоционального интеллекта на экономические результаты деятельности предприятия. Для этого изучались показатели сотрудников отделов сбытов предприятий, которые занимаются торговлей легковыми автомобилями. Сотрудник отдела сбыта проходил опрос на определение уровня эмоционального интеллекта по методике Д. В. Люсина. Также по каждому такому сотруднику предоставля- 
лись данные о его эффективности работы. Опрос и небольшое анкетирование проводилось с помощью Google Docs. Опросник и ряд контрольных вопросов по показателям эффективности работы сотрудника представлены в Приложении 1. После обработки предоставленных результатов опроса и анкет эмпирическое исследование проводилось статистическими методами: корреляционный анализ и регрессионный посредством STATISTICA 10, MS Excel.

По каждому специалисту по продажам, кроме уровня его эмоционального интеллекта, запрашивались следующие данные (таблица 7):

Таблица 7.

Показатели эффективности работы сотрудника отдела сбыта

\begin{tabular}{|l|c|}
\hline \multicolumn{1}{|c|}{ Показатель } & Методика расчета \\
\hline Конверсия по звонкам & $\mathrm{K}_{3}=\frac{\text { Визиты по звонкам }}{\text { Всего входящих звонков }}$ \\
\hline Конверсия по визитам & $\mathrm{K}_{\mathrm{B}}=\frac{\text { Фактические продажи }}{\text { Всего входящих визитов }}$ \\
\hline $\begin{array}{l}\text { Коэффициент выполнения индиви- } \\
\text { дуального плана по продажам }\end{array}$ & $\mathrm{K}_{\text {пл }}=\frac{\text { Фактические продажи }}{\text { Планируемые продажи }}$ \\
\hline
\end{tabular}

Конверсия - широко используемый термин и в продажах, и в маркетинге. В продажах он означает соотношение между клиентами, которые достигли определенного этапа в ходе сделки, к общему числу потенциальных покупателей, которые проявили интерес к продукту [73]. Конверсия по звонкам показывает умение сотрудника работать с потенциальными клиентами по телефону. В классической воронке продаж в автомобильном бизнесе конверсия по первичным звонкам измерялась отношением числа визитов к общему числу первичных звонков. Первичный звонок - это первый звонок нового клиента в салон, то есть до момента этого звонка клиент ни 
разу не звонил в дилерский центр и не приходил в шоу-рум. Цель сотрудника отдела продаж при отработке первичного звонка - договориться на встречу с потенциальным клиентом уже в салоне. В зависимости от того, сколько клиентов после первичного звонка приходят на встречу в шоу-рум, оценивается профессионализм менеджера, его умение при первом же звонке заинтересовать клиента и добиваться поставленных целей. В данной работе этот показатель был немного видоизменен. Для проведения исследования запрашивалось значение данного показателя минимум за 6 месяцев. По полученному временному ряду был проведен одномерный анализ данных и рассчитан коэффициент вариации для оценки качества среднего значения. В случае если коэффициент вариации удовлетворял пороговому значению в 33 \%, среднее значение включалось в исследование.

Конверсия по визитам в классической воронке продаж в автомобильном бизнесе показывает, сколько клиентов, которые первый раз пришли в шоу-рум дилера, оставили свои контактные данные специалисту по продажам. Данный показатель демонстрирует профессиональный уровень специалиста в работе с новыми клиентами: умение при первой встрече расположить к себе, выявить потребности и настроить клиента на дальнейший диалог о приобретении товара. В работе классический вид будет видоизменен. Конверсия по первичным визитам будет определяться отношением фактических проданных автомобилей к общему числу клиентов, которые впервые пришли в шоу-рум в рамках исследуемого периода. Это может быть месяц, квартал, год. Для проведения исследования запрашивалось значение данного показателя минимум за 6 месяцев. По полученному временному ряду был проведен одномерный анализ данных и рассчитан коэффициент вариации для оценки качества среднего значения. Если коэффициент вариации удовлетворял пороговому значению в $33 \%$, среднее значение включалось в исследование. 
Коэффициент выполнения индивидуального плана по продажам - отношение фактических продаж к планируемым продажам. Это ключевой показатель производительности труда специалиста отдела сбыта. Для проведения исследования запрашивалось значение данного показателя минимум за 6 месяцев. По полученному временному ряду был проведен одномерный анализ данных и рассчитан коэффициент вариации для оценки качества среднего значения. В случае если коэффициент вариации удовлетворял пороговому значению в $33 \%$, среднее значение включалось в исследование.

Данные показатели не являются универсальными, в зависимости от отрасли, предприятия (даже в рамках автомобильного рынка) они могут рассчитываться индивидуально с учетом внутренних регламентов и специфики работы компании. Как правило, они включены в систему сбалансированных показателей для анализа эффективности работы коммерческого отдела предприятия и могут быть рассчитаны как по отделу в целом, так и по каждому сотруднику для оценки уровня его профессионализма и компетенций.

Описание выборки. Исследование проводилось в 2019 году на дилерских предприятиях, которые специализируются на продаже легковых автомобилей. Всего было опрошено 189 человек. 100 \% составляли менеджеры отдела продаж легковых автомобилей. В этой структуре $54 \%$ работают на малых предприятиях, $46 \%$ - на средних предприятиях. Согласно Федеральному закону от 24.07.2007 № 209-ФЗ (ред. от 27.11.2017) «О развитии малого и среднего предпринимательства в Российской Федерации», субъектами малого предпринимательства являются хозяйствующие субъекты (юридические лица и индивидуальные предприниматели), отнесенные в соответствии с условиями, установленными вышеуказанным Федеральным законом, к малым предприятиям, микропредприятиям и средним предприятиям. 
К субъектам малого предпринимательства относят зарегистрированные в соответствии с законодательством Российской Федерации хозяйственные общества, хозяйственные партнерства, кооперативы, потребительские кооперативы, крестьянские хозяйства и индивидуальных предпринимателей [67]. Более подробно критерии, по которым предприятие можно определить к той или иной категории, описаны в статье 4 вышеуказанного Федерального Закона. Основными условиями являются: численность персонала от 16 до 100 человек, выручка предприятия, не превышающая порогового значения в 120 млн руб. без учета НДС [68].

Также выборку можно разделить и по представителям премиум- и масс-бренда: 63 \% представляли премиум бренд, а масс бренд $37 \%$. К премиум-бренду можно отнести автомобили, произведенные согласно определенным стандартам качества, реализация которых связана с соблюдением строгих директив производителя, рекомендованная розничная стоимость которых начинается от 1800 тыс. руб. Примерами могут быть Audi, Mercedes-Benz, BMW. Рекомендованная стоимость автомобиля масс сегмента или масс-бренда начинается от 750 тыс. руб. [72]. Основное отличие между этими двумя категориями - ценовая политика.

Средний возраст респондентов от 21 до 35 лет, из них $11 \%$ женщин и $89 \%$ мужчин. Средний стаж работы в автомобильном бизнесе и в группе женщин, и в группе мужчин составляет 7 лет по результатам опроса. Опыт работы в отрасли менее одного года в выборке почти не наблюдался. В таблице 8 представлена структура выборки. 
Таблица 8.

Структура выборки

\begin{tabular}{|l|c|c|}
\hline \multicolumn{1}{|c|}{ Показатель } & $\begin{array}{r}\text { Число опро- } \\
\text { шенных (чел.) }\end{array}$ & $\begin{array}{c}\text { Процент опро- } \\
\text { шенных (\%) }\end{array}$ \\
\hline Гендерная принадлежность & 168 & 89 \\
\hline Мужчины & 21 & 11 \\
\hline Женщины & 189 & 100 \\
\hline Итого & 119 & 63 \\
\hline Специфика бренда & 70 & 37 \\
\hline Премиум-бренд & 189 & 100 \\
\hline Масс-бренд & 102 & 54 \\
\hline Итого & 87 & 46 \\
\hline Численность персонала на предприятии & 100 \\
\hline от 0 до 100 & 189 & \\
\hline от 101 до 250 & \\
\hline Итого & \\
\hline
\end{tabular}

После описания метода исследования, показателей, которые используются для проведения исследования и выборки, перейдем к оценке влияния эмоционального интеллекта на экономические результаты деятельности сотрудников. Будут изучаться несколько видов взаимосвязей: влияние общего уровня эмоционального интеллекта и отдельно его компонентов на производительность труда специалиста по продажам, после чего будет установлена взаимосвязь между производительностью труда и результатами экономической деятельности предприятия. По всем исследуемым показателям была составлена корреляционная матрица в Приложении 2. В работе бу- 
дут рассмотрены подробно те взаимосвязи показателей, в которых рзначения удовлетворяют условиям и являются статистически значимыми и которые представляют особый интерес для исследования. Исследование проводилось индуктивным методом. Начнем с оценки влияния общего уровня эмоционального интеллекта, далее перейдем к оценке влияния его компонентов.

Анализ влияния уровня общего эмоционального интеллекта специалиста по продажам на коэффициент выполнения индивидуального плана. Была выдвинута следующая гипотеза: чем выше уровень общего эмоционального интеллекта сотрудника корпоративного отдела, тем выше коэффициент выполнения индивидуального плана по продажам. Минимальное значение уровня общего эмоционального интеллекта в выборке - 65 пунктов, максимальное - 125 пунктов. Минимальное значение коэффициента выполнения ежемесячного индивидуального плана по продажам - 60 \%, максимальное - $142 \%$. Представим взаимосвязь данных показателей на рисунке 3.

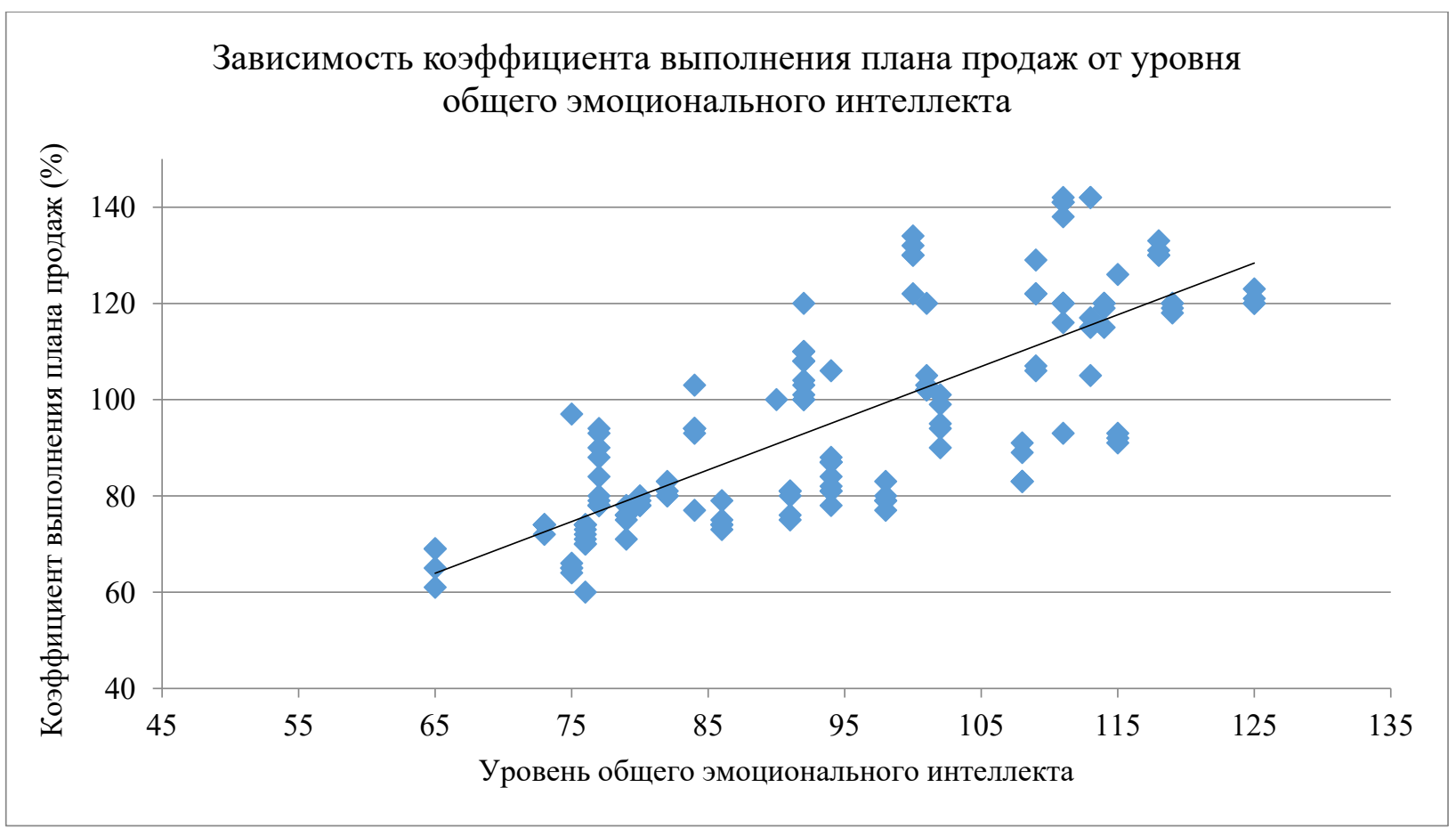

Рисунок 3. Зависимость коэффициента выполнения плана продаж от уровня общего эмоционального интеллекта 
На графике прослеживается взаимосвязь прямая связь показателей, все выбросы уже были элиминированы из выборки. Был проведен корреляционный анализ количественных признаков. В результате были получены следующие данные: корреляция Пирсона - 0,78, коэффициент статистически значим ( $\mathrm{t}_{\text {набл }}-6,14, \mathrm{t}_{-}$табл $-1,97$. Наблюдаемое значение превышает табличное с вероятностью ошибки $<5 \%$ ). Поскольку t- набл. больше, следовательно, можно сделать вывод о том, что взаимосвязь статистически значима, и подтвердить гипотезу о том, что с повышением уровня общего эмоционального интеллекта увеличивается и процент выполнения или даже перевыполнения ежемесячного индивидуального плана по продажам. Был проведен регрессионный анализ взаимосвязи этих показателей. В формуле 1 представлено полученное уравнение вида:

$$
Y=40,032+0,569 x+\varepsilon
$$

где Y - уровень эмоционального интеллекта;

$\mathrm{X}$ - коэффициент выполнения плана продаж (\%).

Оценка качества регрессионного уравнения показала следующие результаты: оба параметра уравнения статистически значимы. Значение коэффициента детерминации - 0,61, и он статистически значим. Таким образом, изменение в выполнении ежемесячного индивидуального плана продаж на 61 \% объясняется уровнем эмоционального интеллекта сотрудников. Расчеты показали, что средняя ошибка аппроксимации составляет 8,8 \%. Это не превышает порогового значения в 15 \%, поэтому качество уравнения можно считать приемлемым. Условие Гаусса - Маркова о равенстве нулю среднего значения остатков выполняется, условие о нормальности распределения остатков выполняется. Проверка на отсутствие гетероскедастичности показала, что в остатках наблюдается гомоскедастичность. Статистика Дарбина - Уотсона составляет 1,85. Эта величина попадает в зону отсутствия автокорреляции. Уравнение соответствует всем критериям качества, его можно 
использовать для описания характера взаимосвязи исследуемых переменных, а также для прогнозирования. Тем не менее существуют факторы, которые составляют оставшиеся 39 \% и которые могут повлиять на производительность труда специалиста по продажам. Выдвигаемая гипотеза подтвердилась полностью. Когда сотрудник отдела сбыта обладает более развитыми качествами, которые помогают управлять эмоциями и своими, и других людей, понимать эмоции и считывать их, тогда его производительность труда, как продавца, намного выше, он способен продавать намного больше, следовательно, предприятие выполняет план и прибыль такого предприятия растет.

Выполнение плана продаж - один из важных экономических результатов деятельности предприятия. При прочих равных условиях следствием увеличения объема продаж является пропорциональный рост прибыли предприятия. При выполнении ежемесячных планов продаж предприятие движется в рамках согласованного годового бюджета. Стабильное выполнение плана по продажам влияет на финансовую устойчивость предприятия.

Анализ влияния уровня общего эмоцчонального интеллекта на конверсию по звонкам. Показатель конверсии по звонкам оказывает влияние на экономические результаты деятельности предприятия. Объяснить это влияние можно двумя способами. В первом случае речь идет об уже известном факте увеличения прибыли предприятия прямо пропорционально увеличению объема продаж, но с учетом некоторых ограничений. Например, в две компании позвонили по 100 человек в каждую, в первом случае конверсия по звонкам составила $10 \%$, во втором случае - 20 \%. В первой компании из 100 звонков на презентацию пришли 10 потенциальных покупателей, а во второй компании - 20 потенциальных покупателей. Несложно предположить, что шансов реализовать товар у второй компании будет больше, чем у первой. Во втором случае значимость показателя кон- 
версии по первичным звонкам для экономических результатов деятельности предприятия заключается в снижении стоимости контакта, что положительно сказывается на результатах экономической деятельности предприятия. Стоимость контракта, в классической теории - показатель эффективности деятельности служб маркетинга [69]. Хотя во многих современных предприятиях в сфере автомобильного бизнеса показатели эффективности службы маркетинга анализируются вместе с эффективностью коммерческого отдела. Предположим, затраты двух компаний на интернет-рекламу составили 100000 рублей. В обе компании позвонили по 100 человек. В первом случае конверсия по звонкам составила $10 \%$, во втором случае - $20 \%$. В первую компанию из 100 звонков пришли 10 потенциальных покупателей, а во вторую компанию - 20. При прочих равных условиях в первой компании стоимость одного контакта составила 10000 руб., во второй компании 5000 . Влияние значения показателя конверсии по первичным звонкам на экономические результаты деятельности предприятия даже на базе этих простых двух логических примеров очевидно. А что обуславливает повышенное значение показателя конверсии по первичным звонкам на первом и втором предприятии? Почему один сотрудник в состоянии добиться встречи с 10 потенциальными покупателями, а второй - со всеми 20? Выдвигается гипотеза о наличии взаимосвязи между уровнем общего эмоционального интеллекта сотрудника отдела сбыта и показателем конверсии звонкам. Минимальное значение уровня общего эмоционального интеллекта в выборке - 65 пунктов, максимальное - 125 пунктов. Минимальное значение показателя конверсии по звонкам - $1 \%$, максимальное - 25 \%. Представим взаимосвязь показателей на рисунке 4. 


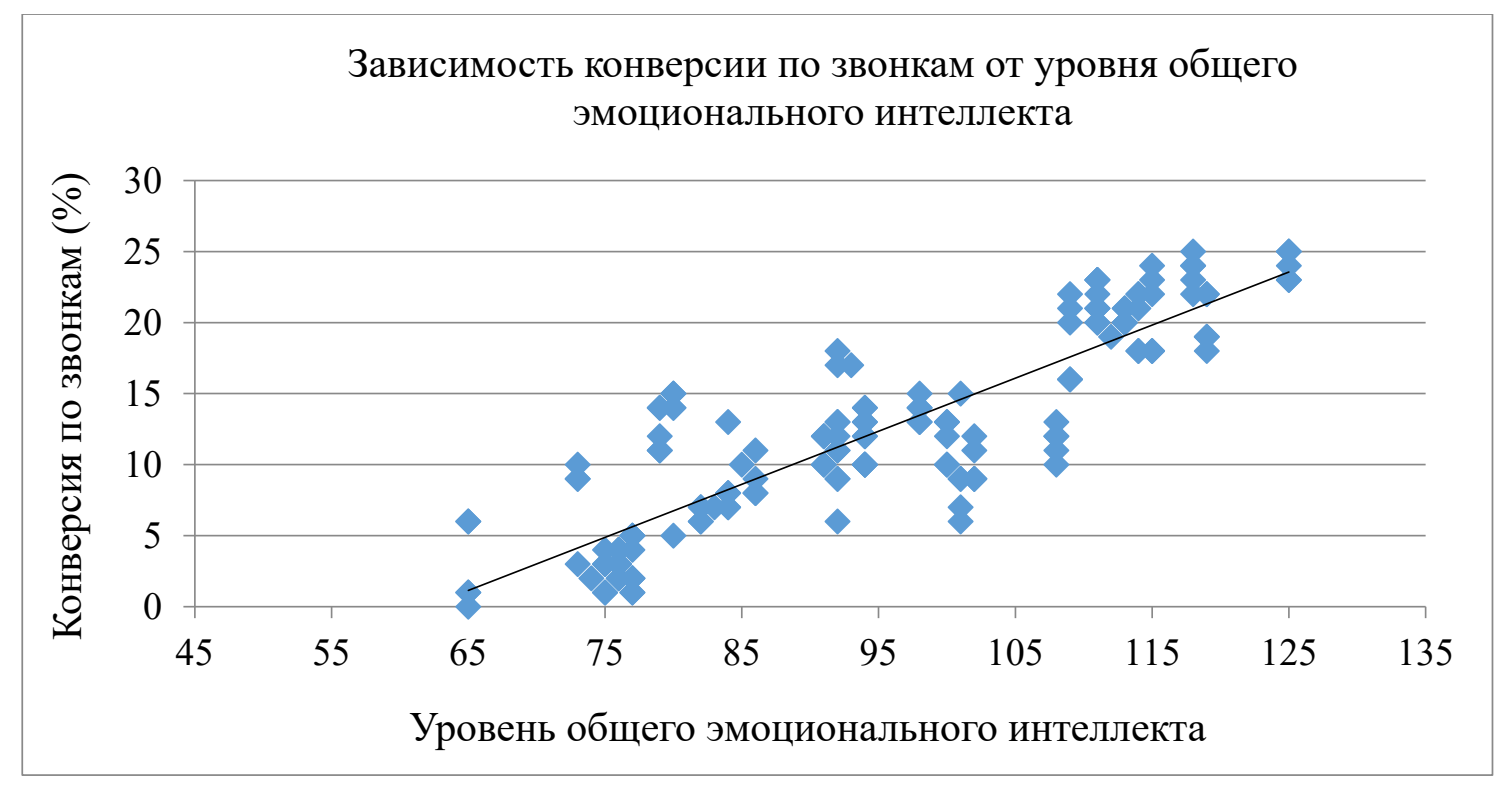

Рисунок 4. Зависимость конверсии по звонкам от уровня общего эмоционального интеллекта

На графике прослеживается взаимосвязь показателей, все выбросы удалены из выборки и на графике визуально не диагностируются. Если даже сравнивать с предыдущим графиком, то характер распределения более равномерный и более сильная связь прослеживается уже на этом этапе анализа. Сначала был проведен корреляционный анализ количественных признаков. В результате были получены следующие данные: корреляция Пирсона - 0,81, коэффициент статистически значим ( $\mathrm{t}_{\text {набл. }}-22,29, \mathrm{t}-$ табл. $-1,97$. Наблюдаемое значение превышает табличное с вероятностью ошибки $<5 \%$ ). По-

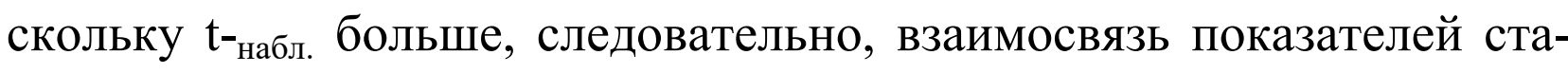
тистически значима. Гипотеза о том, что показатель конверсии по первичным звонкам зависит от уровня общего эмоционального интеллекта, утверждается. Коэффициент детерминации - 0,75, он был получен в ходе регрессионного анализа и является статистически значимым. Таким образом, изменение в значении показателя конверсии по звонкам $75 \%$ объясняется уровнем общего эмоционального интеллекта. Если в первом случае речь шла об умеренной связи, то здесь прослеживается сильная связь между показателями. 
При общении по телефону с потенциальными покупателями, специалист отдела сбыта, эмоциональный интеллект которого более развит, склонен к оценке настроения потенциального покупателя по тембру речи, темпу речи, громкости и так далее. Специалист по продажам может настроить потенциального клиента на доброжелательную волну и добиться, таким образом, своей цели, которую он себе поставил при ведении беседы по телефону. Оценим влияние этой взаимосвязи на затраты предприятия на примере реальной компании. В качестве примера был взят период с февраля по июнь 2018 года - именно в это время в структуре сбытового отдела в компании ООО «Концепт Кар» произошли изменения. Изменился состав специалистов по продажам. За каждый месяц был выведен средний уровень общего эмоционального интеллекта по отделу на основании опроса сотрудников. Под затратами на маркетинг в данном случае брался бюджет, который был выделен только на интернет-рекламу поскольку по данному виду рекламной активности можно проследить количество звонков, которое в итоге поступило в дилерский центр. Данные по уровню эмоционального интеллекта, показателям производительности отдела продаж и затраты на маркетинг представлены в таблице 9.

Таблица 9.

Показатели деятельности отдела сбыта с марта по июнь 2018

\begin{tabular}{|c|c|c|c|c|c|c|}
\hline $\begin{array}{c}\text { Пери- } \\
\text { од }\end{array}$ & $\begin{array}{c}\text { Уровень } \\
\text { общего } \\
\text { эмоцио- } \\
\text { нального } \\
\text { интел- } \\
\text { лекта }\end{array}$ & $\begin{array}{c}\text { Общее } \\
\text { количе- } \\
\text { ство } \\
\text { звонков } \\
\text { (шт.) }\end{array}$ & $\begin{array}{c}\text { Общее } \\
\text { количе- } \\
\text { ство ви- } \\
\text { зитов по } \\
\text { звонку } \\
\text { (шт.) }\end{array}$ & $\begin{array}{c}\text { Конвер- } \\
\text { сия отде- } \\
\text { ла по } \\
\text { звонкам } \\
(\%)\end{array}$ & $\begin{array}{c}\text { Затраты } \\
\text { на мар- } \\
\text { кетинг } \\
\text { (руб.) }\end{array}$ & $\begin{array}{c}\text { Стои- } \\
\text { мость } \\
\text { одного } \\
\text { контакта } \\
\text { (руб.) }\end{array}$ \\
\hline $\begin{array}{l}\text { Фев- } \\
\text { раль }\end{array}$ & 89 & 156 & 15 & 10 & 198537 & 13235 \\
\hline Март & 89 & 198 & 17 & 9 & 287645 & 16920 \\
\hline Апрель & 103 & 223 & 25 & 11 & 267549 & 10701 \\
\hline Май & 103 & 230 & 21 & 9 & 259157 & 12340 \\
\hline Июнь & 103 & 224 & 32 & 14 & 301542 & 9423 \\
\hline
\end{tabular}


В феврале 2018 средний показатель уровня общего эмоционального интеллекта отдела продаж был 89 пунктов. При этом в компанию поступило 156 звонков. Из них 15 человек пришли в шоу-рум на личную встречу со специалистом отдела продаж или $10 \%$ от общего числа позвонивших. В апреле 2018 года были произведены кадровые перестановки, и в должность вступили два новых специалиста. С учетом пары месяцев, которые требуются на адаптацию и изучение продукта, были взяты конечные результаты за июнь 2018 года. Апрель и май месяцы можно считать непоказательными ввиду сложной оценки вклада каждого прибывшего сотрудника в общий результат отдела продаж. Средний уровень общего эмоционального интеллекта с учетом изменений в составе отдела составил 103 пункта. При этом за июнь 2018 в отдел продаж поступило 224 звонка. Из них в шоу-рум пришли 32 человека, или $14 \%$ от общего числа позвонивших. При этом стоимость одного контакта для компании уменьшилась на 3812 руб. Конверсия отдела по звонкам выросла на $5 \%$. Когда потенциальный покупатель заходит в шоурум, уже вычисляется следующий показатель - конверсия по визитам или сколько из тех, кто пришел в дилерский центр, уехали на новом автомобиле.

Анализ влияния уровня общего эмоционального интеллекта на конверсию по визитам. Когда потенциальный клиент приходит на личную встречу со специалистом по продажам, то именно в это время все навыки и умения, которые имеют прямое отношение к уровню эмоционального интеллекта, способны в полной мере проявиться. Это и умение по невербальным признакам считывать степень расположенности клиента к разговору, это талант настроить покупателя на нужный лад и вывести его на открытый диалог, это и способность при демонстрации товара вызвать нужные эмоции у потенциального потребителя, чтобы мечты и желания клиента трансформировались в цель и действия. Исследовались два показателя: уровень общего эмоционального интеллекта и значение показателя кон- 
версии по визитам. Была выдвинута гипотеза о влиянии уровня общего эмоционального интеллекта на показатель конверсии по визитам. Минимальное значение уровня общего эмоционального интеллекта в выборке - 65 пунктов, максимальное - 125 пунктов. Минимальное значение показателя конверсии по визитам - $12 \%$, максимальное -45 \%. Представим взаимосвязь показателей на рисунке 5 .

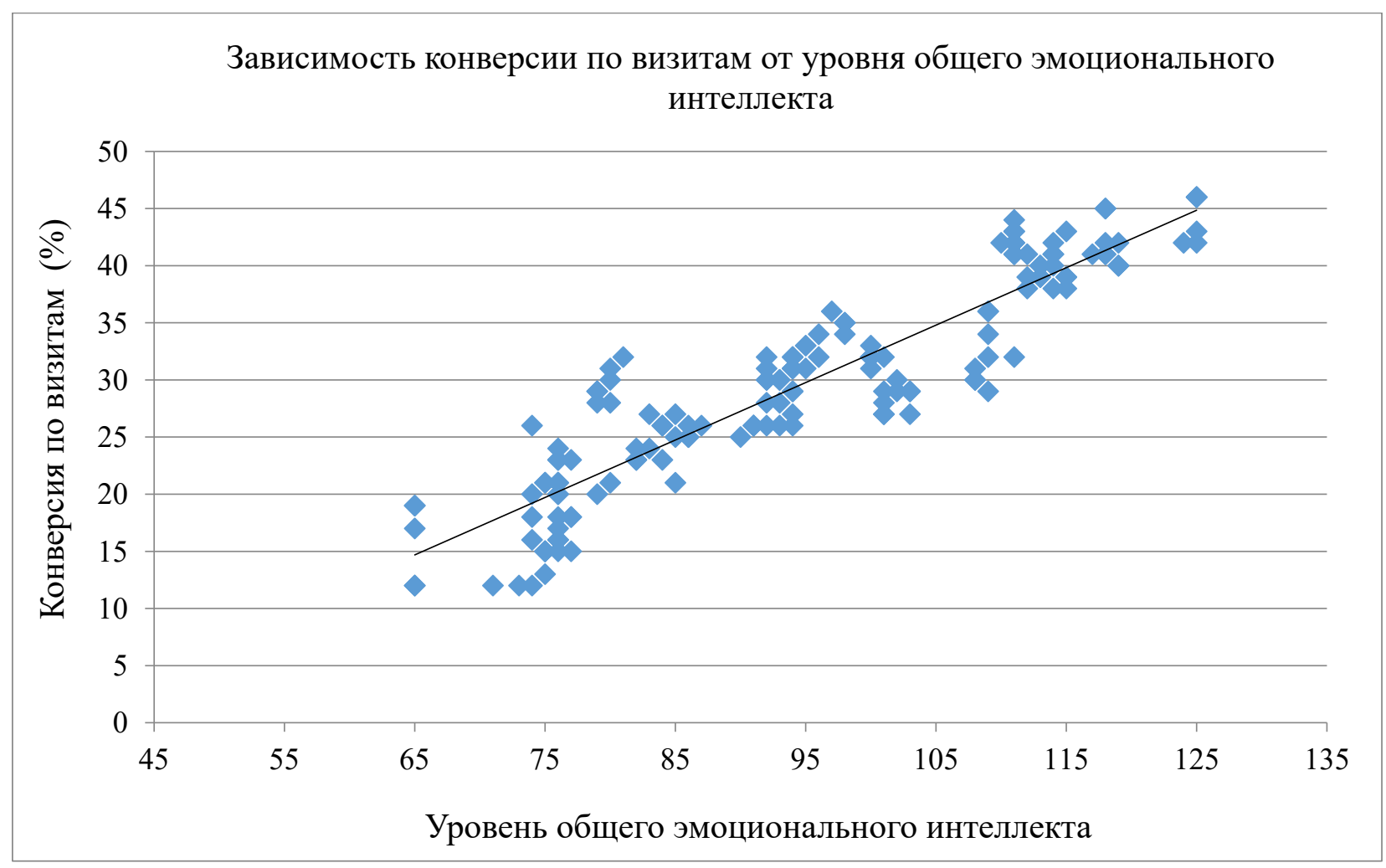

Рисунок 5. Зависимость конверсии по визитам от уровня общего эмоционального интеллекта

На графике визуально можно увидеть связь между этими двумя показателями. Сначала был проведен корреляционный анализ количественных признаков. В результате были получены следующие данные: корреляция Пирсона - 0,91, коэффициент статистически

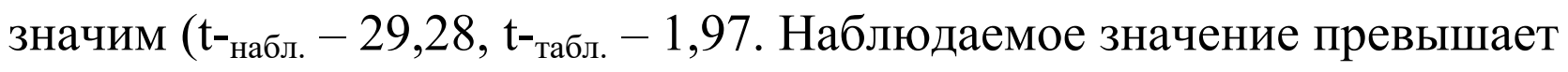

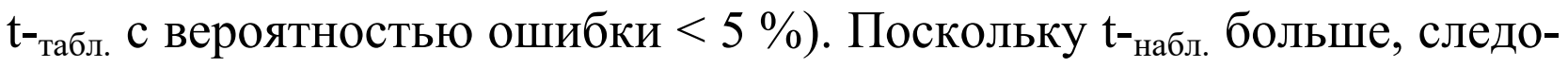
вательно, взаимосвязь показателей статистически значима. Гипотеза о том, что конверсия по визитам зависит от уровня общего эмоцио- 
нального интеллекта, утверждается. В ходе регрессионного анализа было получено следующее значение коэффициента детерминации 0,84 и он статистически значим. Таким образом, изменение в проценте конверсии по визитам на 84 \% объясняется уровнем общего эмоционального интеллекта. Результат, который был получен, в очередной раз подчеркивает важность уровня общего эмоционального интеллекта и указывает на то, что роль уровня эмоционального интеллекта специалиста по продажам является чуть ли не самым важным фактором, определяющим производительность труда продавца. И вполне можно предположить, что чем ближе потенциальный покупатель к продавцу, тем больше у продавца открывается возможностей для использования всего арсенала средств, чтобы склонить потенциального клиента к покупке, порой и с использованием техник манипуляции. Эмоциональный интеллект и манипуляцию включают в навыки, которыми может обладать человек с высоким уровнем эмоционального интеллекта.

Стоит сделать еще один важный вывод: при увеличении времени и с учетом способа взаимодействия с клиентом роль уровня эмоционального интеллекта при заключении сделки существенно повышается. Также при личном визите эффективность работы сотрудника и степень взаимосвязи существенно выше, чем результаты работы сотрудника без личной встречи с потенциальным клиентом. Продемонстрируем, как изменилась стоимость одного контракта за аналогичный период на исследуемом предприятии. За период с февраля 2018 по июнь 2018 приведем данные по результатам деятельности предприятия ООО «Концепт Кар». Под затратами на маркетинг подразумевались затраты на смс-рассылку, которая проводилась для привлечения клиентского трафика в шоу-рум дилера. Исходя из суммы затрат рассчитывается стоимость одного контакта. Приведем необходимые показатели в таблице 10 ниже. 
Таблица 10.

Показатели деятельности отдела сбыта с марта по июнь 2018

\begin{tabular}{|c|c|c|c|c|c|c|}
\hline $\begin{array}{c}\text { Пери- } \\
\text { од }\end{array}$ & $\begin{array}{c}\text { Уровень } \\
\text { общего } \\
\text { эмоцио- } \\
\text { нального } \\
\text { интел- } \\
\text { лекта }\end{array}$ & $\begin{array}{c}\text { Общее } \\
\text { количе- } \\
\text { ство ви- } \\
\text { зитов } \\
\text { (шт.) }\end{array}$ & $\begin{array}{c}\text { Количе- } \\
\text { ство } \\
\text { кон- } \\
\text { трактов } \\
\text { (шт.) }\end{array}$ & $\begin{array}{c}\text { Конвер- } \\
\text { сия отде- } \\
\text { ла по ви- } \\
\text { зитам } \\
(\%)\end{array}$ & $\begin{array}{c}\text { Затраты } \\
\text { на мар- } \\
\text { кетинг } \\
\text { (руб.) }\end{array}$ & $\begin{array}{c}\text { Стои- } \\
\text { мость } \\
\text { одного } \\
\text { контрак- } \\
\text { та (руб.) }\end{array}$ \\
\hline $\begin{array}{c}\text { Фев- } \\
\text { раль }\end{array}$ & 89 & 72 & 8 & 11 & 28157 & 3520 \\
\hline Март & 89 & 64 & 9 & 14 & 32137 & 3571 \\
\hline $\begin{array}{c}\text { Ап- } \\
\text { рель }\end{array}$ & 103 & 50 & 9 & 19 & 29945 & 3327 \\
\hline Май & 103 & 49 & 11 & 22 & 27167 & 2470 \\
\hline Июнь & 103 & 49 & 13 & 23 & 33251 & 2558 \\
\hline
\end{tabular}

В феврале 2018 средний показатель уровня общего эмоционального интеллекта отдела продаж был 89 пунктов. При этом в шоу-рум пришли 72 человека. Из них 8 уехали на новом автомобиле, или $11 \%$ от общего числа тех, кто пришел в автосалон. Средний уровень общего эмоционального интеллекта с учетом изменений в составе отдела продаж составил 103 пункта. При этом за июнь 2018 в отдел продаж пришли на личную встречу 49 потенциальных покупателей. Из них автомобиль приобрели 13 человек, или $23 \%$ от общего числа позвонивших. При этом стоимость одного контракта для компании уменьшилась на 962 рубля. Конверсия отдела сбыта по визитам выросла на $12 \%$. По итогам оценки влияния уровня общего эмоционального интеллекта на производительность специалиста по продажам можно сделать следующе выводы: во-первых, уровень общего эмоционального интеллекта однозначно играет не последнюю роль в производительности продавца. Можно предположить, что именно этим и отличаются сотрудники, которые при прочих равных условиях показывают совершенно разные результаты. Во-вторых, при росте качества обработки клиентского трафика, за- 
траты на маркетинг могут быть снижены, эффективность использования маркетингового бюджета возрастает, стоимость одного контакта и стоимость одного контракта снижается. В-третьих, процент выполнения плана увеличивается. Как правило, при росте продаж пропорционально увеличивается и прибыль предприятия. Но на практике не все так однозначно, в частности в автомобильном бизнесе. Перейдем к оценке влияния уровня общего эмоционального интеллекта сотрудника на прибыль предприятия.

Анализ влияния уровня общего эмоционального интеллекта сотрудника на прибыль предприятия. Выдвигается гипотеза о наличии взаимосвязи между уровнем общего эмоционального интеллекта сотрудника отдела сбыта и прибылью предприятия. Минимальное значение уровня общего эмоционального интеллекта в выборке 65 пунктов, максимальное - 125 пунктов. Минимальное значение прибыли - 0,1 \%, максимальное - 3,2 \%. Отрицательные значения из выборки были исключены. В результате двумерного анализа очень слабая корреляция наблюдалась изначально, t-набл. - 2,24 больше

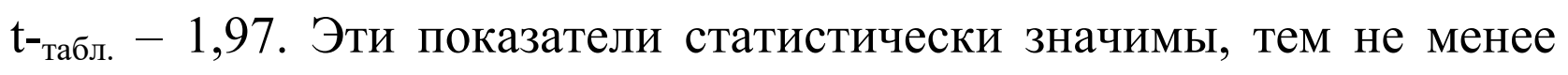
коэффициент детерминации после проведения регрессионного анализа показал очень слабую связь - всего лишь 17 \%. Означает ли это, что можно в данном случае полностью отвергнуть, равно как и принять данную гипотезу? Статистическое основание принять гипотезу есть. Тем не менее сегментировав выборку на две группы, были проведены дополнительные тесты, которые определили, что роль имеет не только уровень общего эмоционального интеллекта сотрудника, но и что именно он реализует: продукцию премиального бренда или продукцию масс бренда. Учитывая разность подходов к конечному ценообразованию отпускной цены, разную динамику по доле рынка, можно полагать, что сотрудники, которые работают в премиальном бренде, могут оказывать минимальное влияние на цену реализации. Так, если взять в расчет только $63 \%$ тех, кто работает в премиальном бренде, можно получить изначально отрицательную корреля- 
цию. То есть эти 17 \% формируются за счет 37 \% опрошенных специалистов, которые работают в масс-бренде. Изучать влияние уровня общего эмоционального интеллекта на выручку нужно в контексте теории ограничений, выявлять «узкие места» в процессе анализа и отдельно рассматривать их. Также существуют различные факторы, которые влияют на процесс формирования конечной отпускной цены для клиента. В автомобильном бизнесе цена на автомобиль формируется часто индивидуально для каждого клиента, особенно в период достаточно непростой ситуации не только в экономике, но и в сфере продажи автомобилей.

Учитывая, что отпускную цену формирует, в большинстве случаев, руководитель отдела продаж, можно смело заявить о том, что менеджер отдела продаж не имеет прямого влияния на отпускную цену, следовательно, и на выручку предприятия. Сотрудник в данном случае может только косвенно повлиять на этот показатель: привести в компанию 10 новых клиентов, таким образом, уменьшив стоимость контракта, сыграть большую роль в выполнении плана продаж, что является результатом экономической деятельности предприятия. Увеличение фактических показателей по продажам способно повлиять на долю рынка, которую занимает предприятие. Но финальное решение и ответственность за финансовый результат работы отдела несет уже руководитель подразделения. В этом случае уровень общего эмоционального интеллекта сотрудника совершенно ни при чем. Для исследования влияния уровня общего эмоционального интеллекта сотрудника на прибыль предприятия непосредственно, рекомендуется проводить исследования в других сферах малого и среднего бизнеса. Например, в небольшом винном магазине, в котором каждого покупателя консультирует специалист-сомелье. Цена на продукт будет фиксирована, скидки, пусть даже по различным бонусным программам в ERP можно будет из генеральной совокупности легко вычленить и считать непосредственно длину чека. В текущей рыночной ситуации проанализировать влияние уровня общего эмоционального интеллекта сотрудника на прибыль 
именно в автомобильном бизнесе достаточно сложно, не имея при этом неограниченного доступа к любым данным внутри структуры коммерческих отделов и не обладая достаточным количеством наблюдений для составления репрезентативной выборки в рамках обозначенных структурных ограничений. Сведем все вышеуказанные полученные данные в одну таблицу 11. Были рассмотрены четыре базовых показателя: влияние уровня общего эмоционального интеллекта сотрудников сбытового отдела на показатели эффективности его работы (выполнение плана продаж, конверсия по визитам и конверсия по звонкам), которые в конечном итоге оказывают влияние на результаты деятельности предприятия.

Таблица 11.

Влияние уровня общего эмоционального интеллекта на результаты экономической деятельности предприятия

\begin{tabular}{|c|c|c|c|c|}
\hline \multirow[b]{2}{*}{ Гипотеза } & \multicolumn{2}{|c|}{ Показатели } & \multirow[b]{2}{*}{ Вывод } & \multirow[b]{2}{*}{$\begin{array}{c}\text { Влияние на } \\
\text { результат эко- } \\
\text { номической } \\
\text { деятельности } \\
\text { предприятия }\end{array}$} \\
\hline & $\begin{array}{c}\text { Значи- } \\
\text { мость } \\
\text { коэффи- } \\
\text { циента } \\
\text { детер- } \\
\text { минации }\end{array}$ & $\begin{array}{c}\text { Коэффи- } \\
\text { циент } \\
\text { детер- } \\
\text { минации, } \\
\text { \% }\end{array}$ & & \\
\hline $\begin{array}{l}\text { Уровень } \\
\text { общего } \\
\text { эмоцио- } \\
\text { нального } \\
\text { интеллекта } \\
\text { влияет на } \\
\text { конверсию } \\
\text { по звонкам }\end{array}$ & 0,000 & 75 & $\begin{array}{l}\text { Гипотеза подтвер- } \\
\text { ждается. Чем выше } \\
\text { уровень эмоцио- } \\
\text { нального интеллек- } \\
\text { та, тем качествен- } \\
\text { нее сотрудник ра- } \\
\text { ботает с первичны- } \\
\text { ми клиентами }\end{array}$ & $\begin{array}{l}\text { Маркетинго- } \\
\text { вая стоимость } \\
\text { одного кон- } \\
\text { такта снижа- } \\
\text { ется. Пред- } \\
\text { приятие со- } \\
\text { кращает рас- } \\
\text { ходы на рек- } \\
\text { ламу }\end{array}$ \\
\hline
\end{tabular}


Окончание Таблицы 11.

\begin{tabular}{|c|c|c|c|c|}
\hline $\begin{array}{l}\text { Уровень } \\
\text { общего } \\
\text { эмоцио- } \\
\text { нального } \\
\text { интеллекта } \\
\text { влияет на } \\
\text { конверсию } \\
\text { по визитам }\end{array}$ & 0,000 & 84 & $\begin{array}{l}\text { Гипотеза подтвер- } \\
\text { ждается. Чем выше } \\
\text { уровень эмоцио- } \\
\text { нального интеллек- } \\
\text { та, тем выше шанс } \\
\text { заключения кон- } \\
\text { тракта с первичны- } \\
\text { ми клиентами }\end{array}$ & $\begin{array}{l}\text { Маркетинго- } \\
\text { вая стоимость } \\
\text { одного кон- } \\
\text { тракта снижа- } \\
\text { ется. Пред- } \\
\text { приятие со- } \\
\text { кращает рас- } \\
\text { ходы на рек- } \\
\text { ламу }\end{array}$ \\
\hline $\begin{array}{l}\text { Уровень } \\
\text { общего } \\
\text { эмоцио- } \\
\text { нального } \\
\text { интеллекта } \\
\text { влияет на } \\
\text { показатели } \\
\text { выполне- } \\
\text { ния инди- } \\
\text { видуально- } \\
\text { го плана } \\
\text { продаж }\end{array}$ & 0,000 & 61 & $\begin{array}{l}\text { Гипотеза подтвер- } \\
\text { ждается. Чем выше } \\
\text { уровень эмоцио- } \\
\text { нального интеллек- } \\
\text { та, тем выше шанс } \\
\text { заключения кон- } \\
\text { тракта с клиентами }\end{array}$ & $\begin{array}{l}\text { Прибыль } \\
\text { предприятия } \\
\text { увеличивается } \\
\text { Сокращаются } \\
\text { расходы на } \\
\text { содержание } \\
\text { запасов } \\
\text { Возможны } \\
\text { финансовые } \\
\text { бонусы от } \\
\text { производителя }\end{array}$ \\
\hline $\begin{array}{l}\text { Уровень } \\
\text { общего } \\
\text { эмоцио- } \\
\text { нального } \\
\text { интеллекта } \\
\text { влияет на } \\
\text { показатели } \\
\text { по прибыли }\end{array}$ & 0,010 & 17 & $\begin{array}{l}\text { Гипотеза подтвер- } \\
\text { ждается частично. } \\
\text { Поскольку имеет } \\
\text { структурные проти- } \\
\text { воречия, основан- } \\
\text { ные на ограничени- } \\
\text { ях, которые могут } \\
\text { быть в выборке }\end{array}$ & $\begin{array}{l}\text { Прибыль } \\
\text { предприятия } \\
\text { увеличивается } \\
\text { (в зависимости } \\
\text { от типа пред- } \\
\text { приятия) } \\
\text { Сокращаются } \\
\text { расходы на } \\
\text { содержание } \\
\text { запасов }\end{array}$ \\
\hline
\end{tabular}


Из таблицы следует, что уровень общего эмоционального интеллекта оказывает влияние на эффективность работы сотрудников и, как косвенное следствие, на экономические результаты деятельности предприятия. Эффективность работы сотрудника при каждом входящем звонке в 75 \% определяется уровнем общего эмоционального интеллекта, эффективность работы сотрудника при личной встрече в 85 \% случаев объясняется уровнем общего эмоционального интеллекта. Хоть это и влияет на выполнение индивидуального плана продаж и его выполнение объясняется на 61 \%, вопрос достижения плановых цифр сам по себе состоит из множества ограничений. А верно ли был поставлен план продаж изначально? Если даже у сотрудника уровень общего эмоционального интеллекта максимальный в отделе, то он никак не достигнет плановых цифр продать 20 автомобилей с 01 по 10 января стоимостью от 2 млн руб. в поселке городского типа. Выполняется ли план продаж по отделу в целом? Какова динамика выполнения плана продаж и соответствует ли коэффициент вариации порогу в 33 \% для анализа средних относительных показателей выполнения плана?

Сегментировав опрошенных по двум группам: премиум-бренд и масс-бренд, - были выявлены некоторые особенности. Изучались два показателя: уровень общего эмоционального интеллекта и относительный показатель выполнения плана продаж на основании результатов опроса. Результаты исследований кратко представлены в таблице 12.

Таблица 12.

Оценка влияния уровня общего эмоционального интеллекта на коэффициент выполнения плана продаж

\begin{tabular}{|l|c|c|}
\hline \multicolumn{1}{|c|}{ Показатель } & $\begin{array}{c}\text { Сегмент автомоби- } \\
\text { лей премиум-бренда }\end{array}$ & $\begin{array}{c}\text { Сегмент автомоби- } \\
\text { лей масс-бренда }\end{array}$ \\
\hline $\mathrm{t}-$ табл. $-\mathrm{t}-$ набл. & $4,47-1,98$ & $9,37-1,99$ \\
\hline
\end{tabular}


Окончание Таблицы 12.

\begin{tabular}{|l|c|c|}
\hline $\begin{array}{l}\text { Коэффициент детермина- } \\
\text { ции (\%) }\end{array}$ & 48,00 & 77,00 \\
\hline $\begin{array}{l}\text { Значимость коэффициента } \\
\text { детерминации }\end{array}$ & 0,02 & 0,00 \\
\hline
\end{tabular}

В обоих случаях прослеживается t-табличное выше, чем tнаблюдаемое, изучаемая взаимосвязь показателей статистически значима. Тем не менее в премиум-сегменте только в $48 \%$ случаев можно объяснить зависимость выполнения плана от уровня общего эмоционального интеллекта, в то время как в масс-сегменте в 77 \% случаев успешность сотрудника действительно определяется уровнем его общего эмоционального интеллекта. Даже значимость коэффициента детерминации в первом случае близка к пограничному значению в 0,05, а во втором случае значимость коэффициента детерминации прослеживается более явно. Сравним еще два параметра: коэффициент вариации, который был получен при анализе расчета средних значений по выполнению плана продаж в выборке. Данные представлены в таблице 13 ниже.

Таблица 13.

Коэффициент вариации в исследовании коэффициента выполнения плана продаж

\begin{tabular}{|l|c|c|}
\hline \multicolumn{1}{|c|}{ Показатель } & $\begin{array}{c}\text { Сегмент автомо- } \\
\text { билей премиум- } \\
\text { бренда, \% }\end{array}$ & $\begin{array}{c}\text { Сегмент автомо- } \\
\text { билей масс- } \\
\text { бренда, \% }\end{array}$ \\
\hline Коэффициент вариации min & 27 & 21 \\
\hline Коэффициент вариации max & 51 & 34 \\
\hline $\begin{array}{l}\text { Коэффициент вариации (сред- } \\
\text { нее значение по выборке) }\end{array}$ & 31 & 22 \\
\hline
\end{tabular}


Следует отметить, что большинство анкет пришлось элиминировать из выборки ввиду большого значения коэффициента вариации при выводе средних показателей. Данные в таблице были предоставлены не по 189 людям, попавшим в выборку, а по всей сумме проанкетированных. Как следует из таблицы, данные, которые были получены в ходе исследования сотрудников, занятых в масссегменте, чаще удовлетворяли показателям на статистическую значимость. При переносе статистического значения в практическое эти сотрудники обладали большим показателем стабильности при выполнении плана. Можно также сделать вывод, что сам план продаж был поставлен корректно, и его тотальное невыполнение больше расценивалось как исключение, нежели как правило. В случае с премиум-сегментом все сложнее - коэффициент вариации в некоторых случаях поражает, особенно когда речь идет о планировании продаж. Отклонения от заданных планов не должны превышать более $10-15 \%$, если же невыполнение плана продаж более $15 \%$, то это указывает на изначально некорректное планирование. 51 \% - большой показатель вероятного отклонения от среднего в контексте грамотного планирования либо отсутствия такового. Эмоциональный интеллект, естественно, оказывает влияние на выполнение плана продаж, но сила этого влияния сопоставима с показателями и по отрасли в целом, и по существующим в компании подходам к планированию, анализу эффективности деятельности, возможности сотрудника влиять на ценообразование и так далее.

Анализ влияния структурных элементов эмоционального интеллекта сотрудников на результаты деятельности. Как известно, в структуру эмоционального интеллекта входят межличностный и внутриличностный виды. Межличностный эмоциональный интеллект отвечает за эффективность коммуникации с другими людьми и позволяет говорить об уровне понимания эмоций других людей и управления ими. Внутриличностный эмоциональный интеллект отвечает за умение человека контролировать и понимать свои собст- 
венные эмоции. Рассмотрим вкратце влияние внутриличностного эмоционального интеллекта на коэффициент выполнения индивидуального плана по продажам. Был проведен корреляционный анализ, в результате которого были получены следующие данные: - $_{\text {набл. - }}$ 2,04 при значении $\mathrm{t}$-табл. 1,97 дает основания полагать, что взаимосвязь показателей статистически значима, и подтвердить гипотезу о том, что уровень внутриличностного эмоционального интеллекта оказывает влияние на коэффициент выполнение индивидуального ежемесячного плана по продажам. Значение коэффициента детерминации составило 0,14, и такой коэффициент статистически значим. Это значит, что в 14 \% случаев выполнение индивидуального плана по продажам объясняется уровнем внутриличностного эмоционального интеллекта. Хоть связь и достаточно слабая, тем не менее можно говорить о том, что управление своими эмоциями, понимание их и контроль над силой проявления влияет на профессиональную деятельность сотрудника сбытового отдела. Первичные результаты исследования взаимосвязи уровня межличностного эмоционального интеллекта и показателей производительности труда сотрудников отделов сбыта показали наличие намного более сильной связи двух признаков, чем в случае с уровнем внутриличностного эмоционального интеллекта. В связи с этим рассмотрим указанный структурный элемент подробнее.

Анализ влияния уровня межличностного эмоционального интеллекта сотрудников на коэффищиент выполнения индивидуального плана по продажам. Межличностный интеллект включает в себя понимание и управление эмоциями других людей. Эти навыки являются одними из ключевых для тех, кто трудоустроен и развивается в сфере продажи товаров и услуг. Умение считывать вербальные и невербальные признаки склонности потенциального покупателя к действиям может помочь в корректировке предполагаемого пути клиента. 
Была выдвинута следующая гипотеза: чем выше уровень межличностного эмоционального интеллекта сотрудника отдела сбыта, тем выше коэффициент выполнения индивидуального плана по продажам. Минимальное значение уровня межличностного эмоционального интеллекта в выборке - 26 пунктов, максимальное - 61 пунктов. Минимальное значение коэффициента выполнения ежемесячного индивидуального плана по продажам - 60 \%, максимальное 142 \%. Представим взаимосвязь данных показателей на рисунке 6.

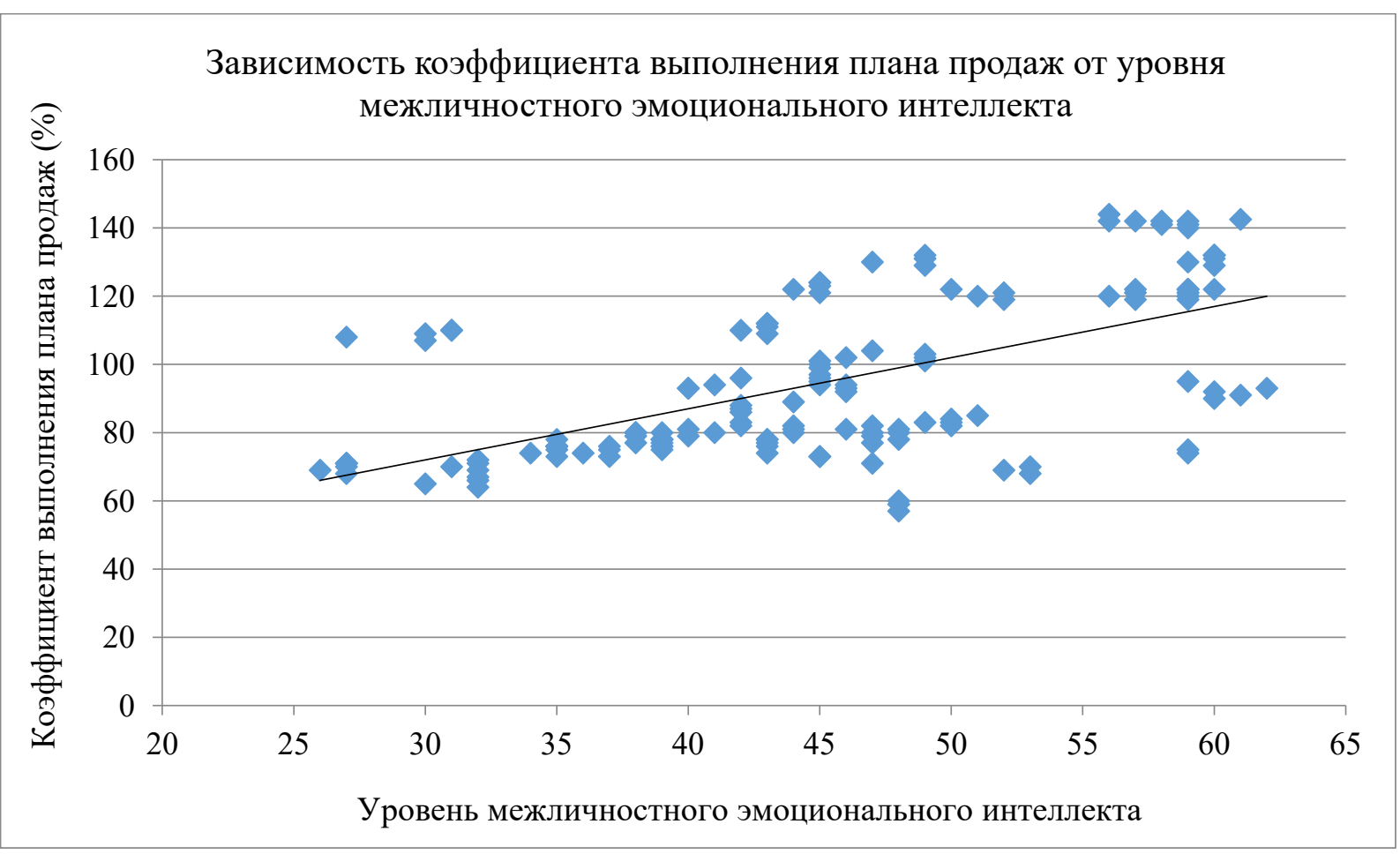

Рисунок 6. Зависимость коэффициента выполнения плана продаж от уровня межличностного эмоционального интеллекта

На графике визуально можно увидеть связь между этими двумя показателями. В результате были получены следующие данные: корреляция Пирсона - 0,62, коэффициент статистически значим ( $\mathrm{t}_{\text {набл. }}-$ $9,68, \mathrm{t}_{\text {табл. }}-1,97$. Наблюдаемое значение превышает табличное с вероятностью ошибки $<5 \%$ ). Гипотеза о том, что выполнение ежемесячного индивидуального плана по продажам зависит от уровня межличностного эмоционального интеллекта. Был проведен регрес- 
сионный анализ, в результате которого был получен статистически значимый коэффициент детерминации 0,37. Таким образом, изменение в проценте выполнения индивидуального плана продаж на 37 \% объясняется уровнем межличностного эмоционального интеллекта.

Межличностный эмоциональный интеллект влияет на выполнение плана продаж. Он также влияет и на эффективность работы сотрудника по воронке продаж, так, по результатам исследования, конверсия при работе с первичным телефонным трафиком на $41 \%$ зависит от межличностного эмоционального интеллекта. При личном же общении с потенциальными покупателями успешное завершение сделки в $49 \%$ случаев зависит от уровня межличностного эмоционального интеллекта. Соответственно, чем выше уровень межличностного эмоционального интеллекта, тем больше производительность труда менеджера по продажам. Что более важно для сотрудника в таком случае? Умение понимать эмоции потенциального покупателя или же умение управлять ими?

Анализ влияния уровня понимания эмоциий на коэффицииент выполнения индивидуального плана по продажам. Понимание эмоций усиливает социальную чуткость. Если, предположим, покупатель выражает согласие, но его невербальные признаки в момент выражения согласия говорят об обратном, то сотрудник может это распознать и вывести клиента на разговор, чтобы выявить причину сомнения и преодолеть возражения. Способность к пониманию эмоций означает, что человек в состоянии не только выявить факт наличие эмоции, но и дать ей описание. Что наиболее важно, так это то, что такой человек понимает не только истоки возникновения эмоций, но и последствия, к которым та или иная эмоция может привести.

Была выдвинута следующая гипотеза: чем выше уровень понимания эмоций сотрудником отдела сбыта, тем выше коэффициент выполнения индивидуального плана по продажам. Минимальное значение уровня понимания эмоций в выборке - 30 пунктов, макси- 
мальное - 60 пунктов. Минимальное значение коэффициента выполнения ежемесячного индивидуального плана по продажам - 60 \%, максимальное - 142 \%. Представим взаимосвязь данных показателей на рисунке 7.

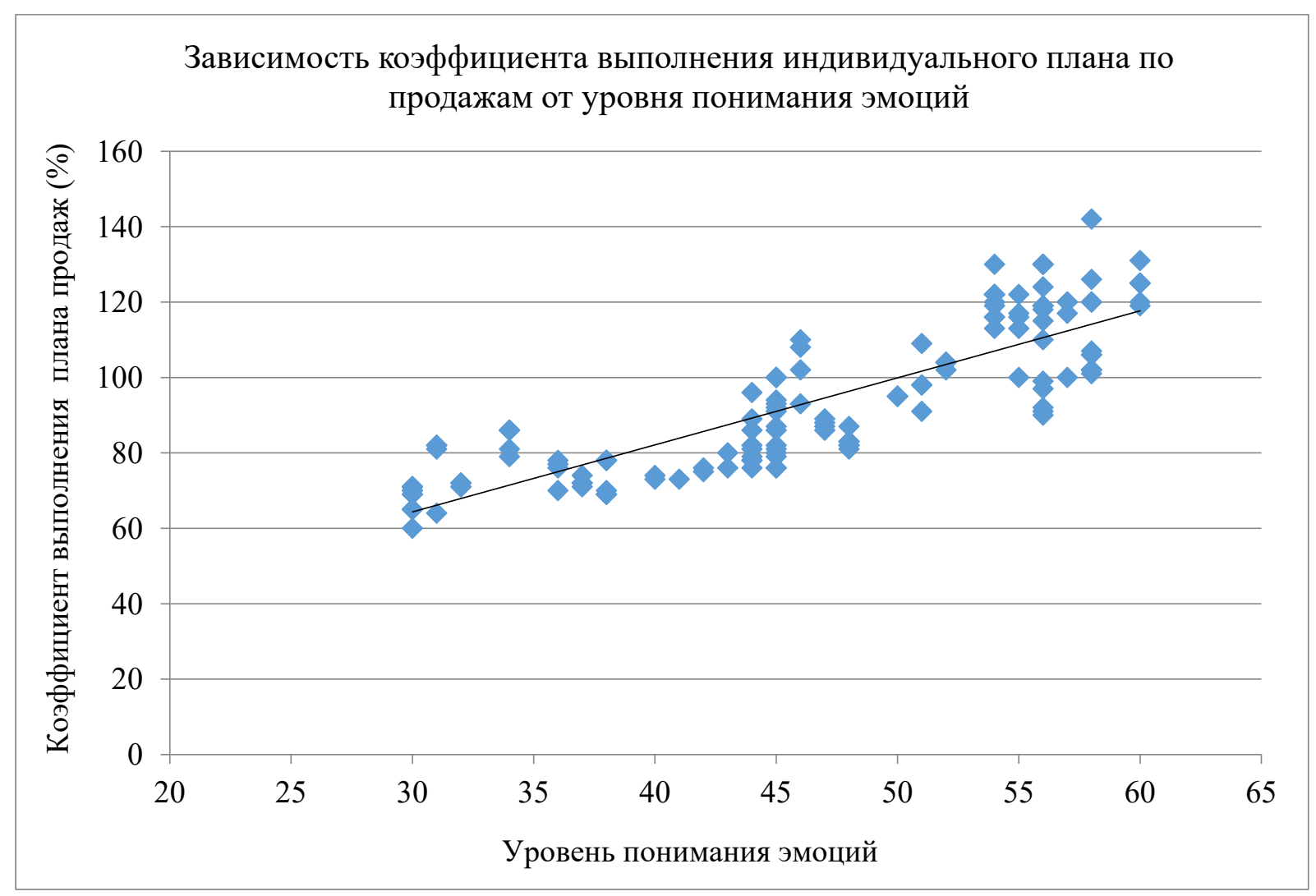

Рисунок 7. Зависимость коэффициента выполнения индивидуального плана по продажам от уровня понимания эмоций

В результате были получены следующие данные: корреляция Пирсона - 0,85, коэффициент статистически значим ( $\mathrm{t}$-набл. $-20,36$,

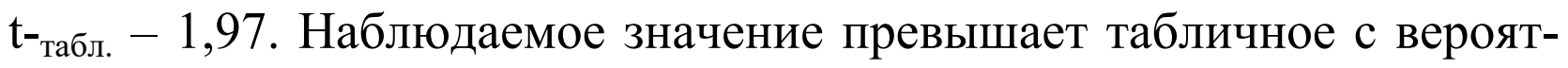
ностью ошибки $<5 \%$ ). Гипотеза о том, что выполнение ежемесячного индивидуального плана по продажам зависит от уровня понимания эмоций, подтверждается. Был проведен регрессионный анализ взаимосвязи показателей, в результате которого был получен статистически значимый коэффициент детерминации 0,65. Таким образом, изменение в проценте выполнения индивидуального плана про- 
даж на 65 \% объясняется уровнем понимания эмоций. Это также означает, что понимание эмоций обуславливает в большей степени влияние уровня общего эмоционального интеллекта на выполнение индивидуального плана по продажам.

Безусловно, не все зависит от этого показателя, и необходимо делать существенную поправку на условия, в которых работает сотрудник и те сферы, на которые он имеет непосредственное влияние, для того, чтобы использовать как можно больше ресурсов, чтобы склонить потенциального покупателя к сделке. Что, в свою очередь, окажет положительное влияние на экономические результаты деятельности предприятия. Рассмотрим, на каком же этапе работы сотрудника, уровень понимания эмоций играет наиболее важную роль и в каких случаях взаимосвязь между пониманием эмоций и эффективность наиболее сильна.

Анализ влияния уровня понимания эмочий на показатель конверсии по звонкам. Уже по телефонному разговору сотрудник с развитыми компетенциями в области понимания эмоций может оценить, как минимум степень заинтересованности клиента и степень его готовности вести конструктивный диалог о покупке товара. По тембру голоса и темпу речи сотрудник с более высоким уровнем эмоционального интеллекта способен предугадать настроение человека без личного контакта и, возможно, даже как-то скорректировать его в нужное русло.

Была выдвинута следующая гипотеза: чем выше уровень понимания эмоций сотрудником отдела сбыта, тем выше показатель конверсии сотрудника отдела сбыта по звонкам. Минимальное значение уровня понимания эмоций в выборке - 30 пунктов, максимальное 60 пунктов. Минимальное значение показателя конверсии по звонкам сотрудника по продажам - 1 \%, максимальное - 24 \%. Представим взаимосвязь двух показателей на рисунке 8. 


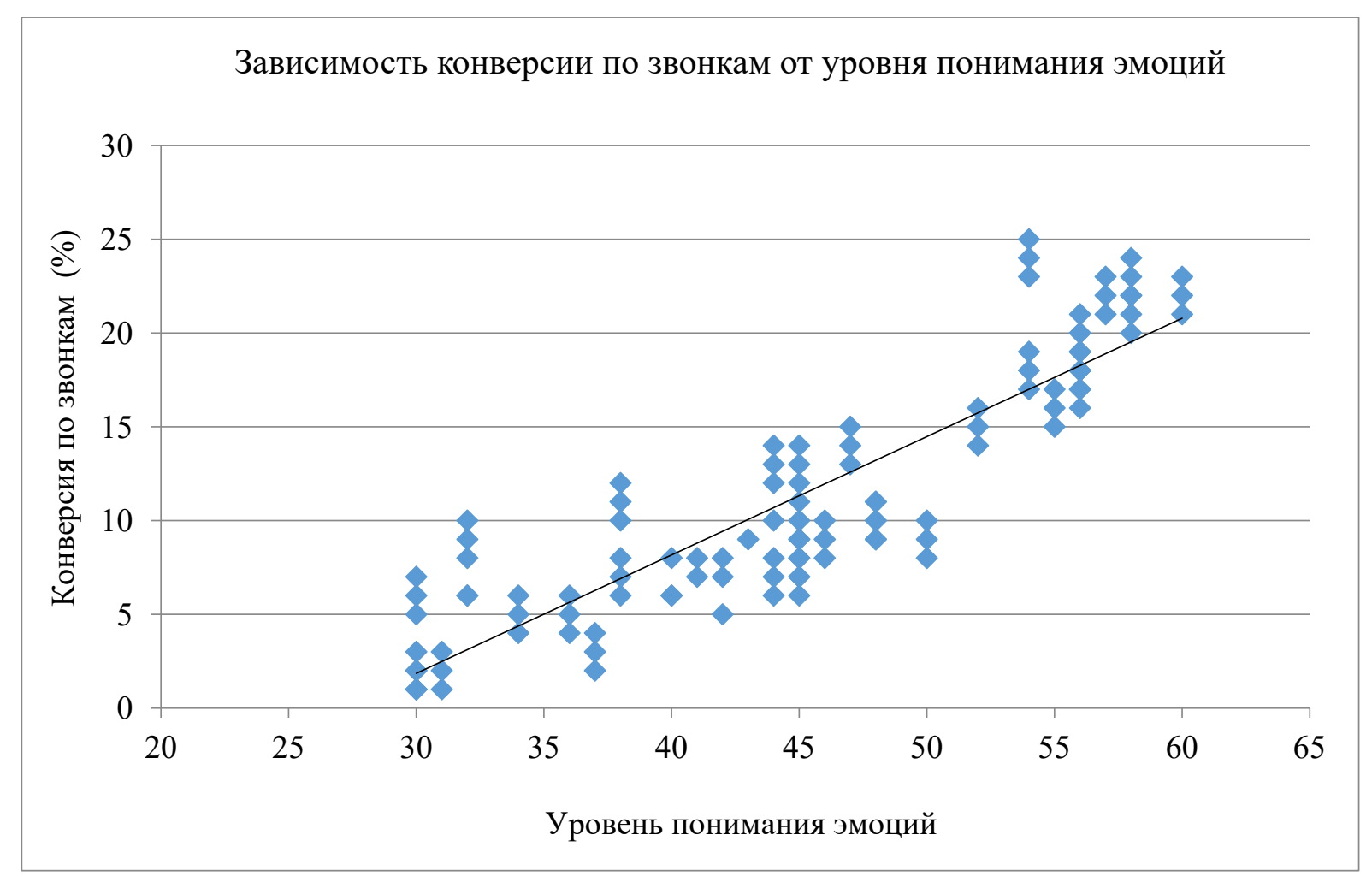

Рисунок 8. Зависимость конверсии по звонкам от уровня понимания эмоций

В результате были получены следующие данные: корреляция Пирсона - 0,89, коэффициент статистически значим ( $\mathrm{t}$ набл. $_{\text {на }}-20,84$,

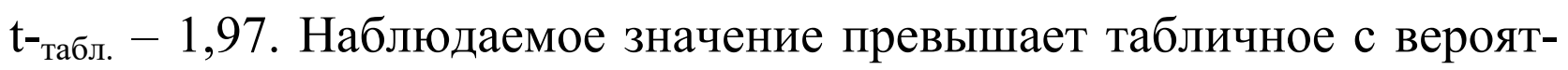
ностью ошибки <5 \%). Можно подтвердить гипотезу о том, что уровень понимания эмоций влияет на значение показателя конверсии по первичным звонкам. Коэффициент детерминации - 80, который является также статистически значимым, позволяет сделать вывод, что шанс того, что потенциальный покупатель после первого телефонного звонка в компанию придет с личным визитом к сотруднику отдела продаж, на 80 \% зависит от уровня понимания эмоций. Во время первичного общения по телефону сотрудник уже может оценить потенциального потребителя, выявить заинтересованность в продукте и склонить к личной встрече. Он может также продемонстрировать свою клиентоориентированность, сделать так, чтобы потенциальный потребитель почувствовал уверенность в том товаре, который ему 
предлагают, и что у сотрудника предприятия нет желания навязать невыгодную сделку. Сотрудник с высоким уровнем понимания эмоций имеет все шансы создать у клиента положительный имидж компании. Для предприятия каждый пришедший в компанию клиент это шанс реализовать товар, который она предлагает на рынке. Также каждый пришедший в компанию человек позволяет оценить эффективность использования рекламных инструментов и снизить стоимость взаимодействия, о чем уже говорилось выше. Рассмотрим, как изменится влияние уровня понимания эмоций при личной встрече потенциального клиента и менеджера по продажам.

Анализ влияния уровня понимания эмочиий на показатель конверсии по визитам. При личном обращении потенциального клиента в компанию количество точек приложения талантов менеджера по продажам возрастает. Оценить поведение потребителя теперь можно не только по голосу, но и по совокупности других признаков: движения, мимика, поза, в которой стоит человек, и так далее. Можно заметить на лице потенциального покупателя едва заметные изменения, когда он выражает свое согласие или несогласие. Рассмотрим, насколько велико влияние уровня понимания эмоций на умение менеджера по продажам трансформировать встречи с клиентом в совершенные сделки и результат компании. Исследовались два показателя: уровень общего эмоционального интеллекта и значение показателя конверсии по визитам. Была выдвинута гипотеза о влиянии уровня общего эмоционального интеллекта на показатель конверсии по визитам. Минимальное значение уровня общего эмоционального интеллекта в выборке - 65 пунктов, максимальное - 125 пунктов. Минимальное значение показателя конверсии по визитам - 12 \%, максимальное - 45 \%. Представим взаимосвязь показателей на рисунке 9. 


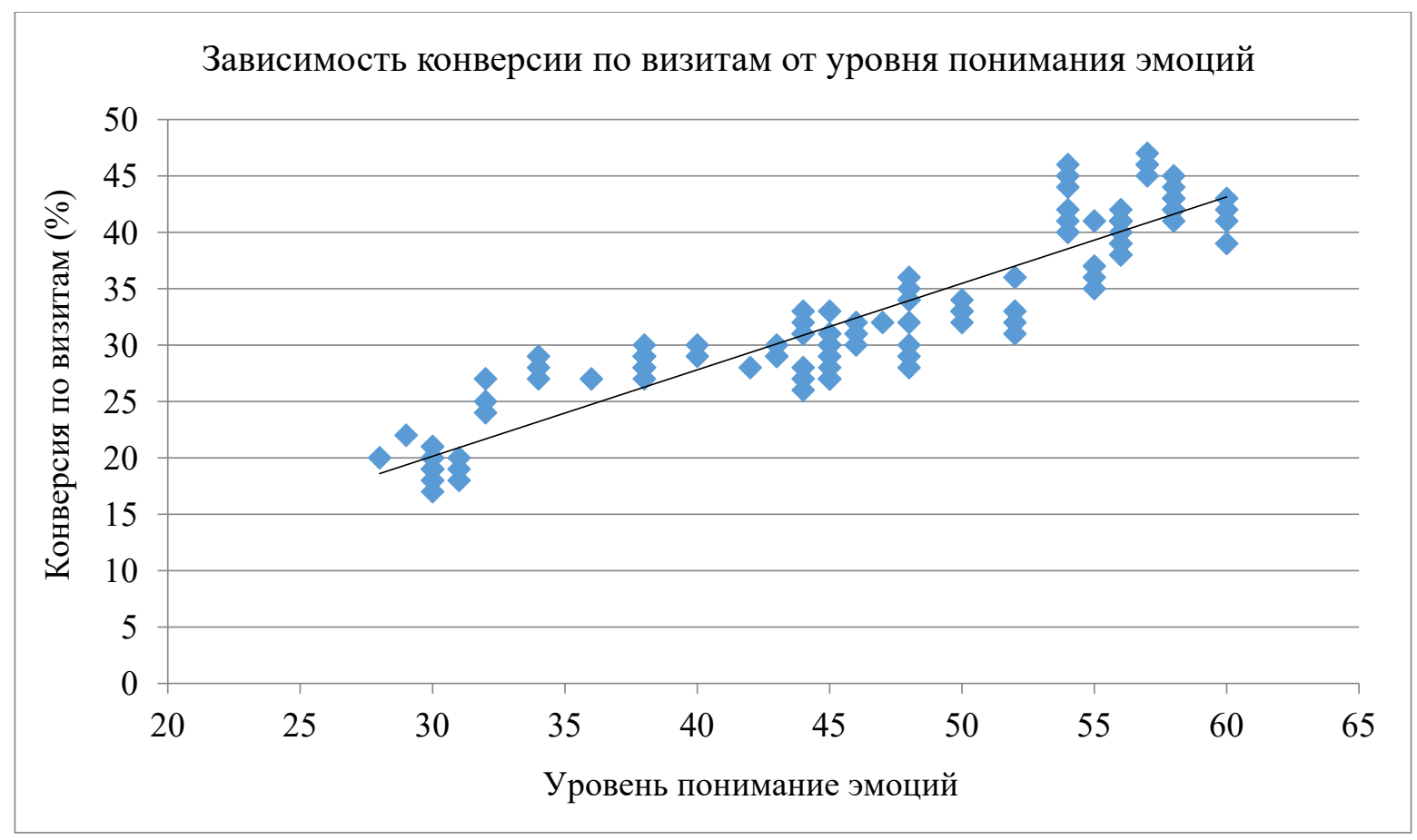

Рисунок 9. Зависимость конверсии по визитам от уровня понимания эмоций

В результате были получены следующие данные: корреляция Пирсона - 0,92, коэффициент статистически значим ( $\mathrm{t}_{\text {набл. }}-27,58$,

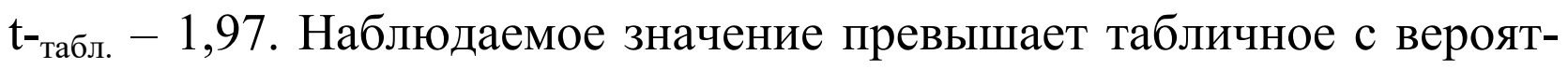
ностью ошибки $<5$ \%). Можно принять гипотезу о том, что показатель конверсии по визитам зависит от уровня понимания эмоций, который присутствует в структуре эмоционального интеллекта сотрудника отдела сбыта. Коэффициент детерминации, который был получен в ходе проведения регрессионного анализа, статистически значим и составляет 0,86. Таким образом, изменение в проценте продаж, которые были совершены в результате обращения потребителя лично, на 86 \% объясняется уровнем понимания эмоций. Чтобы сделать окончательный вывод о том, что все-таки влияет на успешность продавца и, как следствие, на улучшение результатов экономической деятельности предприятия, необходимо оценить и влияние уровня управления эмоциями на все три главные составляющие в определении эффективности деятельности сотрудника по продажам. В шкалу управления эмоциями входят две субшкалы: управление 
эмоциями других людей (МУ) и управление своими собственными эмоциями (ВУ). Представим полученные данные в таблице 14.

Таблица 14.

Влияние компонент структурного элемента управления эмоциями на эффективность работы сотрудника отдела продаж

\begin{tabular}{|l|c|c|c|}
\hline \multicolumn{1}{|c|}{ Гипотеза } & \multicolumn{3}{|c|}{ Показатели } \\
\cline { 1 - 4 } & $\begin{array}{c}\text { Значимость } \\
\text { коэффициен- } \\
\text { та детерми- } \\
\text { нация }\end{array}$ & $\begin{array}{c}\text { Коэффи- } \\
\text { циент } \\
\text { детер- } \\
\text { минации }\end{array}$ & $\begin{array}{c}\text { t- наблю- } \\
\text { даемое - } \\
\text { t- таб- } \\
\text { личное }\end{array}$ \\
\hline $\begin{array}{l}\text { ВУ влияет на выполнение } \\
\text { плана продаж }\end{array}$ & 0,006 & 0,20 & $5,66>1,9$ \\
\hline $\begin{array}{l}\text { ВУ влияет на конверсию } \\
\text { по звонкам }\end{array}$ & 0,006 & 0,20 & $5,67>1,9$ \\
\hline $\begin{array}{l}\text { ВУ влияет на конверсию } \\
\text { по визитам }\end{array}$ & 0,000 & 0,30 & $7,35>1,9$ \\
\hline $\begin{array}{l}\text { МУ влияет на выполнение } \\
\text { плана продаж }\end{array}$ & 0,005 & 0,20 & $5,75>1,9$ \\
\hline $\begin{array}{l}\text { МУ влияет на конверсию } \\
\text { по звонкам }\end{array}$ & 0,000 & 0,29 & $7,21>1,9$ \\
\hline $\begin{array}{l}\text { МУ влияет на конверсию } \\
\text { по визитам }\end{array}$ & 0,001 & 0,27 & $6,95>1,9$ \\
\hline $\begin{array}{l}\text { УЭ влияет на выполнение } \\
\text { плана продаж }\end{array}$ & 0,41 & $9,47>1,9$ \\
\hline УЭ влияет конверсию по звонкам & 0,22 & $6,07>1,9$ \\
\hline УЭ влияет конверсию по визитам & 0,003 & 0,15 \\
\hline
\end{tabular}


Изучив информацию в таблице, можно сделать выводы: вопервых, все элементы управления эмоциями являются статистически значимыми (во всех случаях табличное ниже наблюдаемого), вовторых, коэффициент детерминации во всех случаях также является статистически значимым. Выполнение плана продаж в 22 \% случаев можно объяснить уровнем управления эмоциями. Причем управление эмоциями других людей (коэффициент детерминации - 0,15) меньше коррелирует с коэффициентом выполнения индивидуального плана по продажам, чем управление своими эмоциями (коэффициент детерминации - 0,20). Уровень показателя конверсии по звонкам на 27 \% объясняется уровнем управления эмоциями. При этом влияние управления собственными эмоциями (коэффициент детерминации - 0,20) равнозначен управлению эмоциями других людей (коэффициент детерминации - 0,20). Уровень общего управления эмоциями на 41 \% объясняет эффективность работы сотрудника при личной встрече с потенциальным клиентом, при этом и уровень управления своими эмоциями, и уровень управления эмоциями других людей практически равнозначны. Как выяснилось, понимание эмоций играет намного большую роль в процессе продаж товаров и услуг, чем управление ими. Конечно, чтобы дать ответ на вопрос почему, нужны дополнительные исследования и данный вопрос уже лежит больше в области психологии. Тем не менее можно предположить логическое объяснение: как можно управлять тем, чего не понимаешь. Вполне возможно, что чем выше уровень понимания эмоций, тем выше и уровень управления ими, но центральное значение все же обретает первая способность.

Проведя всесторонний анализ влияния уровня эмоционального интеллекта и его компонентов на результаты деятельности сотрудников отела сбыта, можно с уверенностью сказать, что эмоциональный интеллект является детерминантом высокой производительности труда сотрудника отдела продаж. Также сотрудники, у которых выше уровень эмоционального интеллекта, больше других отлича- 
ются стабильностью в выполнении плановых показателей при прочих равных условиях. Поскольку, как уже было установлено, на уровень результативности сотрудника влияет еще комплекс внешних и внутренних факторов, таких как, например, область деятельности предприятия, структурные особенности и регламенты предприятия в вопросах ценообразования и делегирования полномочий. Данное исследование продемонстрировало весь комплекс факторов, которые подтверждают неотъемлемую часть успешности сотрудника, которая обусловлена уровнем эмоционального интеллекта, что в свою очередь косвенно доказывает и влияние уровня эмоционального интеллекта на результаты деятельности предприятия. Далее оценим степени влияния эмоционального интеллекта на экономические результаты деятельности предприятий.

\section{2. Анализ влияния эмоционального интеллекта} на экономические результаты на примере ООО «Концепт Кар»

Для того чтобы оценить влияние эмоционального интеллекта на экономические результаты деятельности предприятия, в опросе принимали участие не только действующие сотрудники предприятия, которое взято для проведения такой оценки, но и другие члены отдела сбыта, которые уже не работают на этом предприятии. Это необходимо для того, чтобы можно было, во-первых, проследить динамику изменения среднего уровня общего эмоционального интеллекта по сбытовому отделу продаж и сравнить эти данные помесячно с результатами экономической деятельности предприятия.

Исследование проводилось на предприятии ООО «Концепт Кар». В качестве исследуемого периода взяты данные с 2015 по 2018 год включительно. Предприятие на рынке с 2004 года и занимается продажей и ремонтом легковых автомобилей премиум и 
среднего класса. Предприятие относится к средним, численность сотрудников на предприятии более 100 человек. В отделе продаж работают 6 менеджеров, 1 руководитель отдела и 1 логист. Все сотрудники, которые ныне работают и ранее были трудоустроены в отделе продаж новых автомобилей прошли опрос на определение уровня эмоционального интеллекта. Данные сотрудники вошли в состав общей выборки, которая уже была описана выше. Для выполнения оценки, которую предусматривает этот раздел работы, соответствующие сотрудники были выделены в группу из сформированной выборки по принципу принадлежности к одному отделу продаж.

В качестве основных показателей результатов экономической деятельности предприятия для проведения оценки были взяты показатели: выручка, прибыль от продаж, рентабельность продаж, объем продаж новых автомобилей в штуках, коэффициент выполнения плана продаж отделом и доля рынка. В первую очередь оценим влияние уровня эмоционального интеллекта отдела продаж на коэффициент выполнения плана продаж по отделу.

Оиченка влияния уровня общегго эмоциионального интеллекта отдела продаж на коэффицичент выполнения ежемесячного плана продаж. Минимальное значение уровня общего эмоционального интеллекта в выборке - 86 пунктов, максимальное - 106 пунктов. Минимальное значение коэффициента выполнения ежемесячного индивидуального плана по продажам - $92 \%$, максимальное - $103 \%$. Представим взаимосвязь данных показателей на рисунке 10. Сезонный компонент отсутствует. 


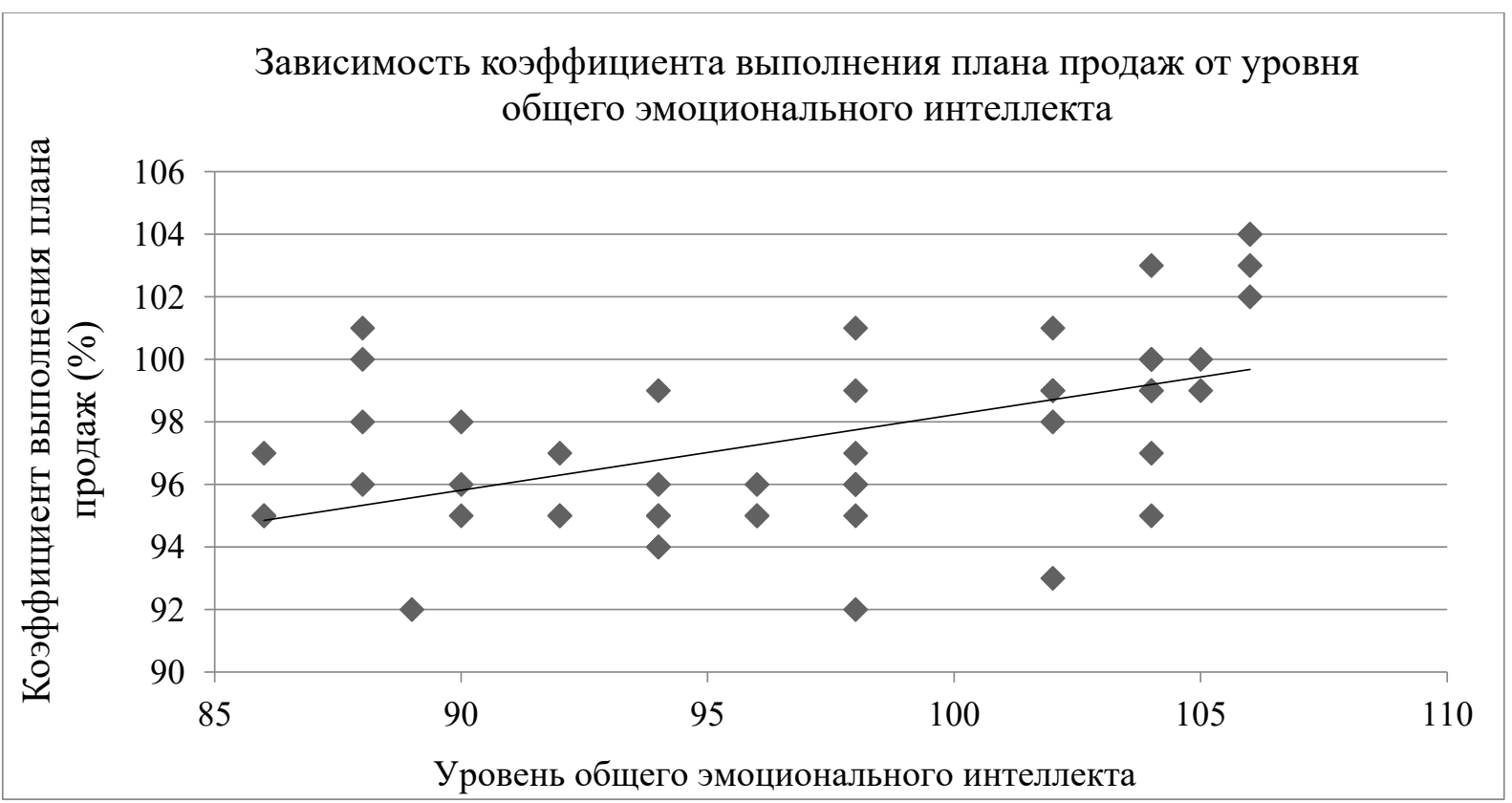

Рисунок 10. Зависимость коэффициента выполнения плана продаж от уровня общего эмоционального интеллекта

Визуально можно сделать вывод о том, что связь, хоть и слабая, но все же присутствует. Во-первых, уровень эмоционального интеллекта по отделу менялся не каждый месяц и не скачкообразно, вовторых, коэффициенты выполнения плана по отделу тоже в принципе находятся ориентировочно в одном узком диапазоне. Был проведен корреляционный анализ количественных признаков. В результате были получены следующие данные: корреляция Пирсона - 0,51, коэффициент статистически значим ( $\mathrm{t}_{\text {-набл. }}-4,10, \mathrm{t}_{\text {табл. }}-2,11$. Наблюдаемое значение превышает табличное с вероятностью ошибки $<5 \%$ ). Можно сделать вывод о том, что связь показателей статистически значима и подтвердить гипотезу о том, что с повышением уровня общего эмоционального интеллекта увеличивается, и процент выполнения или даже перевыполнения ежемесячного общего плана отдела по продажам. Значение коэффициента детерминации по результатам регрессионного анализа $-0,32$, и он статистически значим. Таким образом, изменение в проценте выполнения ежемесячного плана продаж по отделу на 32 \% объясняется уровнем эмоционального интеллекта в отделе продаж. 
Такая разница между индивидуальными показателями сотрудников и показателями по отделу может быть обусловлена следующими причинами:

- во-первых, за основу для проведения оценки взят отдел продаж, который занимается реализацией автомобилей премиум-класса. Как было уже указано ранее, результаты на примере разных брендов могут качественно отличаться. Премиум-бренд отличается крайней нестабильностью в продажах и отсутствием возможности с адекватной долей вероятности прогнозировать спрос будущих периодов, в связи с чем и появляются частые расхождения плановых цифр с фактическими. В премиум-бренде на лицо ошибка планирования. Тем не менее даже в таких условиях можно объяснить результативность отдела сбыта на $14 \%$ уровнем эмоционального интеллекта сотрудников. Можно предположить, что в отделах продаж с более стабильным уровнем покупательской способности коэффициент детерминации будет существенно выше;

- во-вторых, большую роль играет и ценообразование на автомобили, которые определяет не сотрудник и не руководитель, а директор предприятия. Так, учитывая нестабильную обстановку в продажах такой ценовой категории, от отпускных цен с учетом скидок и зависит выполнение плана продаж. Именно этим и объясняются разные точки на графике. Так, например, при уровне эмоционального интеллекта отдела в 98 пунктов минимальное значение выполнения плана составило $92 \%$, а максимальное - $101 \%$. Для ответа на этот вопрос необходимо анализировать месяц, когда именно такие результаты были получены. 101 \% выполнения плана обеспечили скидки, которые согласовал директор предприятия для закрытия квартала и получения поквартальных бонусов от производителя. А $92 \%$ наблюдалось в первом месяце квартала, когда на первое место вышла задача повышения доходности, а не выполнения плановых значений после закрытия квартала. Комплекс таких факторов обуславливает не 
только результативность сбытового отдела в дилерском центре, но и сравнительно низкую взаимосвязь между уровнем эмоционального интеллекта и коэффициентом выполнения плана продаж на примере данного предприятия. Оценим далее не коэффициент выполнения плана, а штуки.

Оценка влияния уровня общего эмочионального интеллекта отдела продаж на количество проданных автомобилей. Данные по объему продаж были предоставлены за 4 года: с 2015 по 2018 год включительно. Минимальное значение уровня общего эмоционального интеллекта в выборке - 86 пунктов, максимальное - 106 пунктов. Минимальное значение объема продаж в штуках - 14, максимальное - 26. Для начала необходимо очистить данные по продажам от сезонности. Построим график по имеющимся данным (рисунок 11).

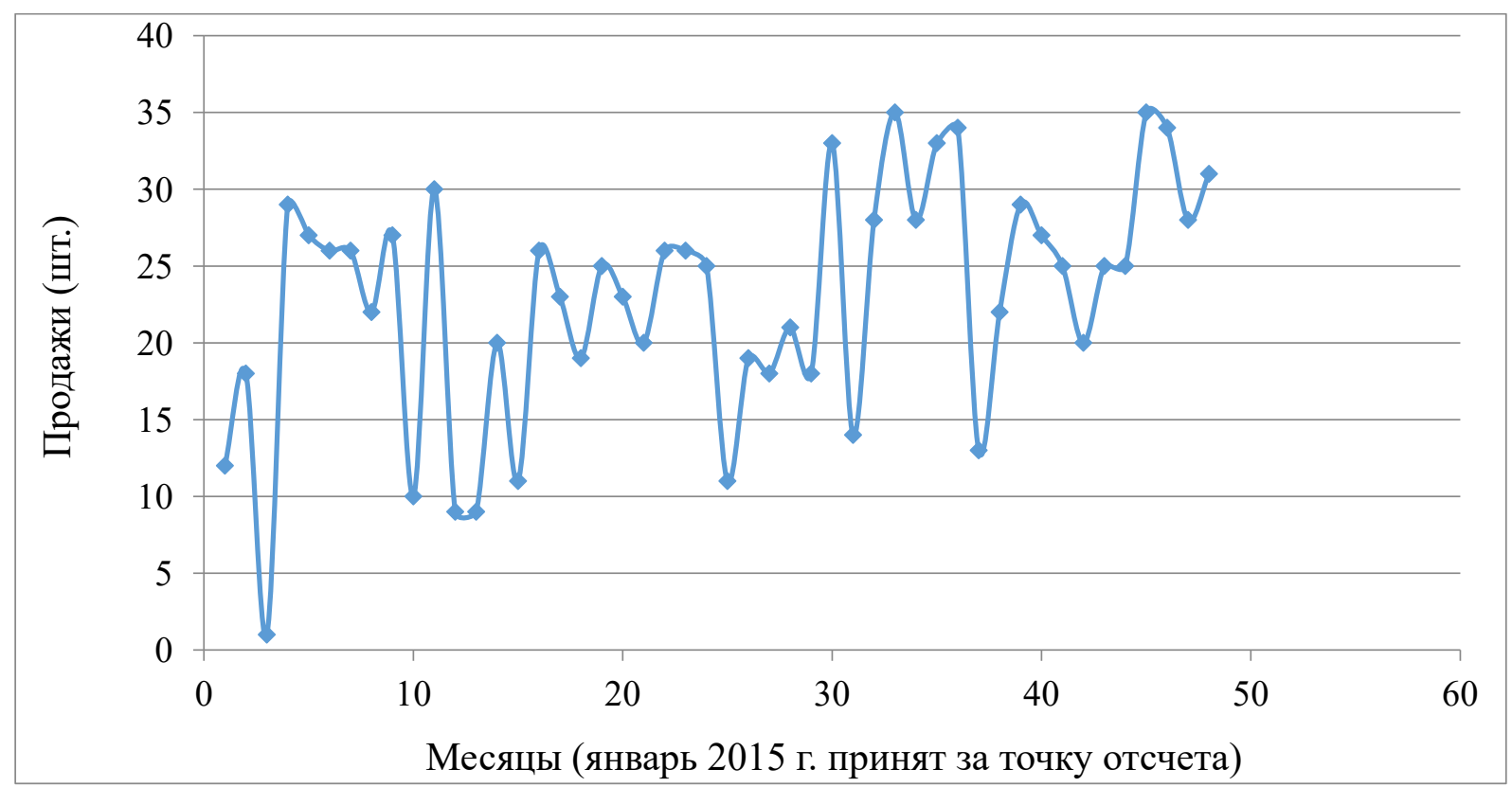

Рисунок 11. Динамика выручки за 2015-2018 гг. предприятия «Концепт Кар»

Визуализация исходных данных позволяет предположить наличие сезонных колебаний в динамике этого показателя с периодичностью 12 месяцев. Также в данном ряду динамики присутствует тренд: с течением времени показатель объема продаж растет. Кроме 
того, визуализация данных позволяет предположить мультипликативную модель ряда динамики. Для более точного описания сезонности периодичность колебаний определим с помощью коэффициентов автокорреляции. Расчеты проводятся в специально сформированной таблице, в которой показаны текущие уровни и уровни с лагом (сдвигом). В результате расчетов получили следующие коэффициенты автокорреляции: $r 1=0,14 ; r 2=0,26 ; r 3=0,16 ; \ldots r 12=0,51$; $r 13=0,38$. Коэффициент автокорреляции двенадцатого порядка оказался самым высоким. Значит, в исследуемом ряду наблюдаются сезонные колебания с периодичностью в 12 месяцев, то есть годовой цикл. После проведения сглаживания ряда динамики методом скользящей средней рассчитывалась сезонная компонента. Представим сезонную волну на рисунке 12.

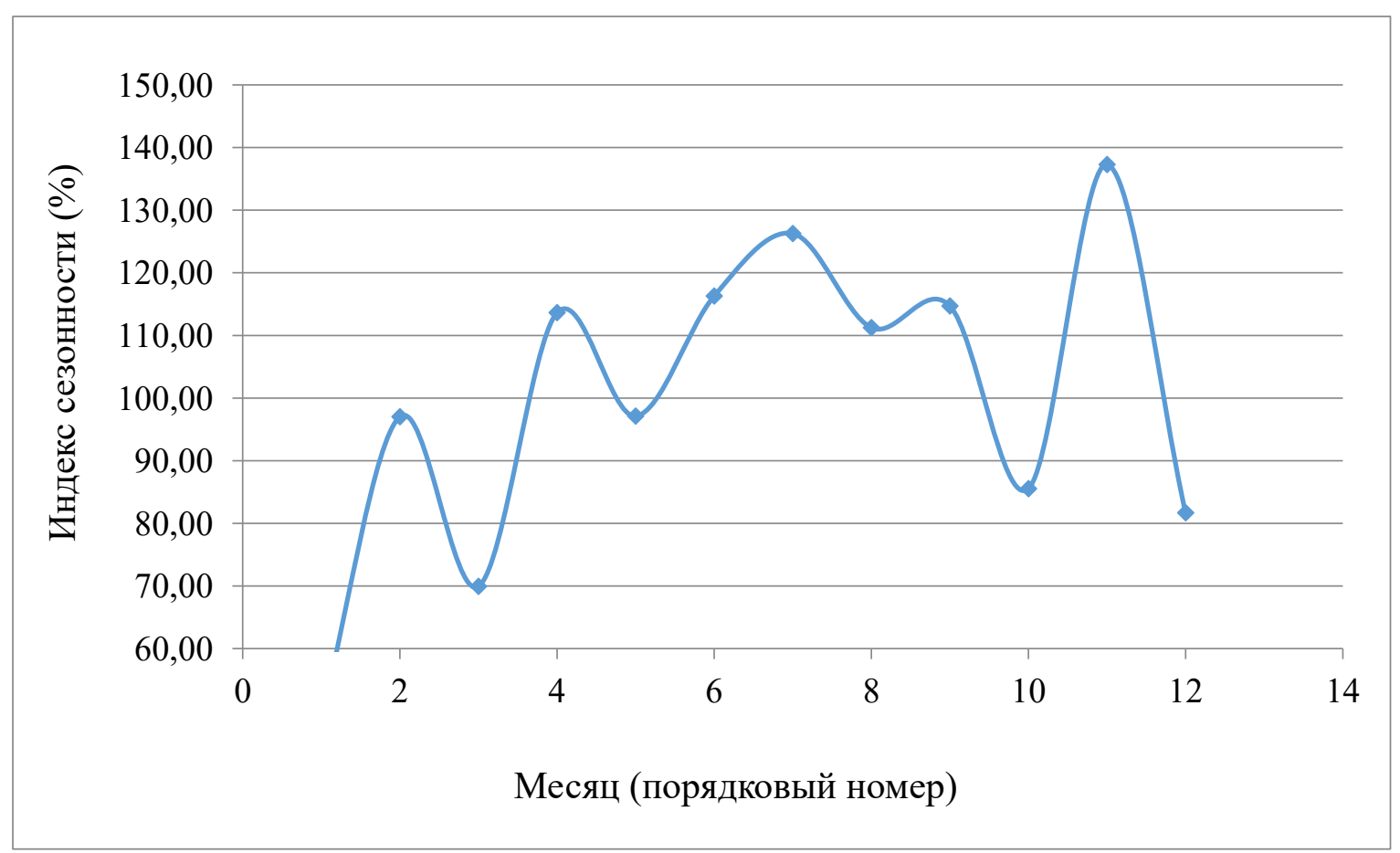

Рисунок 12. Сезонная волна в динамике выручки компании «Концепт Кар»

Как следует из представленных данных, объем продаж компании в течение четырех исследуемых лет подчинялся волновому характеру динамики. Пиковых значений у данного показателя не- 
сколько - в апреле, июле и ноябре. Далее, зная информацию относительно сезонности и сезонных компонент, можно уже проводить корреляционный анализ взаимосвязи уровня эмоционального интеллекта и объема продаж предприятия. Представим данные на рисунке 13 ниже.

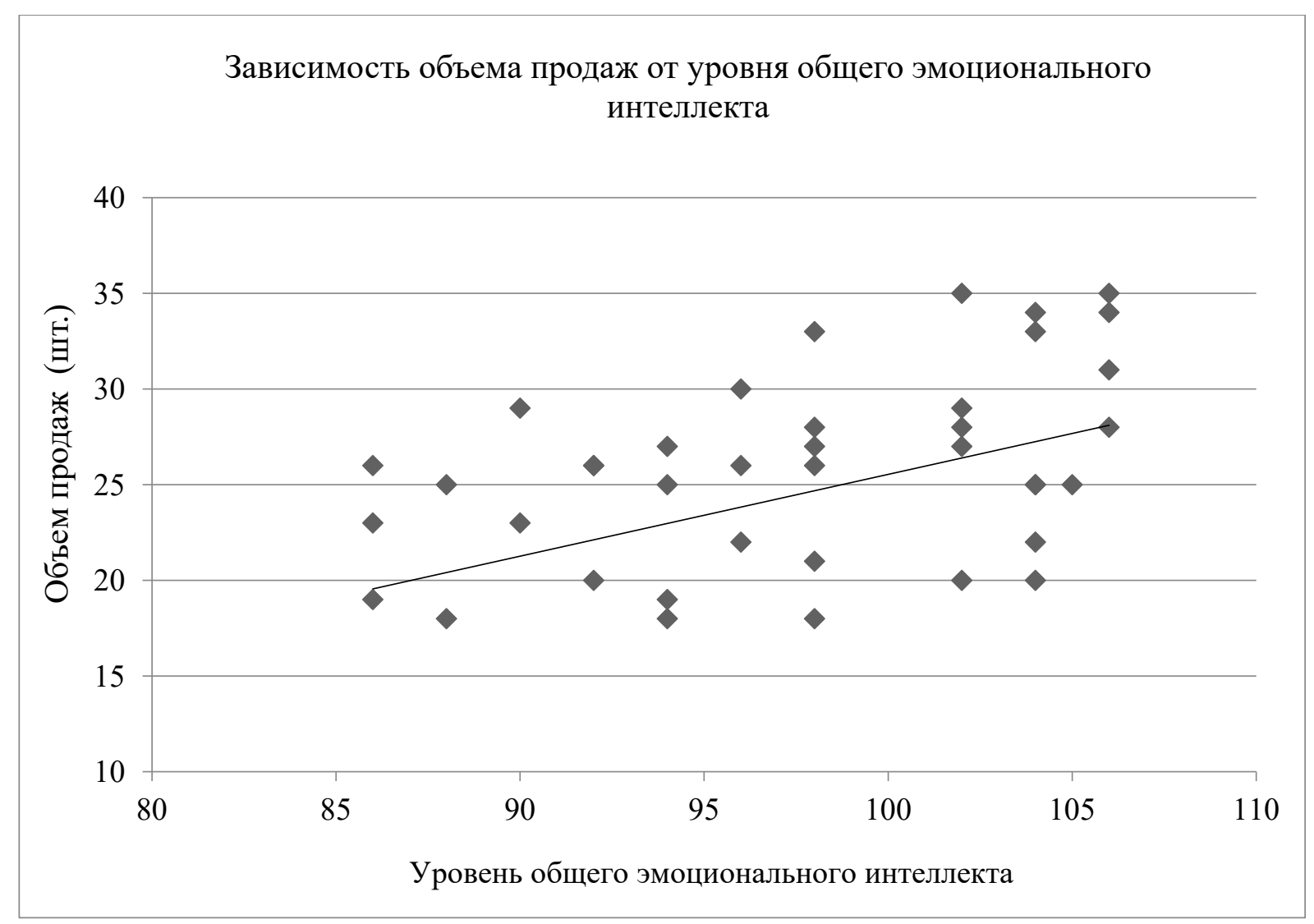

Рисунок 13. Зависимость объема продаж от уровня общего эмоционального интеллекта

Визуально можно сделать вывод о том, что связь, хоть и слабая, но все же присутствует. В результате корреляционного анализа были получены следующие данные: корреляция Пирсона - 0,39, коэффи-

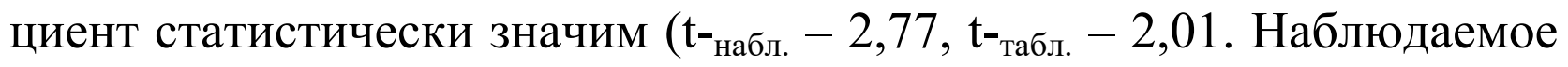
значение превышает табличное с вероятностью ошибки $<5 \%$ ). Можно сделать вывод о том, что взаимосвязь показателей статистически значима, и подтвердить гипотезу о том, что с повышением уровня общего эмоционального интеллекта увеличивается и объем 
продаж. Коэффициент детерминации 0,13\%, и он статистически значим. Это говорит о том, что объем продаж можно на 13 \% объяснить уровнем общего эмоционального интеллекта по отделу в целом. Связь в данном случае слабая, тем не менее с возросшим уровнем конкуренции необходимо учитывать любую возможность повышения достижения стратегических результатов предприятия в долгосрочной перспективе.

Для отдела продаж важно формировать состав не только с учетом опыта сотрудников в сфере продаж, но и с учетом уровня эмоционального интеллекта каждого. Далее рассмотрим, как уровень эмоционального интеллекта отдела по продажам легковых автомобилей премиум-класса влияет на долю рынка, которую занимает предприятие. Оценка будет дата на примере одного предприятия.

Оценка влияния уровня общего эмоционального интеллекта отдела продаж на долю рынка. Оценим, как с изменением уровня эмоционального интеллекта отдела меняется доля рынка предприятия. В городе Екатеринбурге есть два дилерских центра исследуемого бренда, следовательно, зная внутренние данные по продажам каждого из них можно посчитать долю рынка, которую занимает предприятие. Минимальное значение уровня общего эмоционального интеллекта в выборке - 86 пунктов, максимальное - 106 пунктов. Минимальное значение доли рынка - 44,0 \%, максимальное 51,9 \%. Визуально такая зависимость представлена на рисунке 14. Сезонность по результатам анализа автокорреляции отсутствует. 


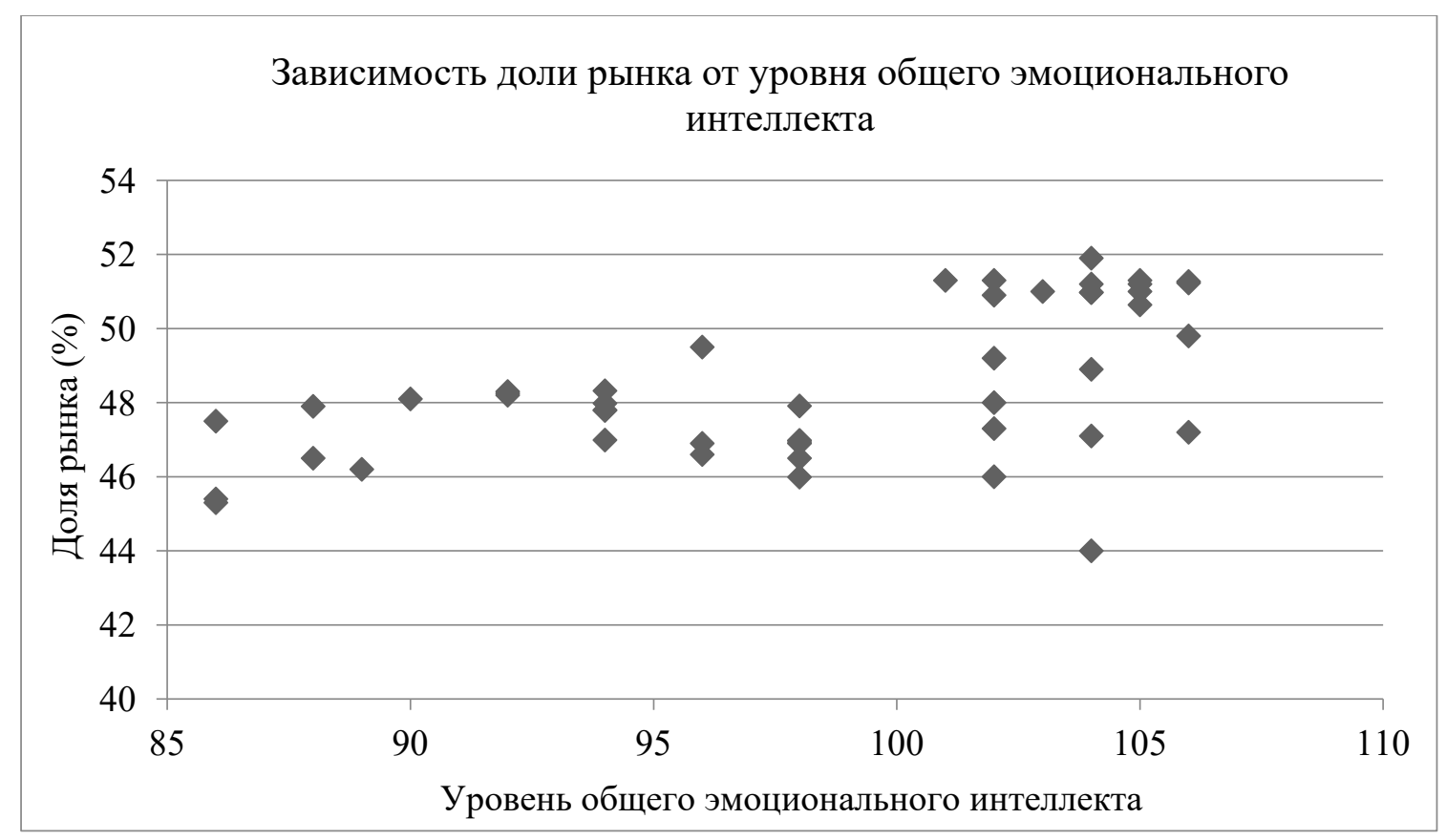

Рисунок 14. Зависимость доли рынка от уровня общего эмоционального интеллекта

Выбросы были устранены минимально, связь на графике прослеживается. В результате корреляционного анализа были получены следующие данные: корреляция Пирсона - 0,56, коэффициент статистически значим ( $\mathrm{t}_{\text {набл. }}-4,74, \mathrm{t}_{\text {табл. }}-2,01$. Наблюдаемое значение превышает табличное с вероятностью ошибки $<5 \%$ ). Можно сделать вывод о том, что взаимосвязь показателей статистически значима, и подтвердить гипотезу о том, что с повышением уровня общего эмоционального интеллекта увеличивается и доля рынка предприятия. Значение коэффициента детерминации по результатам регрессионного анализа - 0,32, и он статистически значим. Таким образом, изменение в проценте доли рынка предприятия на 32 \% объясняется уровнем эмоционального интеллекта в отделе продаж.

Оценка влияния уровня общего эмоччионального интеллекта отдела на прибыль предприятия от основного вида деятельности. Оценим взаимосвязь данных показателей на графике. Минимальное значение уровня общего эмоционального интеллекта в выборке - 86 пунктов, максимальное - 106 пунктов. Минимальное зна- 
чение прибыли - 1435 тыс. руб., максимальное - 2342 тыс. руб. Показатели прибыли также имеют сезонность 12 месяцев и линию тренда. Представленная ниже на рисунке 15 зависимость прибыли от продаж от уровня общего эмоционального интеллекта уже очищена от влияния сезонности.

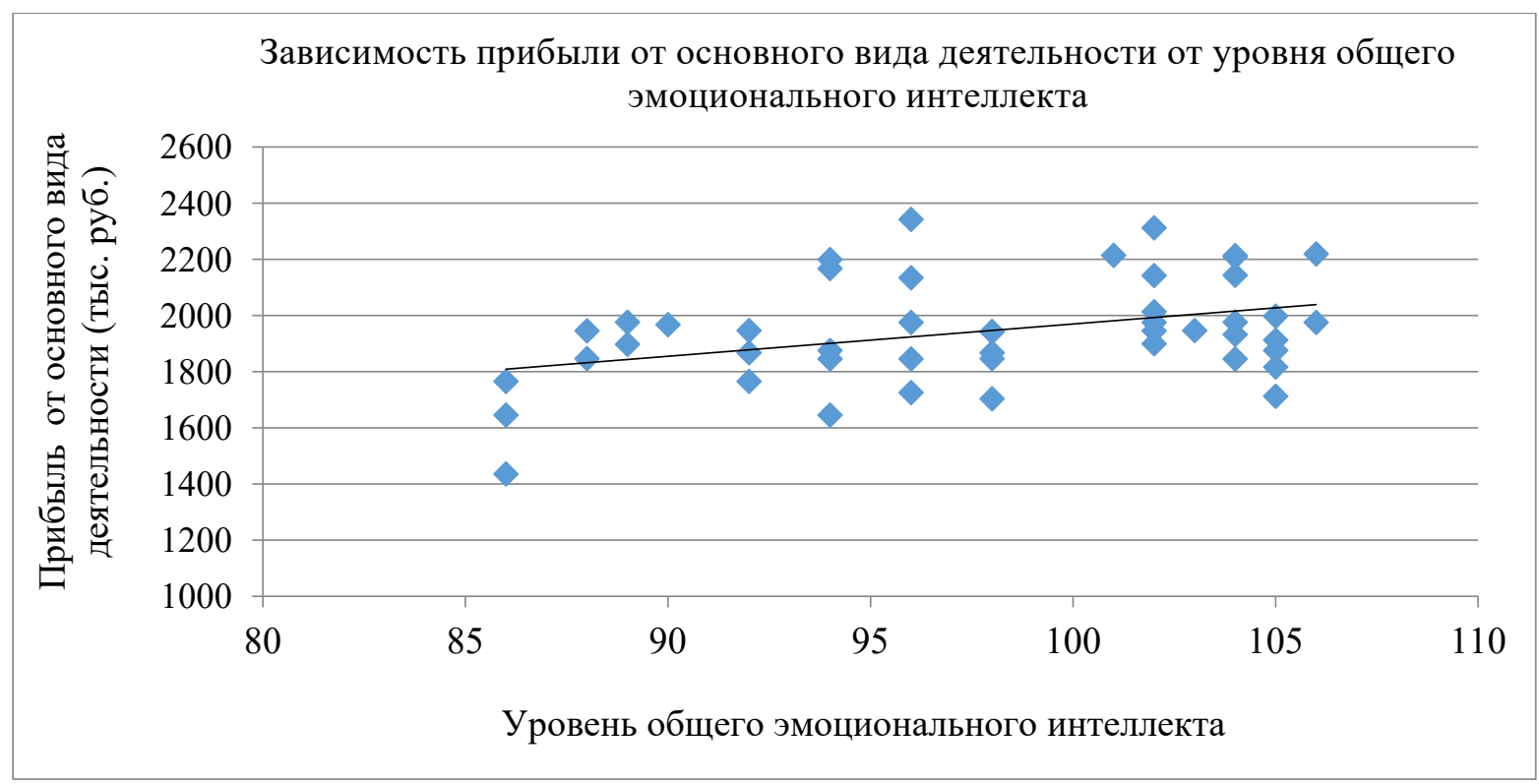

Рисунок 15. Зависимость прибыли от основного вида деятельности от уровня общего эмоционального интеллекта

Выбросы были устранены минимально, связь на графике прослеживается. Был проведен двумерный анализ количественных признаков. В результате корреляционного анализа были получены следующие данные: корреляция Пирсона - 0,46, коэффициент статистически значим ( $\mathrm{t}_{\text {набл. }}-3,55, \mathrm{t}_{\text {-табл. }}-2,01$. Наблюдаемое значение превышает табличное с вероятностью ошибки $<5 \%$ ). Таким образом, взаимосвязь показателей статистически значима, и подтвердить гипотезу о том, что с повышением уровня общего эмоционального интеллекта увеличивается и прибыль предприятия от основного вида деятельности. Значение коэффициента детерминации - 0,20, и он статистически значим. Таким образом, изменение в прибыли предприятия от основного вида деятельности на 20 \% объясняется уровнем общего эмоционального интеллекта сотрудников в отделе продаж. 
Взаимосвязь данного показателя необходимо считать в комплексе с выручкой предприятия от продаж автомобилей и рентабельностью. Сам показатель прибыли пока ни о чем не говорит. Потому что прибыль формируется, как уже было сказано, под воздействием разных внешних и внутренних факторов, потому что отпускные цены на продукцию непостоянны и предприятие само формирует ценовую политику, от чего и зависит в итоге прибыль.

Оценка влияния уровня общего эмоционального интеллекта отдела на выручку предприятия от основного вида деятельности. Оценим взаимосвязь данных показателей. Минимальное значение уровня общего эмоционального интеллекта в выборке - 86 пунктов, максимальное - 106 пунктов. Минимальное значение выручки 164253 тыс. руб., максимальное - 243561 тыс. руб. Визуально такая зависимость представлена на графике. Выручка предприятия также находится под влиянием сезонности и тренда к увеличению к концу года. Сезонность на предприятии - 12 месяцев. Представленные ниже на рисунке 16 данные уже очищены от сезонной компоненты и скорректированы в соответствии с индексами сезонности.

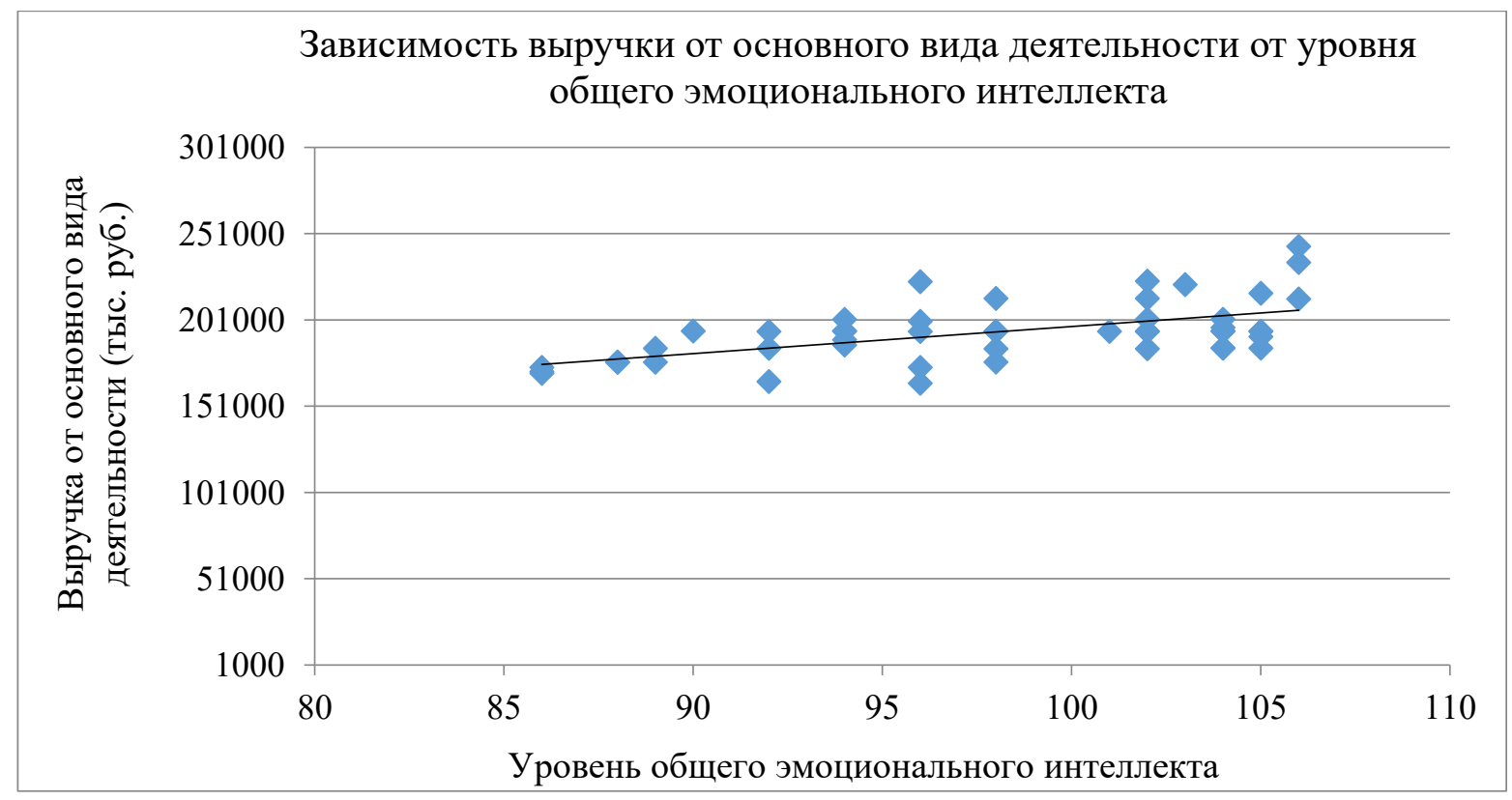

Рисунок 16. Зависимость выручки от основного вида деятельности от уровня общего эмоционального интеллекта 
Выбросы были устранены минимально, связь на графике прослеживается. Был проведен двумерный анализ количественных признаков. В результате корреляционного анализа были получены следующие данные: корреляция Пирсона - 0,57, коэффициент статистически значим ( $\mathrm{t}_{\text {набл. }}-4,76, \mathrm{t}_{\text {табл. }}-2,01$. Наблюдаемое значение превышает табличное с вероятностью ошибки $<5 \%$ ). Следовательно, можно сделать вывод о том, что взаимосвязь показателей статистически значима, и подтвердить гипотезу о том, что с повышением уровня общего эмоционального интеллекта увеличивается и выручка предприятия от основного вида деятельности. Значение коэффициента детерминации, которое было получено в ходе проведения регрессионного анализа, составило 0,30 , и оно статистически значимо. Таким образом, изменение выручки предприятия от основного вида деятельности на 30 \% объясняется уровнем общего эмоционального интеллекта в отделе продаж. Взаимосвязь выручки с уровнем общего эмоционального интеллекта намного сильнее, чем с прибылью. Это можно объяснить тем, что, во-первых, при высоком уровне эмоционального интеллекта у сотрудников отдела продаж замечается и рост объема продаж, что в свою очередь и определяет объем выручки предприятия, а прибыль зависит уже от размера отпускной цены на продукцию, которая индивидуально формируется для каждого уже без участия сотрудника отдела продаж в случае с конкретным предприятием. В случае если менеджер отдела продаж наделен полномочиями участвовать в процессе ценообразования, то в таком случае коэффициент детерминации может быть существенно выше, чем в данном конкретном примере.

Оценка влияния уровня общего эмоционального интеллекта отдела на рентабельность предприятия от продаж. Оценим взаимосвязь данных показателей. Сезонность при анализе коэффициентов автокорреляции отсутствует. Минимальное значение уровня общего эмоционального интеллекта в выборке - 86 пунктов, максимальное - 106 пунктов. Минимальное значение рентабельности - 
0,7 \%, максимальное - 1,2\%. Визуально такая зависимость представлена на рисунке 17.

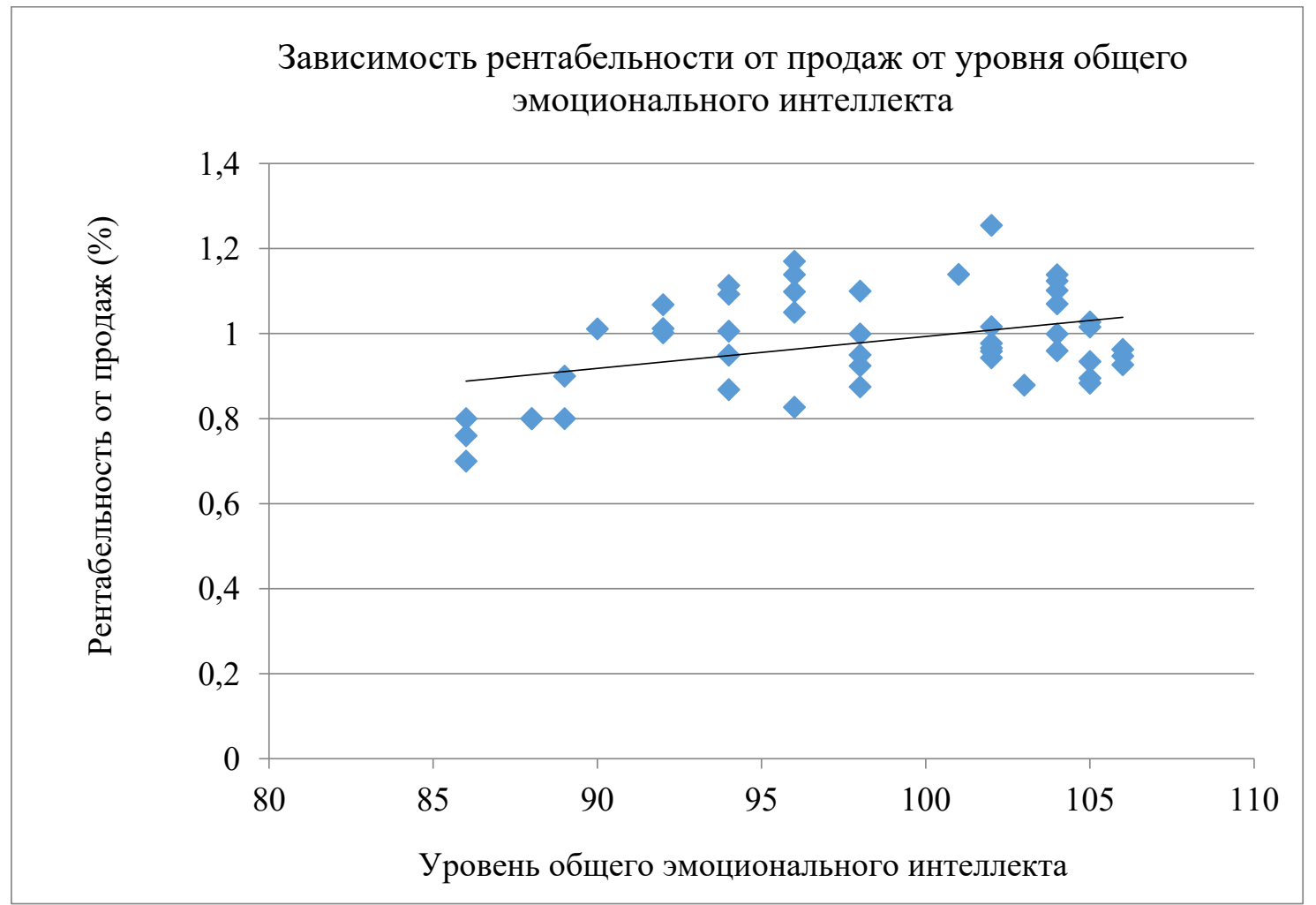

Рисунок 17. Зависимость рентабельности от продаж от уровня общего эмоционального интеллекта

Выбросы были устранены минимально, связь на графике прослеживается. В результате корреляционного анализа были получены следующие данные: корреляция Пирсона - 0,39, коэффициент статистически значим ( $\mathrm{t}_{\text {набл. }}-2,96, \mathrm{t}_{\text {табл. }}-2,01$. Наблюдаемое значение превышает табличное с вероятностью ошибки $<5 \%$ ). Взаимосвязь показателей статистически значима, и можно подтвердить гипотезу о том, что с повышением уровня общего эмоционального интеллекта увеличивается и рентабельность предприятия от продаж. Значение коэффициента детерминации - 0,11 , и он статистически значим. Таким образом, изменение рентабельности предприятия от продаж на $11 \%$ объясняется уровнем общего эмоционального интеллекта в отделе сбыта. 
После проведения исследования можно сделать следующие выводы: во-первых, уровень эмоционального интеллекта сотрудников отдела продаж оказывает влияние на показатели экономических результатов деятельности предприятия. Выдвигаемые гипотезы подтвердились. Во-вторых, основное влияние уровень эмоционального интеллекта оказывает на процент выполнения ежемесячного плана продаж, на выручку и долю рынка предприятия. Представим в таблице 15 полученные результаты исследования.

Таблица 15.

Взаимосвязь уровня эмоционального интеллекта сотрудников отдела сбыта с показателями хозяйственной деятельности предприятия

\begin{tabular}{|c|c|c|c|}
\hline \multirow[b]{2}{*}{ Гипотеза } & \multicolumn{3}{|c|}{ Показатели } \\
\hline & $\begin{array}{c}\text { Уровень } \\
\text { значимости } \\
\text { коэффици- } \\
\text { ента детер- } \\
\text { минации }\end{array}$ & $\begin{array}{l}\text { Коэффи- } \\
\text { циент де- } \\
\text { термина- } \\
\text { ции (\%) }\end{array}$ & $\begin{array}{c}\mathrm{t}-{ }_{\text {набл }}- \\
\mathrm{t}-{ }_{\text {табл }}\end{array}$ \\
\hline $\begin{array}{l}\text { Влияние уровня эмоционального } \\
\text { интеллекта сотрудников на коэф- } \\
\text { фициент выполнения ежемесячного } \\
\text { плана продаж }\end{array}$ & 0,00 & 32,00 & $\begin{array}{c}4,10> \\
2,01\end{array}$ \\
\hline $\begin{array}{l}\text { Влияние уровня эмоционального } \\
\text { интеллекта сотрудников на объем } \\
\text { продаж }\end{array}$ & 0,01 & 13,00 & $\begin{array}{c}2,77> \\
2,01\end{array}$ \\
\hline $\begin{array}{l}\text { Влияние уровня эмоционального } \\
\text { интеллекта сотрудников на долю } \\
\text { рынка предприятия }\end{array}$ & 0,00 & 32,00 & $\begin{array}{c}4,74> \\
2,01\end{array}$ \\
\hline $\begin{array}{l}\text { Влияние уровня эмоционального } \\
\text { интеллекта сотрудников на прибыль } \\
\text { предприятия }\end{array}$ & 0,00 & 20,00 & $\begin{array}{c}3,55> \\
2,01\end{array}$ \\
\hline
\end{tabular}


Окончание Таблицы 15

\begin{tabular}{|l|c|c|c|}
\hline $\begin{array}{l}\text { Влияние уровня эмоционального } \\
\text { интеллекта сотрудников на выручку } \\
\text { предприятия }\end{array}$ & 0,00 & 30,00 & $\begin{array}{c}4,76> \\
2,01\end{array}$ \\
\hline $\begin{array}{l}\text { Влияние уровня эмоционального } \\
\text { интеллекта сотрудников на рента- } \\
\text { бельность от продаж }\end{array}$ & 0,02 & 11,00 & $\begin{array}{c}2,96> \\
2,01\end{array}$ \\
\hline
\end{tabular}

Из таблицы выше можно заметить, что эмоциональный интеллект не оказывает сильного влияния на рост объема продаж. В данном случае это объясняется, во-первых, тем, что с начала 2015 года резко вырос курс доллара к рублю, что положительно сказалось на выручке предприятия, но отрицательно сказалось на росте объема продаж в рамках исследуемого периода. При увеличении уровня эмоционального интеллекта сотрудников в отделе речь шла не о росте продаж в штуках, а об удержании текущего уровня продаж и не допустить большого падения доли предприятия на рынке. Данная задача была успешно выполнена предприятием, что позволяет судить о том, что уровень эмоционального интеллекта сотрудников на предприятии влияет не только на выполнение стратегических задач в долгосрочной перспективе, но и на устойчивость предприятия во время стагнации рынка и нестабильной экономической ситуации, особенно в области продаж автомобилей высокой ценовой категории. 


\section{3. РАЗРАБОТКА ИНСТРУМЕНТАРИЯ ПО ОЦЕНКЕ И УПРАВЛЕНИЮ ДЕЯТЕЛЬНОСТЬЮ ПРЕДПРИЯТИЯ С УЧЕТОМ ВЛИЯНИЯ ЭМОЦИОНАЛЬНОГО ИНТЕЛЛЕКТА}

\section{1. Место эмоционального интеллекта в структуре сбалансированной системы показателей}

В эпоху перемен, неопределенности, высокой степени риска вопрос выживаемости и стабильность работы предприятия актуален как никогда. На рубеже нового десятилетия экономике и обществу пришлось столкнуться с новыми вызовами, которые пошатнули старые представления о многих законах и механизмах, которые достаточно долго объясняли функционирование многих систем. Коренные изменения в мировоззрении и не только, которые произошли в конце прошлого столетия, подарили стране новое поколение учеников, студентов, рабочих, лидеров и предпринимателей, которые меняют кардинальным образом устоявшиеся нормы и правила почти во всех структурах жизни общества. Всеобщая цифровизация населения привела к доступности информации и, вместе с тем, создала определенные сложности в вопросах ее верификации, подлинности и достоверности. Тем не менее цифровизация подтолкнула общество к упрощению взаимодействия и десятикратному ускорению в коммуникации и получению информации. Цифровизация сделала возможным выход предприятий в интернет и увеличение объема продаж и прибыли. Скорость коммуникации возросла, чего не скажешь о ее качестве. Вместе с тем рос и менялся потребитель, который уже воспитывался не в эпоху дефицита, и, соответственно, поменялись и требования такого поколения к качеству товаров и услуг. Современное общество, поколение $\mathrm{Y}$, даже уже поколение $\mathrm{Z}$ вступило в эпоху активной трансформации мира, общества вокруг себя. Общество сейчас пытается решить комплекс проблем: как развивать, как обу- 
чать и как управлять вне зависимости от сферы, к которой эти вопросы могут быть применимы.

Раньше рынок и продажа товаров и услуг были устроены по принципу «человек - продукт» [70]. В 1991 году объем рынка рос по экспоненте, появлялись новые товары, компании и бесчисленное количество возможностей, которые заполонили все постсоветское пространство [73]. Потребителю не приходилось долго выбирать, а предприятиям - продавать в прямом смысле этого слова, ведь в то время продажа воспринималась не как процесс взаимодействия, а как совершение определенной операции: оформление документов, процесс трансформации денежных эквивалентов в товар и наоборот. В процессе становления уже российской экономики, формируется новый принцип взаимодействия на рынке: «человек - компания» [71]. После периода профицита потребитель уже научился разбираться во всем многообразии продукта, в то время как более успешные участники рынка - предприятия - определили свои позиции и установили зоны влияния, которые в некоторых сферах наблюдаются до сих пор. Потребителю стало комфортнее выбирать не только товар, но и компанию, с которой ему нравится сотрудничать, которая предлагает определенные преференции для своих покупателей. Конкуренция на рынке стала усиливаться, начинают появляться различные бизнестренеры, программы по развитию персонала, увеличению эффективности, и частные предприятия погружаются в исследование новейших в России, но не на Западе, методик управления всеми процессами на предприятии. Внедряются активно в наиболее продвинутые и технологичные компании CRM-системы, эффективность измеряется чуть ли не на каждом шагу. Процесс продажи переходит от действия к алгоритму - то есть для успешной продажи необходимо соблюдение определенной последовательности действий, компании начинают более подробно изучать методики продажи и основные концепции, для обретения конкурентного преимущества. При этом все показатели эффективности обезличены и несут в себе исключительно 
количественную обработку данных без включения психоэмоциональной компоненты в процесс их анализа.

В последнее время «человек - человек» [72]. Многие продукты, товары приобретаются по рекомендации. Люди покупают медицинские услуги у врачей по рекомендации, стараются работать с риелторами по рекомендации, нанимать бригаду строителей по рекомендации, в общем, искать знакомых и надежных лиц почти в каждом случае, когда речь идет о затрате значительной суммы денег на приобретение благ. Уровень значимости личной коммуникации неуклонно растет. Сколько раз мы совершали покупки порой из-за устоявшихся отношений или из-за того, что человек «просто понравился».

Экономическое поведение потребителя в условиях современной рыночной экономики подразделяют на рациональное и иррациональное. Исследованием этих процессов занимается поведенческая экономика, которая изучает, что же может являться условным катализатором совершения экономических действий, которые могут идти вразрез с общепринятыми экономическими законами [70]. Процесс продажи товара на рынке тоже изменился. Теперь определенной последовательности действий недостаточно, различные внутрикорпоративные стандарты продаж есть уже почти у каждой компании. Потребитель хорошо ориентируется в ценах, благодаря интернету, перед тем как совершить покупку, он ознакомится с отзывами, изучает характеристику и так далее. И зачастую потребитель уже подходит к моменту покупки, имея определенный комплекс знаний, представлений и предубеждений.

Продажа уже представляет собой мульти вариативный процесс, который затрагивает преодоление не только большого количества возражений, но и тенденцию к выстраиванию долгосрочных отношений, основанных на доверии и взаимопонимании. Предложены следующие виды потребителей в России, на основании статей на английском языке. 2018 год был провозглашен годом Н2Н [72]. 
Таблица 16 ниже была составлена и доработана на основании источников на иностранном языке [70, 72, 73, 74], которые за последние 2 года обрели большую популярность на западе. Н2Н был предложен в 2014 году Брайаном Крамером и активно развивается в других странах.

Таблица 16.

Виды взаимодействия потребителей и продукта

\begin{tabular}{|c|c|c|}
\hline Виды взаимодействия & $\begin{array}{c}\text { Степень влияния } \\
\text { эмоционального } \\
\text { интеллекта в виде } \\
\text { взаимодействия }\end{array}$ & $\begin{array}{c}\text { Характеристика } \\
\text { процесса продажи } \\
\text { товара }\end{array}$ \\
\hline Человек - продукт & низкая & Продажа как действие \\
\hline Человек - компания & средняя & Продажа как алгоритм \\
\hline Человек - человек & высокая & Продажа как процесс \\
\hline
\end{tabular}

Анализ базовых экономических показателей, которые характеризуют успешность деятельности предприятия, уже невозможен без включения личностной составляющей. Речь идет не об анализе финансовой устойчивости предприятия или управления запасами на предприятии. Размер прибыли компании зависит от умения строить конструктивную коммуникацию с другими людьми в процессе реализации товара предприятия и учитывает некий уровень эффективности общения с людьми. Таким мерилом сегодня является уровень эмоционального интеллекта. Ведь именно этот показатель позволяет судить о степени присутствия в каждом человеке неких индивидуальных характеристик, которые обуславливают успешность выстраивания отношений с другими участниками взаимодействия. Прежде чем встраивать компоненту эмоционального интеллекта в систему оценки результатов экономической деятельности предприятия и предлагать алгоритм, следует задать некие базовые условия, 
которые должны выполняться для обеспечения жизнеспособности предлагаемого алгоритма. Во-первых, принимается утверждение, что уровень эмоционального интеллекта сотрудника оказывает влияние на его продуктивность и, как следствие на результат работы предприятия, только в том случае, где присутствует сам факт такого взаимодействия. Например, продавец-консультант в гипермаркете бытовой электроники и продавец в продуктовом магазине относятся к совершенно разным категориям сотрудников сбытового отдела с отличным набором функций, задач и мерой общения с потребителем. Во-вторых, на предприятии уже внедрена, пусть и самая базовая система контроля качества и оценки эффективности линейного персонала (ERP). На предприятии настроен подсчет базовых значений для анализа эффективности работы отдела сбыта, как то: телефонные обращения, личные обращения, e-mail-обращения и другие релевантные для предприятия точки для оценки продуктивности работы линейного персонала сбытового отдела.

Определение вида предприятия. Универсального алгоритма не существует ни в одной сфере, потому что специфики внедрения новшеств и актуальные профессиональные и рыночные условия на предприятиях разные. Первый шаг для определения места имплементации компоненты эмоционального интеллекта в существующую структуру оценки экономических результатов деятельности предприятия - определение вида малого предприятия в сфере розничной и оптовой торговли. Сущностно-экономический подход по отраслевой принадлежности, согласно которому в структуре типологии малых предприятий выделяют сферу оптовой и розничной торговли, можно развить и предложить следующие виды малых предприятий по соотношению стоимости товаров и длины сделки, которая графически представлена на рисунке 18. 


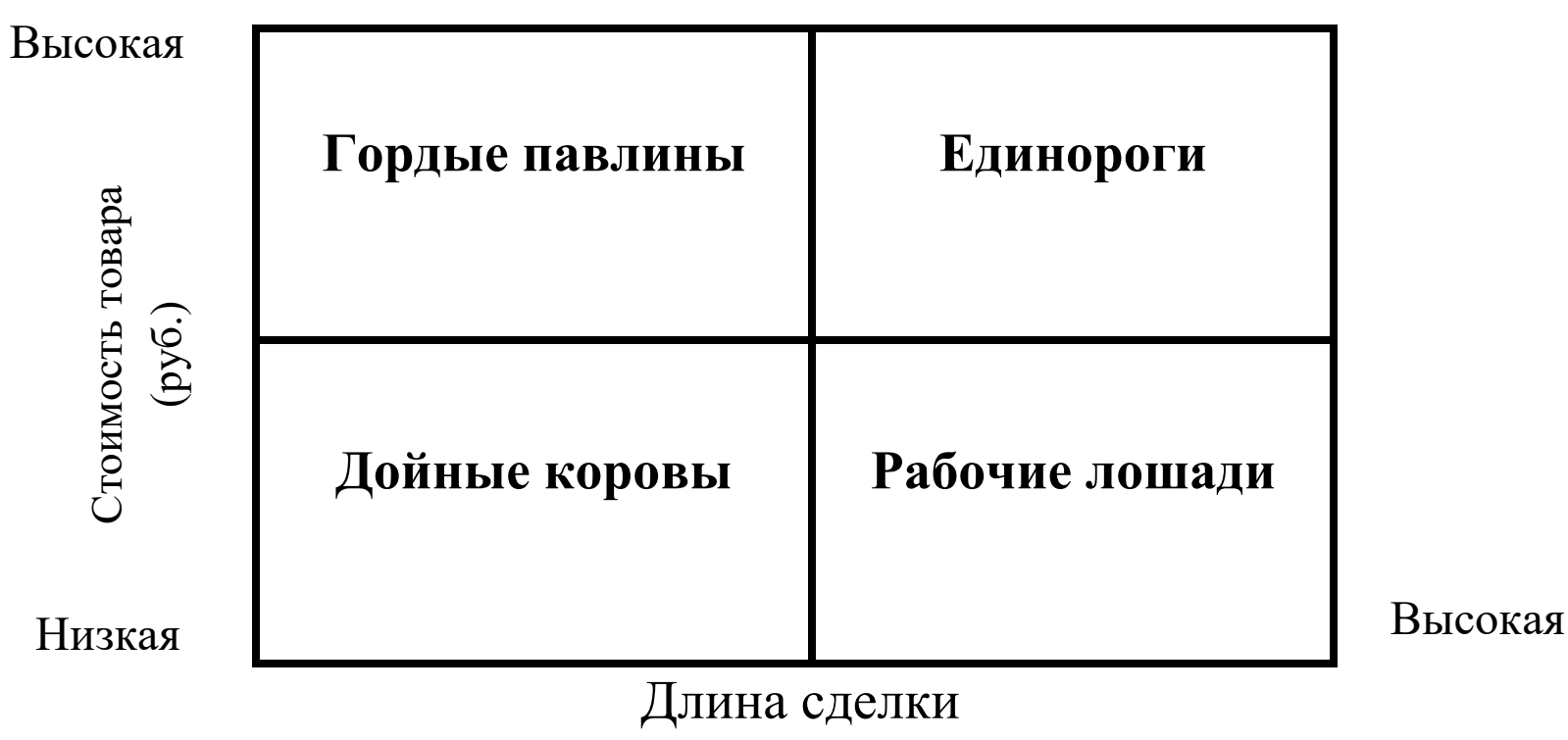

Рисунок 18. Виды малых предприятий в сфере розничной торговли

K первому виду предприятий относятся малые предприятия в сфере розничной торговли, которые специализируются на продажах товаров в основном регулярного спроса и низкой и средней ценовой категории. Длина сделки в этом сегменте очень короткая: от нескольких минут до нескольких часов. При этом определенная степень участия специалиста по продажам в сделке присутствует, и точка приложения навыков, которые предполагает эмоциональный интеллект, имеется. Такими предприятиями могут быть: розничные магазины по продаже монопродукта, например винотеки, ювелирные магазины, магазины по продаже бытовой техники масс-сегмента, крупные магазины парфюмерии и косметики, в которых представлены в основном товары среднего ценового сегмента. Поток клиентов очень большой, поскольку доля потребителей в России класса ниже среднего велика и растет с 2014 года [75].

Ко второму виду предприятий относятся малые предприятия в сфере розничной торговли, которые специализируются на продаже товаров премиум- и люкс-сегмента. Это товары высокой ценовой категории, при этом длина сделки тоже достаточно быстрая. Роль специалиста по продажам в этом сегменте увеличивается, как и требо- 
вания к его навыкам, умениям и качеству работы с потенциальным потребителем. Такими предприятиями могут быть магазины по продаже эксклюзивных брендов одежды, оптики, часов, предметов антиквариата, дорогих марок парфюмерии и косметики класса люкс. Поток клиентов небольшой, ведь ядро среднего класса в России составляет всего $7 \%$, а общая численность потребителей среднего класса в России - около 38 \%, причем около 19 \% относятся к периферии [там же].

$K$ третьему виду предприятий относятся малые предприятия в сфере розничной торговли, которые предлагают товары средней ценовой категории, но длина сделки при этом достаточно долгая. Такими товарами могут быть автомобили марок масс-бренда. Роль специалиста по продажам достаточно высока, потому что в этой категории необходимо в течение долгого периода поддерживать контакт с клиентом и внимательно подходить к его запросам. Поток клиентов средний. В чем-то этот вид схож со вторым, но основное различие заключается в длине сделки. Стоимость товара в данном случае «низкая» условно.

K четвертому виду предприятий относятся малые предприятия в сфере розничной торговли, которые предлагают товары класса люкс и элит. Длина сделки длинная. Речь идет о продаже дорогих автомобилей, яхт, эксклюзивных изделий из редких пород камней и прочих товаров класса люкс. Поток клиентов в этом сегменте не такой большой и при этом качество обработки специалистом по продажам растет как никогда. Требования к таким специалистам очень высокие.

Роль специалиста по продажам в каждом из этих видов малых предприятий уникальная и различная, как и собственно точки, в которых эффективность работы менеджера может быть оцифрована и связана с эмоциональным интеллектом. Итак, первым шагом к внедрению психоэмоциональной компоненты оценки производительно- 
сти труда специалиста по продажам следует считать определение вида предприятия, потому что от вида предприятия зависит построение и наполнение системы сбалансированных показателей и определение места этой компоненты в структуре оценки эффективности специалиста сбытового отдела, которая влияет на экономические результаты деятельности предприятия. В работе уже было дано краткое описание определения системы сбалансированных показателей и обозначены цели, для которых такая система вводится на предприятиях. Сегодня это одна из самых широко используемых систем для оценки результатов работы отдела и предприятия в целом. В зависимости от вида предприятия можно определить состав ССП и выделить из состава ССП те показатели, на которые, уровень эмоционального интеллекта оказывает воздействие. Далее в работе будут предложены показатели, на которые влияет эмоциональный интеллект и которые рекомендуется включать в состав ССП.

Определение базового состава системь показателей для оченки результатов деятельности для разных видов малых предприятий сферы розничной торговли. Рассмотрим первый вид предприятия - «Дойные коровы». С учетом специфики ведения бизнеса выделим те показатели, на которые эмоциональный интеллект влияет в таблице 17. Определить такие показатели просто: во-первых, это коэффициент выполнения плана продаж. Он рассматривается для любого вида предприятия. Этот коэффициент включаем в состав ССП, потому что ранее было доказано эмпирическим путем, что эмоциональный интеллект влияет на выполнение плана продаж. Остальные показатели выбираются по принципу прямого участия специалиста по продажам в формировании результата такого показателя. 
Таблица 17.

Система сбалансированных показателей для сбытового отдела предприятия вида «Дойная корова»

\begin{tabular}{|l|l|}
\hline \multicolumn{1}{|c|}{ Показатель } & \multicolumn{1}{|c|}{ Методика расчета } \\
\hline Выручка (руб.) & $\begin{array}{l}\text { Разность стоимости реализован- } \\
\text { ного товара к себестоимости }\end{array}$ \\
\hline $\begin{array}{l}\text { Коэффициент выполнения плана } \\
\text { продаж (\%) }\end{array}$ & $\begin{array}{l}\text { Отношение факта продаж к пла- } \\
\text { ну продаж }\end{array}$ \\
\hline Объем выручки за транзакцию (руб.) & $\begin{array}{l}\text { Отношение выручки к количе- } \\
\text { ству транзакций }\end{array}$ \\
\hline Длина чека (шт.) & $\begin{array}{l}\text { Отношение количества покупок } \\
\text { к общему количеству чеков }\end{array}$ \\
\hline
\end{tabular}

В ССП для предприятия этого вида включены четыре показателя. Первый - коэффициент выполнения плана продаж. О его важности было сказано выше. Второй - выручка, он тоже базовый, поскольку это один из основных показателей результатов деятельности предприятия. Эмоциональный интеллект влияет косвенно - в зависимости от выполнения плана продаж меняется и выручка предприятия. Объем выручки за транзакцию служит для определения уровня качества работы с покупателем. Так, чтобы рассчитать значение этого показателя необходимо выручку поделить на количество транзакций. Это первый показатель, в котором можно уже выделить определенное влияние эмоционального интеллекта на результат предприятия. Так, повышение этого показателя может говорить о том, что специалист по продажам продает сопутствующие товары, активно продает товары более дорогой ценовой категории. Этот показатель можно считать как индивидуально по сотруднику, так и по отделу в целом. Так один 
сотрудник, например, может продавать на 5000 рублей, а второй - на 10000 рублей.

Следующий показатель, на показатель которого тоже может влиять эмоциональный интеллект - это длина чека. Длина чека вычисляется отношением общего количества покупок к количеству пробитых чеков. Речь идет о способности специалиста по продажам в процессе диалога с потребителем предлагать дополнительные товары, продавать товары со скидкой, считать количество проданных продуктов по специальной акции. Этот показатель может рассчитываться как по всему отделу в целом, так и по каждому сотруднику в отдельности.

В системе оценки результатов деятельности сбытового отдела предприятий вида «Дойная корова», место и влияние эмоционального интеллекта специалиста сбытового отдела ограничено четырьмя показателями - выручкой, коэффициентом выполнения плана продаж, объемом выручки за транзакцию и длинной чека. После измерения уровня эмоционального интеллекта сотрудника, выстраивать взаимосвязь и рассчитывать процент влияния уровня эмоционального интеллекта сотрудника на производительность труда и показатели эффективности работы предприятия необходимо на примере выявленных показателей.

Рассмотрим второй вид предприятия - «Гордые павлины». В отличие от «Дойных коров», объем клиентского трафика в этом случае намного меньше в виду специфики и эксклюзивности товара. Количество потенциальных покупателей тоже, следовательно, качество работы с такими клиентами должно быть выше в виду высокого уровня конкуренции. Как правило, объем SKU в таких компаниях намного меньше, чем в компаниях первого вида, расположение товарных позиций в торговом зале имеет значение и стандарты размещения с точки зрения потенциальной привлекательности для клиента и брэнд-буков, если предприятие является дилерским центром [76]. В та- 
ких компаниях невозможно поставить все 15 сумок на одну полку и в один ряд - это влияет на презентацию товара и привлекательность товара для потенциального потребителя [76]. Как правило, очень много клиентов проводят в таких магазинах намного больше времени, чем в первом случае. Специалист по продажам может установить более плотный личный контакт с целью уже не только единичной продажи, но и с целью привить потенциальному покупателю определенную лояльность к бренду, компании, таким образом, оказав влияние и на объем выручки предприятия. Рассмотрим предлагаемые показатели для ССП такого вида предприятия в таблице 18.

Таблица 18.

Система сбалансированных показателей для сбытового отдела предприятия вида «Гордый павлин»

\begin{tabular}{|l|l|}
\hline \multicolumn{1}{|c|}{ Показатель } & \multicolumn{1}{|c|}{ Методика расчета } \\
\hline $\begin{array}{l}\text { Коэффициент выполнения плана } \\
\text { продаж (\%) }\end{array}$ & $\begin{array}{l}\text { Отношение факта продаж } \\
\text { к плану продаж }\end{array}$ \\
\hline Выручка (руб.) & $\begin{array}{l}\text { Разность стоимости реализованного } \\
\text { товара к себестоимости }\end{array}$ \\
\hline $\begin{array}{l}\text { Объем выручки за транзакцию } \\
\text { руб.) }\end{array}$ & $\begin{array}{l}\text { Отношение выручки к количеству } \\
\text { транзакций }\end{array}$ \\
\hline Длина чека (шт.) & $\begin{array}{l}\text { Отношение количества покупок } \\
\text { к общему количеству чеков }\end{array}$ \\
\hline Конверсия по визитам (\%) & $\begin{array}{l}\text { Отношение количества продаж } \\
\text { к количеству визитов }\end{array}$ \\
\hline
\end{tabular}

Предлагаемыми показателями для ССП по данному виду предприятия неизменными компонентами, которые уже были рассмотрены, в первом случае являются выполнение плана продаж, выручка, объем выручки за транзакцию и длина чека. Также до- 
бавлен новый компонент - показатель конверсии по визитам, который позволяет судить о качестве обработки сотрудником входящего трафика. Его не было в ССП на предприятиях первого вида, потому что трафик на таких предприятиях очень большой, невозможно при таком количестве трафика отследить, сколько людей пришло к конкретному сотруднику и ушло от него с покупкой. На предприятиях вида «Гордый павлин» трафик намного ниже, потому что количество потенциальных покупателей меньше, следовательно, появляется возможность сосчитать всех покупателей, с которыми работал выделенный специалист. Эмоциональный интеллект, как уже было установлено ранее, имеет непосредственное отношение к уровню этого показателя.

Можно сделать вывод, что для предприятий вида «Гордый павлин», место и влияние эмоционального интеллекта специалиста сбытового отдела ограничено уже пятью, а не четырьмя показателями - объемом выручки за транзакцию, длинной чека, показателем конверсии по визитам и выполнению плана продаж, а также выручкой. После измерения уровня эмоционального интеллекта сотрудника необходимо выстраивать взаимосвязь и рассчитывать процент влияния эмоционального интеллекта на производительность труда и, как следствие, на экономические результаты деятельности предприятия необходимо на примере предложенных пяти показателей.

Рассмотрим третий вид предприятия - «Рабочие лошади». В отличие от первых двух видов, это первый, в котором длина сделки может занимать гораздо большее время. Хотелось бы сразу сделать оговорку, что возможность приобрести, например, автомобиль за короткий срок, безусловно присутствует, но для этого необходимо соблюдение совокупности следующих компонент: наличие нужного товара, в определенном месте, по определенным критериям, в рамках установленного бюджета и без дополнитель- 
ных временных затрат на подготовку документов. Ведь когда речь идет о покупке автомобиля, в большинстве случаев потребитель может рассматривать и альтернативные источники финансирования покупки, что может повлиять на время, в течение которого сделка может быть заключена.

За этот период, от момента точки входа клиента в компанию до момента его выхода с удовлетворенной потребностью, специалист по продажам оказывает огромное влияние на большое число факторов, в том числе и рисков, которые могут появиться в процессе совершения сделки. Ни для кого не секрет, что даже при заключенном договоре, но без факта оплаты товара, при появлении наиболее выгодной альтернативы потенциальный потребитель склонен рассматривать и другие предложения от конкурентов. Это только один из примеров, в которых уровень мастерства специалиста по продажам может сыграть ключевую роль и привести в итоге либо к тому, что сделка будет завершена и предприятие получит прибыль, либо к тому, что потребитель может уйти к конкуренту.

Учитывая более длинный путь клиента от точки входа до совершения покупки, увеличивается и количество этапов, на которых можно будет оценить эффективность работы менеджера, как в количественном, так и в абсолютном выражении. Цена каждого клиента для этого вида предприятия очень высока не только с точки зрения конечного результата выручки, но и с точки зрения структуры затрат на привлечение этого клиента, и с точки зрения вероятности повторных покупок. Представим в таблице 19 предлагаемые показатели для ССП предприятий такого вида. 
Таблица 19.

Система сбалансированных показателей для сбытового отдела предприятия вида «Рабочая лошадь»

\begin{tabular}{|l|l|}
\hline \multicolumn{1}{|c|}{ Показатель } & \multicolumn{1}{|c|}{ Методика расчета } \\
\hline $\begin{array}{l}\text { Коэффициент выполнения } \\
\text { плана продаж (\%) }\end{array}$ & Отношение факта продаж к плану продаж \\
\hline Выручка (руб.) & $\begin{array}{l}\text { Разность стоимости реализованного } \\
\text { товара к себестоимости }\end{array}$ \\
\hline Конверсия по звонкам (\%) & $\begin{array}{l}\text { Отношение количества визитов } \\
\text { по звонку к количеству звонков }\end{array}$ \\
\hline $\begin{array}{l}\text { Конверсия по визитам (\%) } \\
\text { ктепень удовлетворенности }\end{array}$ & $\begin{array}{l}\text { Отношение количества продаж } \\
\text { к количеству визитов }\end{array}$ \\
\hline $\begin{array}{l}\text { Возможны два варианта: } \\
\text { 2. Отношенаты опроса после покупки общего количества посту- } \\
\text { пивших жалоб к сумме продаж в штуках }\end{array}$ \\
\hline
\end{tabular}

Базовыми в этом случае показателями остались: коэффициент выполнения плана продаж, выручка и показатель конверсии и по визитам. В перечень ССП для предприятий такого вида добавились следующие показатели: показатель конверсии по звонкам и степень удовлетворенности клиентов. Показатель конверсии по звонкам рассчитывается отношением общего количество визитов по звонку к общему количеству принятых звонков. Визит по звонку - это факт визита потенциального покупателя в компанию как следствие результата договоренностей в момент первичного контакта с представителем компании по телефону. Это первый показатель, на который уровень эмоционального интеллекта, как уже было установлено, оказывает влияние. В перечень ССП был добавлен еще один показа- 
тель - степень удовлетворенности клиентов. На разных предприятиях способ измерения этого показателя может различаться. Если на предприятии есть отдел контроля качества или отдел клиентских отношений, которых проводит опросы по уровню удовлетворенности клиентов, то степень удовлетворенности клиентов рассчитывается по результатам опроса, где на каждый вопрос дается субъективная оценка потребителя по установленной шкале, после чего формируется среднеарифметический показатель, который и выражает степень удовлетворенности потребителя. Этот показатель может рассчитываться как по отделу в целом, так и индивидуально. Влияние уровня эмоционального интеллекта в этом случае неоспоримо. Даже если по каким-то причинам потребитель выказывает недовольство, только в компетенции сотрудника по продажам урегулировать конфликт, настроить потребителя на позитивный лад, сгладить острые углы, чтобы в следующий раз клиент пришел за покупкой именно в эту компанию и именно к этому сотруднику. После измерения уровня эмоционального интеллекта сотрудника выстраивать взаимосвязь и рассчитывать процент влияния уровня эмоционального интеллекта сотрудника на производительность труда и показатели эффективности работы предприятия необходимо на примере выявленных показателей, на которые уровень эмоционального интеллекта влияет.

Рассмотрим четвёртый вид предприятия - «Единороги». Рынок эксклюзивных, люксовых товаров. Объем спроса на таком рынке достаточно невысокий и каждый клиент, каждый контакт с потенциальным потребителем имеет огромное значение для жизнедеятельности предприятия, вопрос уже не только в экономических результатах, таких как прибыль или доля рынка. Вопрос в том, что любые колебания спроса, любая некомпетентность сотрудников может поставить выживаемость такого предприятия под вопрос. Покупатели редки, их потребности - изысканы, их платежеспособность - высока. 
Следовательно, оценка каждого этапа взаимодействия с таким клиентом позволит выявить качество работы сотрудника, его слабые стороны, которые могут оказать негативное влияние на прибыль предприятия, которая формируется не только за счет совершенных сделок, но и количества упущенных возможностей, которые могли появиться на каждом этапе работы специалиста по продажам с потенциальным покупателем. В данном сегменте каждому клиенту необходим индивидуальный подход и намного более длительное общение, которое будет порой выходить за рамки профессионального. В том числе, на это общение влияют и различные техники продаж, среди инструментария которых предусмотрены способы установления доверительных отношений на базе выстроенных личных. Представим предлагаемые показатели для ССП данного вида предприятий в таблице 20.

Таблица 20.

Система сбалансированных показателей для сбытового отдела предприятия вида «Единороги»

\begin{tabular}{|l|l|}
\hline \multicolumn{1}{|c|}{ Показатель } & \multicolumn{1}{|c|}{ Методика расчета } \\
\hline $\begin{array}{l}\text { Коэффициент выполнения } \\
\text { плана продаж (\%) }\end{array}$ & $\begin{array}{l}\text { Отношение факта продаж к плану } \\
\text { продаж }\end{array}$ \\
\hline Выручка (руб.) & $\begin{array}{l}\text { Разность стоимости реализованного } \\
\text { товара к себестоимости }\end{array}$ \\
\hline Конверсия по звонкам (\%) & $\begin{array}{l}\text { Отношение количества визитов по } \\
\text { звонку к количеству звонков }\end{array}$ \\
\hline Конверсия по визитам (\%) & $\begin{array}{l}\text { Отношение количества демонстраций } \\
\text { продукта к количеству визитов }\end{array}$ \\
\hline $\begin{array}{l}\text { Конверсия демонстрации } \\
\text { продукта (\%) }\end{array}$ & $\begin{array}{l}\text { Отношение количества продаж } \\
\text { к количеству демонстраций продукта }\end{array}$ \\
\hline
\end{tabular}


Окончание Таблицы 20.

\begin{tabular}{|l|l|}
\hline & Возможны два варианта: \\
Степень удовлетворенности & 1. Результаты опроса после покупки \\
клиентов (\%) & 2. Отношение общего количества по- \\
& ступивших жалоб к сумме продаж \\
& в штуках \\
\hline
\end{tabular}

В целом, показатели для ССП достаточно схожи с третьим видом, но все же есть пара структурных различий, которым эти два вида, «Рабочие лошади» и «Единороги», отличаются - это способ расчета конверсии по визитам и добавление нового показателя - оценка эффективности демонстрации продукта. Учитывая работу с эксклюзивным товаром, как то автомобили, антиквариат и другие, большую роль играет демонстрация продукта в процессе визита и его презентация в самом выгодном свете, чтобы вызвать у потребителя непреодолимое желание заключить сделку. Демонстрация преимуществ предполагаемого продукта представляет отдельную область, которая разрабатывается специально под каждый вид продукта. Эффективность визита в таком случае считается отношением проведенных демонстраций к общему количеству визитов. Зайти в шоу-рум компании, пообщаться о продукте и узнать цену в случае работы с эксклюзивным товаром может быть недостаточно. Ценник может отпугнуть потенциального клиента, и он может отказаться от покупки, не сумев сопоставить для себя ценность и цену. Именно для этого ключевой задачей специалиста по продажам является склонить во время визита потенциального покупателя к полной и масштабной презентации продукта и предпринять все возможные меры, чтобы любые сомнения во время демонстрации развеялись, и осталась только потребность в приобретении товара. Показатель конверсии демонстрации продукта рассчитывается отношением покупок к общему количеству демонстраций. Этот показатель очень важен, поскольку 
именно благодаря его значению можно определить, все ли возражения преодолел сотрудник отдела продаж и остались ли сомнения у покупателя и какой они природы. Стоит ли дополнительно говорить о том, что уровень эмоционального интеллекта сотрудника обеспечивает максимальную эффективность на каждом из описанных этапов? После измерения уровня эмоционального интеллекта сотрудника выстраивать взаимосвязь и рассчитывать процент влияния уровня эмоционального интеллекта сотрудника на производительность труда и показатели эффективности работы предприятия необходимо на примере выявленных показателей, залогом высоких результатов по которым является уровень эмоционального интеллекта.

На примере данных видов малых предприятий в сфере розничной торговли и предложенных базовых составляющих ССП для каждого из них, можно сделать вывод, что с ростом стоимости товара и увеличением длины сделки, количество этапов, по которым можно оценить эффективность работы сотрудника и его вклад в формирование экономического результата деятельности предприятия, увеличивается. Вместе с увеличением количества таких показателей в структуре ССП увеличивается и уровень влияния эмоционального интеллекта сотрудника на каждом из этих этапов.

В таблице 21 ниже систематизируем полученные результаты. Представим сводную таблицу по показателям в ССП, на выполнение которых влияет эмоциональный интеллект для каждого вида малого предприятия в сфере розничной торговли в таблице. Были предложены точки имплементации показателя уровня эмоционального интеллекта в систему оценки результатов деятельности сбытового отдела. 
Таблица 21.

Место эмоционального интеллекта в системе сбалансированных показателей в зависимости от вида предприятия

\begin{tabular}{|c|c|c|c|}
\hline \multicolumn{4}{|c|}{$\begin{array}{c}\text { Показатели для разных видов малых предприятий розничной торговли, } \\
\text { на которые влияет эмоциональный интеллект }\end{array}$} \\
\hline $\begin{array}{c}\text { Дойные ко- } \\
\text { ровы }\end{array}$ & $\begin{array}{c}\text { Гордые пав- } \\
\text { лины }\end{array}$ & Рабочие лошади & Единороги \\
\hline $\begin{array}{l}\text { Объем вы- } \\
\text { ручки за } \\
\text { транзакцию }\end{array}$ & $\begin{array}{l}\text { Объем вы- } \\
\text { ручки за } \\
\text { транзакцию }\end{array}$ & $\begin{array}{l}\text { Конверсия по } \\
\text { звонкам }\end{array}$ & Конверсия по звонкам \\
\hline \multirow{3}{*}{ Длина чека } & Длина чека & $\begin{array}{l}\text { Конверсия по } \\
\text { визитам }\end{array}$ & Конверсия по визитам \\
\hline & \multirow{2}{*}{$\begin{array}{l}\text { Конверсия по } \\
\text { визитам }\end{array}$} & \multirow{2}{*}{$\begin{array}{l}\text { Степень удовле- } \\
\text { творенности } \\
\text { клиентов }\end{array}$} & $\begin{array}{l}\text { Конверсия демонстра- } \\
\text { ции продукта }\end{array}$ \\
\hline & & & $\begin{array}{l}\text { Степень удовлетворен- } \\
\text { ности клиентов }\end{array}$ \\
\hline
\end{tabular}

На основании вышеописанных данных можно сделать следующие выводы:

- в зависимости от вида малого предприятия розничной торговли существуют разные «точки воздействия» эмоционального интеллекта сотрудника на его производительность и, как следствие, на экономические результаты деятельности предприятия;

- чем больше уровень личного взаимодействия с потребителем, тем больше точек контроля над качеством работы специалиста по продажам;

- чем больше точек контроля качества работы специалиста по продажам, тем больше роль эмоционального интеллекта сотрудника в процессе продажи товаров;

- чем больше роль эмоционального интеллекта сотрудника в процессе продажи товаров и услуг, тем больше необходимость 
предприятия оцифровывать степень влияния эмоционального интеллекта, потому что именно от этого зависит экономический результат деятельности предприятия.

Далее в диссертации будет предложен алгоритм распределения функциональных обязанностей в зависимости от уровня эмоционального интеллекта в отделе сбыта на разных видах малых предприятий в сфере розничной торговли в зависимости от типа менеджера, его сильных и слабых сторон.

\section{2. Алгоритм управления эффективностью деятельности предприятия в зависимости от уровня эмоционального интеллекта}

В процессе исследования результатов опроса и проведения корреляционного и регрессионного анализа были выявлены некие нетипичные значения - выбросы, которые пришлось из состава выборки исключить для обеспечения качества исследования. При детальном анализе выбросов были обозначены некоторые закономерности в производительности труда и уровне эмоционального интеллекта, которые отчасти опровергали выдвинутые гипотезы, но в то же время имели под собой достаточно веские основания и высокую объясняющую способность, например коэффициент вариации среднего значения по выполнению плана продаж по сотруднику был около $40 \%$, и его значимым считать нельзя. Тем не менее в абсолютном выражении этот сотрудник выполнял от 105 до 145 \% ежемесячного плана продаж. В результате были выявлены типы менеджеров по продажам, в зависимости от уровня эмоционального интеллекта и производительности труда. Представим данные по таким сотрудникам в таблице 22. Всего было выделено 61 человек, который не вошел в состав основной выборки из 189 человек. Они были объединены в три группы по уровню эмоционального интеллекта, 
производительность труда по показателям представлена в виде среднего значения по группе.

Таблица 22.

Нетипичные сочетания уровня эмоционального интеллекта и производительности труда

\begin{tabular}{|c|c|c|c|c|}
\hline $\begin{array}{c}\text { Количество } \\
\text { человек } \\
(ш т . ~ / \%)\end{array}$ & $\begin{array}{c}\text { Уровень эмо- } \\
\text { ционального } \\
\text { интеллекта }\end{array}$ & $\begin{array}{c}\text { Коэффициент } \\
\text { выполнения } \\
\text { плана продаж } \\
(\%)\end{array}$ & $\begin{array}{c}\text { Конверсия } \\
\text { по звонкам } \\
(\%)\end{array}$ & $\begin{array}{c}\text { Конверсия } \\
\text { по визитам } \\
(\%)\end{array}$ \\
\hline 12 & $62-76$ & 45 & 12 & 4 \\
\hline 31 & $105-125$ & 60 & 19 & 29 \\
\hline 18 & $80-92$ & 86 & 11 & 18 \\
\hline
\end{tabular}

Графически можно представить не только уже доказанную взаимосвязь, но и характер «выбросов», которые пришлось элиминировать из состава выборки во время исследования на рисунке 19.

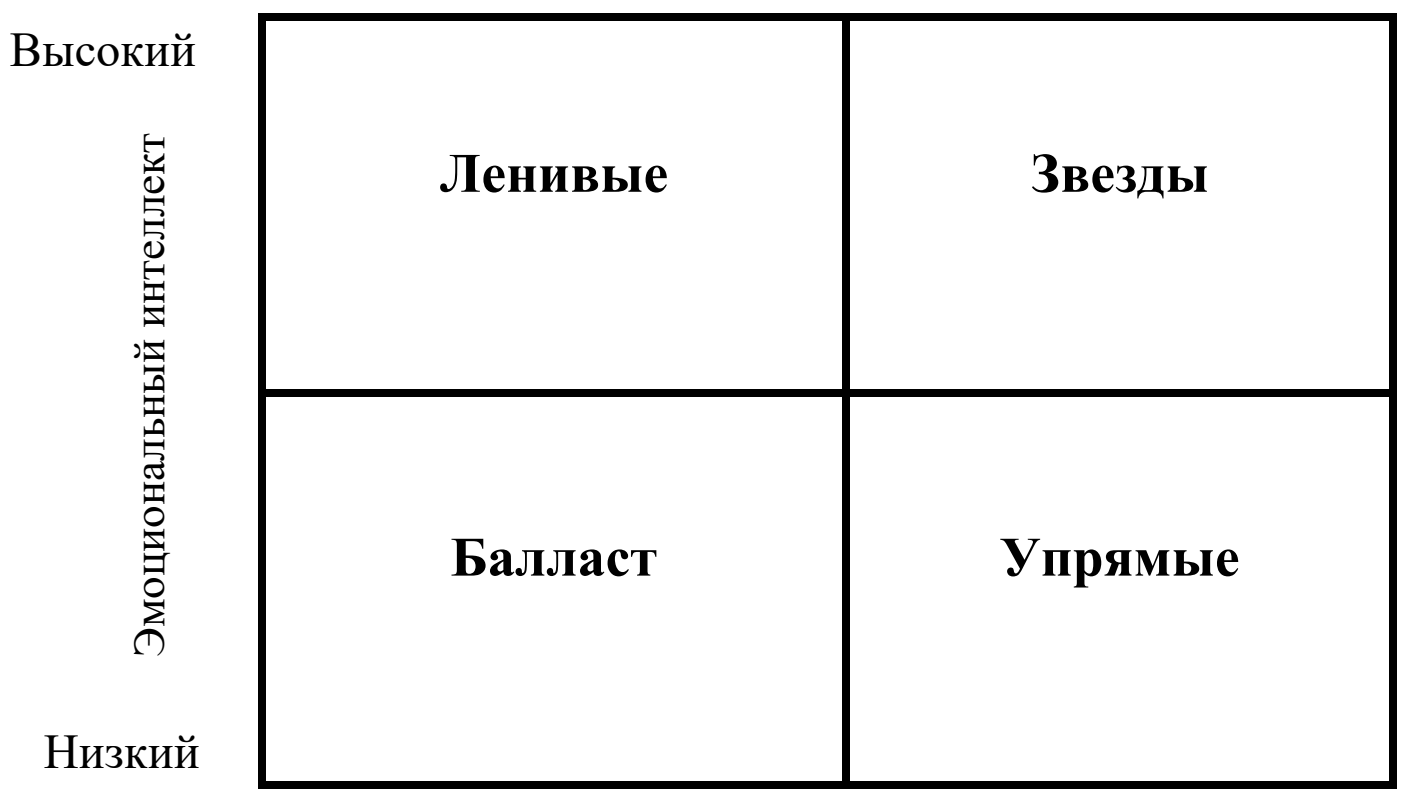

Высокий

Уровень производительности труда

Рисунок 19. Типы сотрудников отдела сбыта 
На рисунке изображены четыре выявленных типа специалистов отдела сбыта: звезды, ленивые, балласт и упрямые. Дадим характеристику каждой из них.

Звездbl - тип сотрудников, которые показывают результаты намного выше среднего, которые выделяются из всего отдела, которые обладают исключительными качествами располагать к себе людей. Объем их продаж не зависит от сезонности, обстановки на рынке и динамики темпов заключения сделок. При самом плохом сценарии они обычно либо выполняют план, либо «недотягивают» минимальный процент до его выполнения. Как правило, эти сотрудники способны продавать товар с большей наценкой, избегать предоставления большого количества скидок. По своей природе звезды - редкие экземпляры и находка для работодателя. В структуре выборки максимальный результат по выполнению планов продаж и уровню эмоционального интеллекта. Коэффициент вариации при анализе среднего был всегда больше 33 \%. С учетом минимального значения выполнения плана в 110 \%, а максимального - $143 \%$.

Упрямые - сотрудники со средним, очень редко низким, уровнем эмоционального интеллекта, но достаточно неплохими результатами. Упрямые - бронепоезд предприятия. При недостатке навыков, умений они обладают высоким уровнем целеустремленности. При этом их результаты тоже можно прогнозировать. Хоть упрямые и не занимают лидирующие позиции в рейтинге отдела по количеству продаж, они отличаются высокой степенью «надежности». Их результаты средние, но они относительно постоянные. Коэффициент вариации при анализе среднего был 15-20\%.

Ленивые - сотрудники с высоким уровнем эмоционального интеллекта, но с низкими результатами по производительности труда. При анализе этой категории выяснилось, что, во-первых, они склонны саботировать рабочий процесс, во-вторых, показатели конверсии по обработке трафика отличаются: процент заключения сделок очень высокий, 
при этом количество встреч и звонков на порядок ниже среднего значения по отделу. Что является подтверждением предположения о саботировании рабочего процесса.

Балласт - категория сотрудников, которые не подходят для роли специалиста по продажам, им не хватает ни социальной чуткости, ни упорства, ни мотивации для того, чтобы вырасти на другой уровень. При этом это могут быть и новые сотрудники, которые еще не адаптировались, или у которых нет совершенно никакого опыта, чтобы сразу же показать уровень своего потенциала. Но эта субкатегория рассматриваться в работе не будет. Эти четыре категории нужны для того, чтобы в предложенном алгоритме расставить по местам не только показатели, на которые влияет уровень эмоционального интеллекта, но и сотрудников. Представим алгоритм распределения функциональных обязанностей эмоционального интеллекта сотрудников на предприятиях типа «Дойная корова» на рисунке 20. 


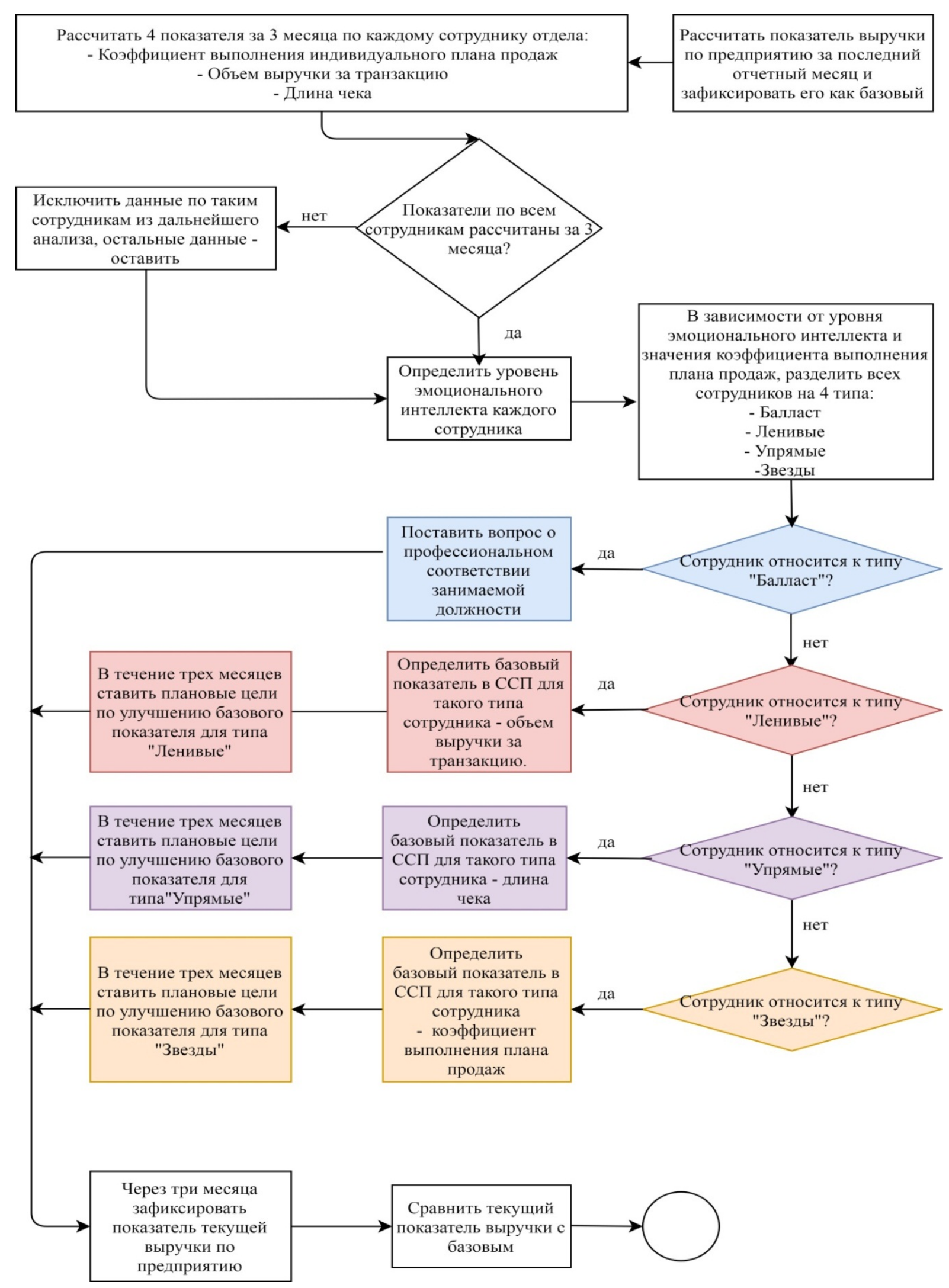

\section{Рисунок 20. Алгоритм распределения функциональных обязанностей на предприятиях вида «Дойная корова»}


Первым шагом необходимо рассчитать показатель выручки предприятия и зафиксировать его как базовый. Далее необходимо минимум за 3 месяца по каждому сотруднику рассчитать три показателя, которые характерны для вида предприятия «Дойная корова»: коэффициент выполнения плана продаж, объем выручки за транзакцию и длину чека. Если показатели по всем сотрудникам не рассчитаны за три месяца, предположим, сотрудник недавно устроился и нельзя еще оценить качество его работы, то такие показатели из данных для оценки исключаются.

После чего определить уровень эмоционального интеллекта каждого сотрудника. Определяется этот уровень прохождением опроса ЭмИН Д.В. Люсина. В зависимости от уровня эмоционального интеллекта по каждому сотруднику и значению показателя выполнения индивидуального плана по продажам определить тип сотрудника: если уровень эмоционального интеллекта высокий, а показатели производительности труда низкие, то это «Ленивые», если наоборот - то «Упрямые», если у сотрудника оба показателя высокие - это «Звезды», а если оба показателя низкие - «Балласт». В зависимости от типа сотрудника, задать каждому базовый показатель. Для «Ленивых» - это объем выручки за транзакцию. Учитывая его высокий уровень эмоционального интеллекта, он способен продавать товар на большие суммы, при этом такая цель по объему выручки с обязательным оперативным контролем способна повысить прибыль предприятия и при этом увеличить качество работы сотрудника с клиентами, а не количество. Для категории «Упрямые» - это длина чека. При прочих равных условиях им тяжелее продавать товар из групп дороже, а предложить сопутствующие товары или товары по акции, для которых не требуется дополнительная аргументация или убеждение - выполнимо. Для «Звезд» основной показатель - коэффициент выполнения плана продаж, причем планы для таких сотрудников должны ставиться амбициозные, но выполнимые и реальные. Далее приведем алгоритм распределения функциональных обязанностей 

ны» на рисунке 21.

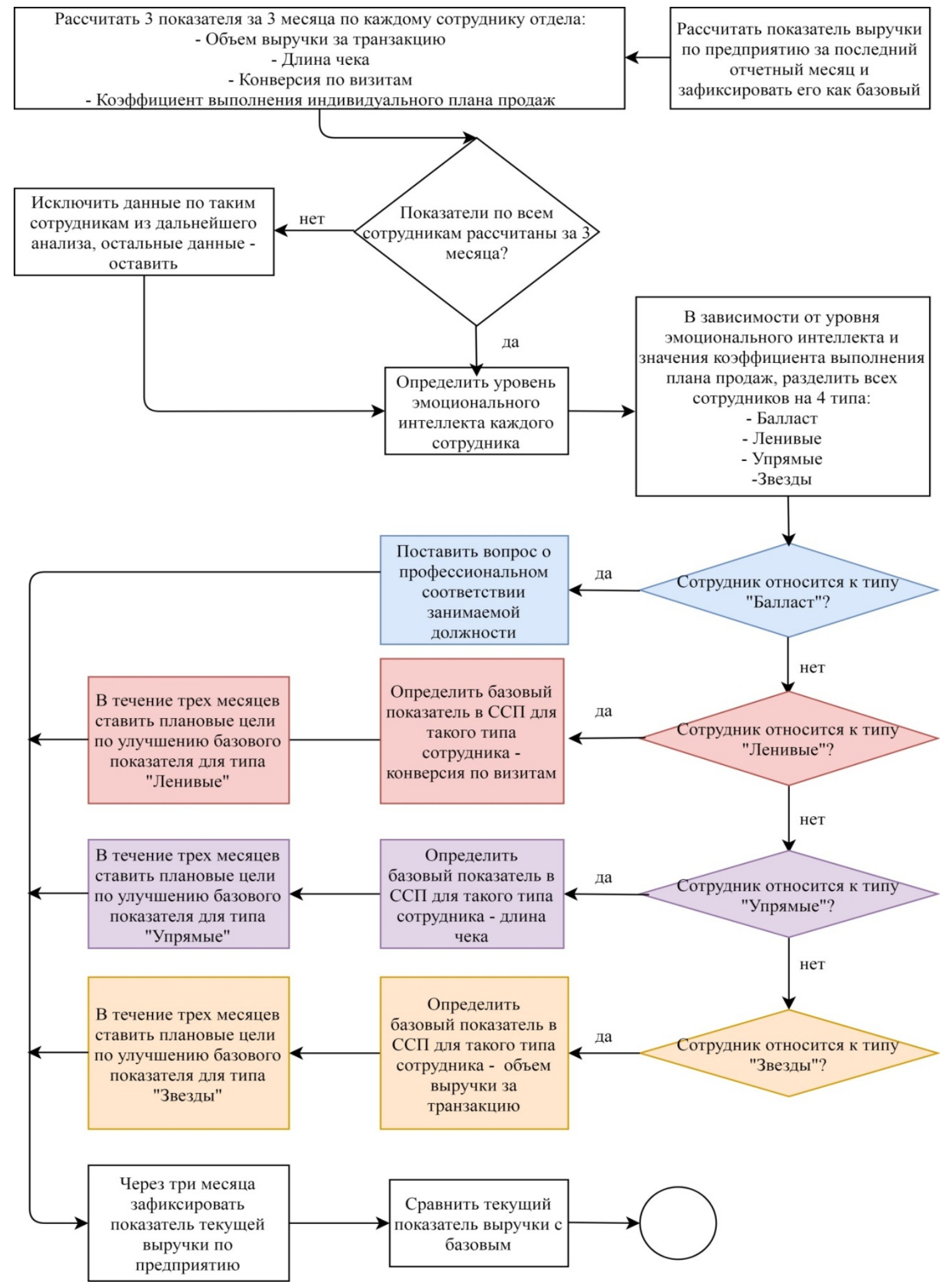

\section{Рисунок 21. Алгоритм распределения функциональных обязанностей} на предприятиях вида «Гордый павлин» 
В случае с предприятием вида «Гордый павлин» меняется перечень базовых показателей производительности труда. Коэффициент выполнения плана продаж входит в алгоритм как один из базовых, но уже для того, чтобы определить тип менеджера, потому что необходимо ставить оперативные задачи непосредственно по тем показателям, которые распределяются в зависимости от слабых и сильных сторон менеджера, что в итоге и приведет к выполнению плана продаж таким сотрудником.

При этом меняются и коэффициенты для основных типов сотрудников. Для «Ленивых» важным становится показатель конверсии по визитам. Данный сотрудник, который порой по своей воле не использует потенциал, должен быть поставлен не в рамки выполнения плана или прибыли, а в рамки ежедневного и обязательного общения с минимумом клиентов. Чтобы обработка входящего клиентского трафика для такого типа сотрудника была не по желанию, а в обязательном порядке, с конкретными плановыми значениями. Только тогда можно будет раскрыть его потенциал и увеличить прибыль предприятия.

По категории «Упрямые» в данном алгоритме тоже изменения не произошли, а вот для категории «Звезды» изменения произошли. Как уже было сказано выше, на предприятиях вида «Гордый павлин» продаются очень дорогие товары, соответственно, необходима дополнительная аргументация со стороны сотрудника отдела продаж, чтобы склонить такого потребителя к покупке более дорогого товара, что таким образом приведет к увеличению прибыли предприятия. Если «Упрямый» сотрудник сможет максимум предложить крем для обуви, то «Звезда» в состоянии продать клиенту более дорогую пару обуви. «Упрямый» сотрудник может не суметь выстроить правильную аргументацию с потенциальным покупателем, а даже при попытке продать более дорогой товар может вызвать негатив у покупа- 
теля. Далее приведем алгоритм распределения функциональных обязанностей на предприятиях вида «Рабочие лошади» на рисунке 22.

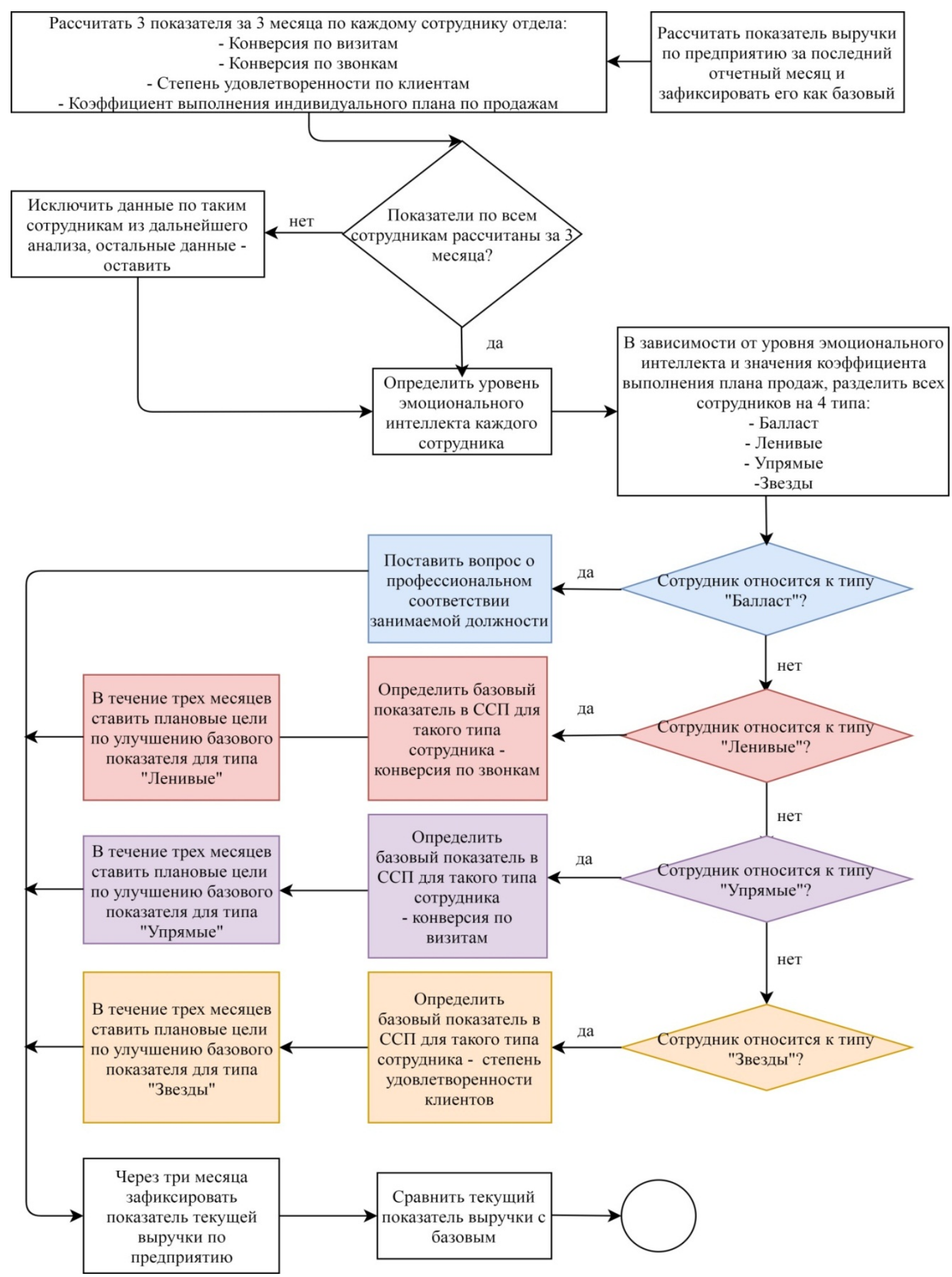

\section{Рисунок 22. Алгоритм распределения функциональных обязанностей на предприятиях вида «Рабочая лошадь»}


Для предприятий вида «Рабочая лошадь» коэффициент выполнения плана продаж также считается основным элементом, который не подлежит дополнительному анализу именно в рамках алгоритма. В алгоритме рассматриваются наиболее узкие области, операции, которые в итоге приводят к выполнению плана, что в свою очередь влияет на экономические результаты деятельности предприятия. В данном случае базовыми показателями являются показатель конверсии по визитам, показатель конверсии по звонкам и степень удовлетворенности клиентов.

Для сотрудников типа «Ленивые» предложен в качестве базового показателя для оценки производительности труда показатель конверсии по звонкам. Уровень эмоционального интеллекта у таких сотрудников высокий, требуется больше усилий, чтобы в процессе телефонного звонка убедить потенциального клиента в необходимости личной встречи. В качестве цели можно предложить постановку количественных значений по ежедневным телефонным контактам. Как уже известно, при личной встрече шанс заключить сделку уже намного больше.

Сотрудникам типа «Упрямые» рекомендуется ставить количественные цели по личным встречам. Шансов достигнуть договоренности о встрече при телефонном разговоре, с учетом среднего уровня эмоционального интеллекта у таких сотрудников, намного меньше, следовательно, таким сотрудникам нет смысла тратить много рабочего времени на телефонные звонки. Им проще сосредоточиться на обработке входящего трафика, потому что сила влияния уровня эмоционального интеллекта при личном общении намного выше.

Сотрудникам вида «Звезды» стоит сконцентрироваться уже на степени удовлетворенности клиентов и заниматься урегулированием возможных конфликтных ситуаций с клиентом, которые могут возникать в процессе совершения сделки. Далее приведем алгоритм 


\section{распределения функциональных обязанностей на предприятиях вида «Единороги» на рисунке 23.}

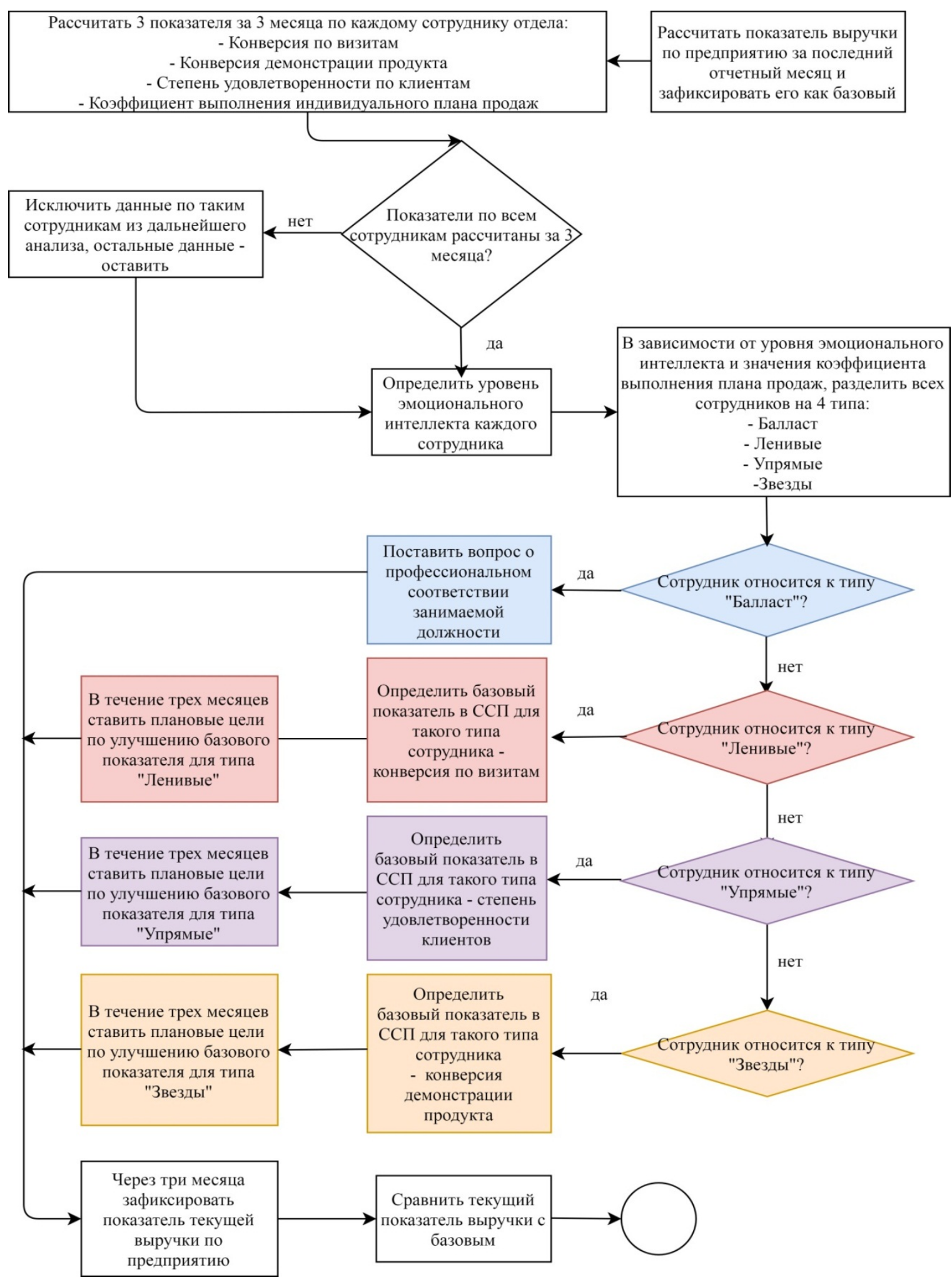

Рисунок 23. Алгоритм оценки влияния эмоционального интеллекта на предприятиях вида «Единороги» 
На предприятиях вида «Единороги» в состав базовых показателей для оценки производительности труда входят: показатель конверсии по визитам, показатель конверсии по демонстрации продукта и степень удовлетворенности клиента. Показатель конверсии по звонкам был убран ввиду специфики продукта на предприятиях вида «Единороги». Человек, который выбирает себе яхту, не будет вести диалоги о цене и комплектации яхты по телефону. Такие диалоги ведутся исключительно при личной встрече. Поэтому такой показатель и был убран из состава базовых. Для «Ленивых» в качестве базового предлагается показатель конверсии по визитам. Их задача в данном случае обрабатывать весь входящий трафик. Для «Упрямых» основная задача - работать над степенью удовлетворенности клиентов посредством качественного выполнения обязанностей по составлению технической документации, полноты спецификации и своевременному выполнению договоренностей с клиентом. На «Звезд» возлагается самая сложная задача - вызвать необходимые эмоции у потенциального потребителя в момент демонстрации товара. Раз у «Звезд» высокий уровень общего эмоционального интеллекта, то, соответственно, и уровень управления эмоциями на межличностном уровне намного выше. Данный показатель не был предложен как базовый для группы «Ленивые», потому что «Ленивые» не склонны обрабатывать достаточное количество трафика по входящим клиентам, чтобы в принципе дойти до этапа демонстрации продукта. По результатам исследований можно сделать следующие выводы:

- в зависимости от стоимости реализуемого товара и длины сделки можно предложить четыре вида предприятия: «Дойные коровы», «Рабочие Лошади», «Единороги» и «Гордые павлины»;

- в зависимости от вида предприятия и специфики работы такого предприятия можно выделить в структуре ССП более релевантные показатели и менее релевантные показатели; 
- на результативность таких показателей влияет уровень эмоционального интеллекта сотрудников, потому что эмоциональный интеллект оказывает прямое воздействие на показатели, где прослеживается прямое взаимодействие между сотрудником и потребителем и косвенное влияние, когда от результата такого взаимодействия зависит общий результат отдела и, как следствие, экономический результат деятельности предприятия;

- всех сотрудников отдела сбыта можно отнести к одному из четырех типов: «Ленивые», «Упрямые», «Звезды» и «Балласт»;

- каждый тип имеет свои сильные и слабые стороны, в зависимости от этого каждому из сотрудников рекомендуется ставить в качестве основного определенные показатели из состава ССП;

Можно также сказать, что не только рынок переходит на формат $\mathrm{H} 2 \mathrm{H}$ - human to human - но и любое взаимодействие даже внутри компании. А такой вид взаимодействия никогда не будет эффективным, если не включать в него компонент эмоционального интеллекта. От эффективности взаимодействия сотрудника и потребителя, начальника и сотрудника зависит общий экономический результат деятельности предприятия. А эффективность взаимодействия зависит от уровня эмоционального интеллекта. Следовательно, от уровня эмоционального интеллекта зависит и экономический результат деятельности предприятия. Более детально данное заключение изложено в третьей части диссертации - апробации предложенных алгоритмов на примере предприятия среднего бизнеса.

\section{3. Апробация результатов исследования}

Для апробации исследования было выбрано предприятие ООО «Концепт Кар». Предприятие на рынке с 2004 года и занимается продажей и ремонтом легковых автомобилей премиум-класса. 
Предприятие относится к средним, численность сотрудников на предприятии более 100 человек. В отделе продаж работают 6 менеджеров, 1 руководитель отдела и 1 логист. При этом 1 менеджер работает на данной позиции более 5 лет, остальные - меньше трех. Апробация проводилась с апреля 2019 года по сентябрь 2019-го включительно.

Данное предприятие можно отнести к категории «Рабочая лошадь», поскольку оно работает с товарами средней ценовой категории со средней и большой длиной сделки. Для начала, в соответствии с алгоритмом, который был предложен ранее, зафиксируем базовые результаты по выручке в марте 2019 года. В марте 2019 года выручка составила 75129 тыс. руб. После чего были рассчитаны показатели эффективности по каждому сотруднику отдела, которые представлены в таблице 23 ниже. Степень удовлетворенности определяется по утвержденной импортером методике и представляет собой опрос покупателей по пятибалльной шкале (1 - наименьшая степень удовлетворенности, 5 - максимальная).

Таблица 23.

Показатели эффективности работы сотрудников предприятия за январь 2018

\begin{tabular}{|c|c|c|c|}
\hline Сотрудник (п/п) & $\begin{array}{c}\text { Конверсия по } \\
\text { звонкам (\%) }\end{array}$ & $\begin{array}{c}\text { Конверсия по } \\
\text { визитам (\%) }\end{array}$ & $\begin{array}{c}\text { Степень удовле- } \\
\text { творенности } \\
\text { (балл) }\end{array}$ \\
\hline 1 & 21 & 37 & 4,91 \\
\hline 2 & 15 & 22 & 4,85 \\
\hline 3 & 19 & 31 & 4,61 \\
\hline 4 & 12 & 28 & 4,92 \\
\hline 5 & 14 & 23 & 4,87 \\
\hline 6 & 11 & 25 & 4,86 \\
\hline
\end{tabular}


После чего был оценен эмоциональный интеллект каждого из сотрудников по методике Д.В. Люсина. Данные представлены в таблице 24. Каждому сотруднику присвоен порядковый номер с 1 по 6.

Таблица 24.

Эмоциональный интеллект сотрудников сбытового отдела предприятия

\begin{tabular}{|c|c|}
\hline Сотрудник (п/п) & Эмоциональный интеллект \\
\hline 1 & 118 \\
\hline 2 & 96 \\
\hline 3 & 110 \\
\hline 4 & 120 \\
\hline 5 & 86 \\
\hline 6 & 92 \\
\hline
\end{tabular}

Необходимо оценить не только эмоциональный интеллект сотрудников предприятия, но и сопоставить его с коэффициентом выполнения индивидуального плана по продажам, чтобы впоследствии разделить сотрудников на виды (данные представлены в таблице 25).

Таблица 25.

Эмоциональный интеллект сотрудников сбытового отдела предприятия и коэффициент выполнения индивидуального

плана по продажам

\begin{tabular}{|c|c|c|}
\hline $\begin{array}{c}\text { Сотрудник } \\
(п / п)\end{array}$ & $\begin{array}{c}\text { Эмоциональный } \\
\text { интеллект }\end{array}$ & $\begin{array}{c}\text { Коэффициент выполнения индиви- } \\
\text { дуального плана по продажам (\%) }\end{array}$ \\
\hline 1 & 118 & 142 \\
\hline 2 & 96 & 89 \\
\hline 3 & 102 & 132 \\
\hline 4 & 120 & 76 \\
\hline 5 & 86 & 97 \\
\hline 6 & 92 & 98 \\
\hline
\end{tabular}


Из таблицы видно, что минимальное значение эмоционального интеллекта в отделе - 86, а максимальное - 120. При этом коэффициент выполнения плана индивидуального плана по продажам колеблется в интервале от 76 до 142 \%. При этом сотрудник № 1 с показателем эмоционального интеллекта в 118 пунктов выполняет план на $142 \%$, в то время как его коллега № 4, имея 120 пунктов эмоционального интеллекта, выполняет план лишь на 76 \%. Чем объясняется результативность сотрудников в одном случае, и чем обусловлены неудачи его работы во втором случае? Для этого необходимо распределить каждого сотрудника на типы, чтобы определить характер его сильных и слабых сторон и в соответствии с этим распределить функциональные обязанности.

Для этого построим график и схематично разделим его на 4 части. Таким образом, можно графически представить положение каждого сотрудника в зависимости от его результатов на рисунке 24 .

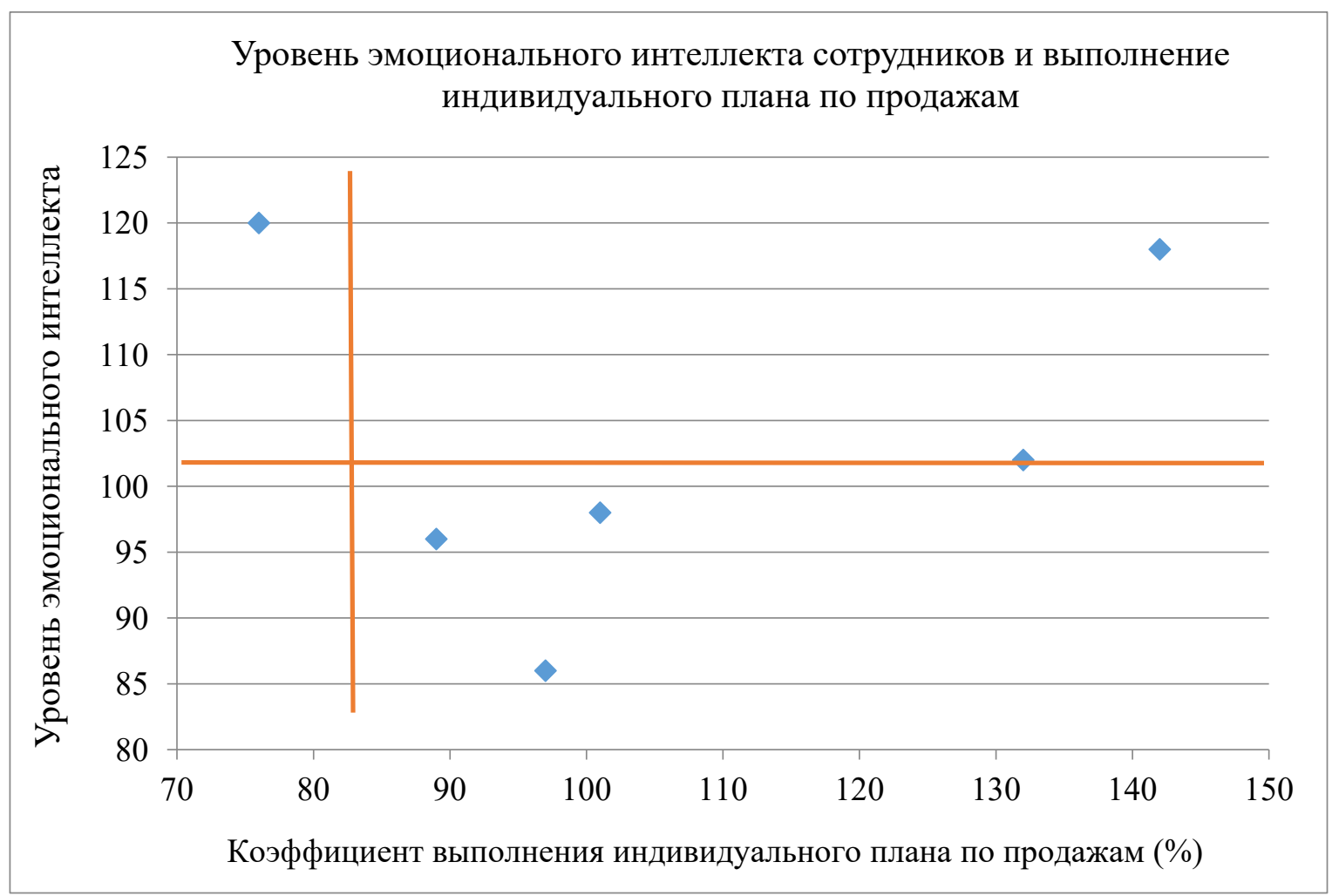

Рисунок 24.Уровень эмоционального интеллекта сотрудников и выполнение индивидуального плана по продажам 
На графике видно, что в отделе нет неэффективных сотрудников и с низким уровнем эмоционального интеллекта, и с низкими результатами по выполнению индивидуального плана по продажам это сотрудник № 4. Далее смотрим на коэффициенты эффективности сотрудника № 4 - $12 \%$ приходят к нему на личную встречу, а результат по отделу по конверсии по визитам - чуть ли не один из самых лучших (28 \%). Стоит посмотреть детально отчеты по входящему трафику, чтобы увидеть абсолютное выражение такого результата. Так, если в среднем каждый принимает примерно по 5-6 потенциальных покупателей в день, сотрудник № 4 принимает в среднем по два. $28 \%$ его эффективности распространяются на 2 человека в среднем, а не на 5 или 6 как у среднестатистического сотрудника. Его можно определить под тип «Ленивых», потому что он не использует свой потенциал. Данные по входящему трафику ведутся на предприятии, согласно внутренним регламентам. Напомним, что одним из условий разработки и внедрения предложенных алгоритмов являлось также и наличие методики по фиксации и обработке сотрудниками потоков клиентов в CRM системе, чтобы можно было, как в этом случае с сотрудником № 4, определить истинные причины его нерезультативности.

В отделе работают два сотрудника типа «Звезды» - это сотрудник № 1 и 3. Их результаты выше средних по отделу и по уровню результативности по выполнению плана и по конверсии промежуточных этапов работы. Также в отделе есть два «Упрямых» - это № 2, 5 и 6. Они достигают средних результатов по всем показателям.

В соответствии с алгоритмом, после того как были выявлены типы сотрудников, следует концентрировать их усилия в рамках тех показателей, которые были указаны в алгоритме. Представим данные в следующей таблице 26. 
Таблица 26.

Определение основных показателей эффективности для каждого сотрудника отдела сбыта в зависимости от типа сотрудника

\begin{tabular}{|c|c|c|}
\hline $\begin{array}{c}\text { Сотрудник } \\
(п / п)\end{array}$ & Тип & Ключевой показатель эффективности \\
\hline 1 & Звезда & Степень удовлетворенности клиентов \\
\hline 2 & Упрямый & Конверсия по визитам \\
\hline 3 & Звезда & Степень удовлетворенности клиентов \\
\hline 4 & Ленивый & Конверсия по звонкам \\
\hline 5 & Упрямый & Конверсия по визитам \\
\hline 6 & Упрямый & Конверсия по визитам \\
\hline
\end{tabular}

После того как были определены ключевые показатели эффективности в зависимости от типа сотрудника, руководителю подразделения необходимо, в первую очередь, ставить целевые значения по таким показателям в первую очередь. Например, для типа «Упрямый» - были поставлены значения по обработке ежедневных визитов, типу «Ленивый» - ежедневное количество звонков. Для типа «Звезда» главным показателем является степень удовлетворенности. Руководитель отдела должен каждый месяц ставить плановые показатели каждому типу сотрудников по выбранному в соответствии с алгоритмом показателю. Приведем пример постановки таких плановых значений на ежемесячной основе в таблице 27 ниже. Причем значения плановых показателей должны быть не относительными, а абсолютными. Потому что, как было продемонстрировано на примере сотрудника № 4, конверсия по визитам в 28 \% может ни о чем не говорить, хотя и считаться одним из лучших показателей по отделу. 
Таблица 27.

Постановка целей по каждому сотруднику в зависимости

от показателя

\begin{tabular}{|c|c|c|c|c|}
\hline $\begin{array}{l}\text { Сотруд- } \\
\text { ник (п/п) }\end{array}$ & $\begin{array}{l}\text { Тип со- } \\
\text { трудника }\end{array}$ & $\begin{array}{c}\text { Основной показатель } \\
\text { в зависимости от ви- } \\
\text { да сотрудника }\end{array}$ & $\begin{array}{c}\text { Фактическое } \\
\text { значение в } \\
\text { марте } 2019\end{array}$ & $\begin{array}{c}\text { Плановое } \\
\text { значение } \\
\text { на апрель } \\
2019\end{array}$ \\
\hline 1 & Звезда & $\begin{array}{l}\text { Степень удовлетво- } \\
\text { ренности клиентов } \\
\text { (от } 1 \text { до 5) }\end{array}$ & 4,91 & 4,92 \\
\hline 2 & Упрямый & $\begin{array}{l}\text { Количество визитов } \\
\text { в месяц (шт.) }\end{array}$ & 25 & 30 \\
\hline 3 & Звезда & $\begin{array}{l}\text { Степень удовлетво- } \\
\text { ренности клиентов } \\
\text { (от } 1 \text { до 5) }\end{array}$ & 4,61 & 4,68 \\
\hline 4 & Ленивый & $\begin{array}{l}\text { Количество звонков } \\
\text { в месяц (шт.) }\end{array}$ & 21 & 28 \\
\hline 5 & Упрямый & $\begin{array}{l}\text { Количество визитов } \\
\text { в месяц (шт.) }\end{array}$ & 19 & 24 \\
\hline 6 & Упрямый & $\begin{array}{l}\text { Количество визитов } \\
\text { в месяц (шт.) }\end{array}$ & 23 & 26 \\
\hline
\end{tabular}

Плановые значения были заданы руководителем отдела в зависимости от: количества рабочих смен сотрудника и других факторов, которые могут влиять на оптимальную постановку планов внутри отдела. И каждый месяц эти планы обновлялись в зависимости от рыночной ситуации и с привязкой к общему плану продаж. С апреля 2019 года каждый месяц руководитель отдела на ежемесячной основе, в первую очередь, ставил планы по основному показателю для каждого сотрудника в зависимости от его типа. Оценим динамику основных показателей по каждой группе сотрудников с апреля 2019 
по сентябрь 2019 года. В первую очередь в таблице 28 рассмотрим, как менялся основной показатель «Степень удовлетворенности клиентов» у сотрудников типа «Звезда». У таких сотрудников высокий и уровень общего эмоционального интеллекта, и выше среднего показатели эффективности его работы по продажам, конверсии по звонкам и конверсии по визитам.

Таблица 28.

Изменение основного показателя по сотрудникам типа «Звезда» с апреля по сентябрь 2019 года

\begin{tabular}{|c|c|c|c|c|c|c|}
\hline \multirow{2}{*}{$\begin{array}{c}\text { Сотрудник } \\
(п / \Pi)\end{array}$} & \multicolumn{5}{|c|}{ Степень удовлетворенности клиентов с апреля по сентябрь } \\
\cline { 2 - 7 } & Апрель & Май & Июнь & Июль & Август & Сентябрь \\
\hline 1 & 4,95 & 4,95 & 4,96 & 4,94 & 4,96 & 4,97 \\
\hline 3 & 4,76 & 4,79 & 4,82 & 4,83 & 4,82 & 4,85 \\
\hline
\end{tabular}

По первому сотруднику можно сделать следующие выводы: в сентябре 2019 года степень удовлетворенности выросла на 0,01, по сравнению с апрелем 2019-го наблюдается прирост значения показателя на 0,02. По третьему сотруднику в сентябре 2019 года степень удовлетворенности клиентов увеличилась на 0,03, по сравнению с апрелем 2019-го наблюдается прирост значения показателя на 0,09 пункта, при этом базисный темп прироста составил 1,9\%. Степень удовлетворенности клиентов выросла у двух сотрудников вида «Звезда».

Для сотрудников № 2, 5 и 6, которые были определены, как «Упрямые», основным показателем, согласно алгоритму, является конверсия по визитам. Рассмотрим, как менялся основной показатель для расчета конверсии по визитам у сотрудников типа «Упрямые» в таблице 29. 
Таблица 29.

Изменение основного показателя по сотрудникам типа «Упрямые» с апреля по сентябрь 2019 года

\begin{tabular}{|c|c|c|c|c|c|c|}
\hline \multirow{2}{*}{$\begin{array}{c}\text { Сотрудник } \\
(\text { п/п) }\end{array}$} & \multicolumn{5}{|c|}{ Количество визитов с июня по ноябрь 2019 года (чел.) } \\
\cline { 2 - 7 } & Апрель & Май & Июнь & Июль & Август & Сентябрь \\
\hline 2 & 7 & 9 & 6 & 8 & 10 & 11 \\
\hline 5 & 5 & 6 & 9 & 7 & 11 & 12 \\
\hline 6 & 9 & 7 & 5 & 8 & 11 & 13 \\
\hline
\end{tabular}

Типу «Упрямые» необходимо ставить увеличение этого количества потому, что уровень эмоционального интеллекта у них ниже, соответственно, точку приложения эмоционального интеллекта при телефонном разговоре им использовать намного сложнее. Переориентируя их рабочее время на встречи, таким образом, можно увеличить и их продажи. По второму сотруднику в сентябре 2019 года количество встреч выросло на 1 человека, по сравнению с апрелем 2019-го наблюдается прирост значения показателя на 4 человек. По пятому сотруднику в сентябре 2019 года также количество встреч с потенциальными покупателями увеличилось на 1, причем по сравнению с апрелем 2019 года наблюдается прирост значения показателя на 7 человек. По сотруднику № 6 в сентябре количество визитов возросло на 2 человека, по сравнению с апрелем 2019-го наблюдается прирост количества визитов на 4 человека. В случае с этим показателем можно уже перенести результаты из плоскости показателей производительности труда в плоскость показателей по продажам. Для этого для начала представим данные по продажам, количеству визитов и конверсии по визитам до проведения апробации. В таблице 30 ниже представим количество продаж по каждому сотруднику типа «Упрямые», которые были совершены вследствие визита потенциального покупателя. Возьмем аналогичный период за прошлый 
2018 год: так можно сразу же исключить погрешность сезонности. Сравнивать вторую половину года с началом года было бы не совсем корректно.

Таблица 30.

Изменение объема продаж по сотрудникам типа «Упрямые» с апреля по сентябрь 2018 года

\begin{tabular}{|c|c|c|c|c|c|c|c|}
\hline \multirow{2}{*}{$\begin{array}{c}\text { Co- } \\
\text { труд } \\
\text { ник } \\
(п / п)\end{array}$} & \multirow[b]{2}{*}{$\begin{array}{c}\text { Значение основного } \\
\text { показателя }\end{array}$} & \multicolumn{6}{|c|}{ Период } \\
\hline & & Апрель & Май & Июнь & Июль & $\begin{array}{l}\text { Ав- } \\
\text { густ }\end{array}$ & $\begin{array}{l}\text { Сен- } \\
\text { тябрь }\end{array}$ \\
\hline \multirow{3}{*}{2} & $\begin{array}{l}\text { Кол-во визитов } \\
\text { (чел.) }\end{array}$ & 6 & 6 & 5 & 7 & 8 & 10 \\
\hline & $\begin{array}{l}\text { Конверсия по визи- } \\
\text { там (\%) }\end{array}$ & 21 & 22 & 20 & 25 & 24 & 24 \\
\hline & Продажи (шт.) & 1 & 1 & 1 & 2 & 2 & 2 \\
\hline \multirow{3}{*}{5} & $\begin{array}{l}\text { Кол-во визитов } \\
\text { (чел.) }\end{array}$ & 5 & 6 & 7 & 6 & 7 & 9 \\
\hline & $\begin{array}{l}\text { Конверсия по визи- } \\
\text { там (\%) }\end{array}$ & 23 & 24 & 23 & 22 & 23 & 24 \\
\hline & Продажи (шт.) & 1 & 1 & 2 & 1 & 2 & 2 \\
\hline \multirow{3}{*}{6} & $\begin{array}{l}\text { Кол-во визитов } \\
\text { (чел.) }\end{array}$ & 7 & 6 & 6 & 9 & 10 & 10 \\
\hline & $\begin{array}{l}\text { Конверсия по визи- } \\
\text { там (\%) }\end{array}$ & 25 & 24 & 23 & 22 & 25 & 27 \\
\hline & Продажи (шт.) & 2 & 1 & 1 & 2 & 2 & 3 \\
\hline
\end{tabular}

Сотрудник № 2 всего провел 42 встречи за этот период, средний показатель конверсии по визитам составил 22,6 \%, и при этом он заключил 9 сделок. Сотрудник № 5 провел 40 встреч, средний показа- 
тель конверсии $23 \%$, количество продаж - 9 штук. Сотрудник № 6 всего провел 48 встреч, из них 11 потенциальных покупателей совершили покупку, а конверсия составила в среднем примерно 24,6 \%.

Во время проведения апробации основное рабочее время таких сотрудников перераспределилось с других видов деятельности на визиты преимущественно. Стоит сказать, что изначально для апробации было взято непростое предприятие. Легче было бы взять за основу масс-сегмент товаров, в котором конверсия считается от десятков, а не от штук. Тем не менее даже на примере такого предприятия можно сравнить результаты до апробации и после. В следующей таблице 31 будут представлены данные с апреля по сентябрь 2019 года, за этот период каждому из сотрудников выставлялись абсолютные цели по визитам, для расчета конверсии.

Таблица 31.

Изменение объема продаж по сотрудникам типа «Упрямые»

с апреля по сентябрь 2019 года

\begin{tabular}{|c|c|c|c|c|c|c|c|}
\hline \multirow{2}{*}{$\begin{array}{l}\text { Cо- } \\
\text { труд } \\
\text { ник } \\
(п / \Pi)\end{array}$} & \multirow[b]{2}{*}{$\begin{array}{c}\text { Значение основного по- } \\
\text { казателя }\end{array}$} & \multicolumn{6}{|c|}{ Период } \\
\hline & & $\begin{array}{l}\text { Ап- } \\
\text { рель }\end{array}$ & Май & Июнь & Июль & $\begin{array}{l}\text { Ав- } \\
\text { густ }\end{array}$ & $\begin{array}{l}\text { Сен- } \\
\text { тябрь }\end{array}$ \\
\hline \multirow{3}{*}{2} & Кол-во визитов (чел.) & 7 & 9 & 6 & 8 & 10 & 11 \\
\hline & $\begin{array}{l}\text { Конверсия по визитам } \\
(\%)\end{array}$ & 22 & 22 & 25 & 20 & 23 & 24 \\
\hline & Продажи (шт.) & 1 & 2 & 2 & 2 & 2 & 3 \\
\hline \multirow{3}{*}{5} & Кол-во визитов (чел.) & 5 & 6 & 9 & 7 & 11 & 12 \\
\hline & $\begin{array}{l}\text { Конверсия по визитам } \\
(\%)\end{array}$ & 23 & 22 & 23 & 21 & 23 & 25 \\
\hline & Продажи (шт.) & 1 & 1 & 2 & 1 & 3 & 3 \\
\hline
\end{tabular}


Окончание Таблицы 31.

\begin{tabular}{|c|l|c|c|c|c|c|c|}
\hline \multirow{2}{*}{6} & Кол-во визитов (чел.) & 9 & 7 & 5 & 8 & 11 & 13 \\
\cline { 2 - 8 } & $\begin{array}{l}\text { Конверсия по визитам } \\
(\%)\end{array}$ & 25 & 25 & 22 & 26 & 25 & 24 \\
\cline { 2 - 8 } & Продажи (шт.) & 2 & 2 & 1 & 2 & 3 & 3 \\
\hline
\end{tabular}

Сотрудник № 2 всего провел 51 встречу за этот период, средний показатель конверсии по визитам составил 22,6 \%, и при этом он заключил 12 сделок. Сотрудник № 5 провел 50 встреч, средний показатель конверсии 22,8 \%, количество продаж - 11 штук. Сотрудник № 6 всего провел 53 встречи, из них 13 потенциальных покупателей совершили покупку, а конверсия составила в среднем примерно 25 \%.

Сравнивая две таблицы, можно отметить, что общее количество встреч по всем сотрудникам возросло на 18,5 \%, с 130 штук до 154. При этом продажи увеличились на 7 штук, с 29 до 36. Количественный показатель продаж может быть и нельзя назвать внушительным, но для премиума-бренда в текущей рыночной ситуации 7 автомобилей - 1/3 ежемесячного плана отдела. В данном случае относительный показатель более информативен, чем абсолютный. На показатель визитов могли повлиять и другие факторы, например, рост активности потребителей на этом рынке, результат более сильной маркетинговой стратегии с 2019 году по сравнению с 2018-м, выход новых моделей и так далее.

Для примера в таблице 32 ниже предоставим данные по визитам по другим сотрудникам, показатель конверсии по визитам для которых, согласно алгоритму, не является основным. 
Таблица 32.

Изменение основного показателя по сотрудникам типа «Звезда» и «Ленивый» с апреля по сентябрь 2018 года

\begin{tabular}{|c|c|c|c|c|c|c|}
\hline \multirow{2}{*}{$\begin{array}{c}\text { Сотрудник } \\
\text { (п/п) }\end{array}$} & \multicolumn{5}{|c|}{ Количеств визитов с апреля по сентябрь 2018 года (чел.) } \\
\cline { 2 - 7 } & Апрель & Май & Июнь & Июль & Август & Сентябрь \\
\hline 1 & 6 & 7 & 5 & 8 & 9 & 9 \\
\hline 3 & 6 & 6 & 8 & 9 & 7 & 10 \\
\hline 4 & 5 & 7 & 7 & 8 & 10 & 8 \\
\hline
\end{tabular}

Всего сотрудник № 1 провел 44 встречи, сотрудник № 3 - 46, и сотрудник № 4 - 45 соответственно. Всего они провели 135 встреч. Представим ниже в таблице 33 данные за аналогичный период за 2019 год.

Таблица 33.

Изменение основного показателя по сотрудникам типа «Звезда» и «Ленивый» с апреля по сентябрь 2019 года Сотрудник Количество визитов с апреля по сентябрь 2019 года (чел.)

\begin{tabular}{|c|c|c|c|c|c|c|}
\hline$(\Pi / п)$ & Апрель & Май & Июнь & Июль & Август & Сентябрь \\
\hline 1 & 7 & 5 & 7 & 7 & 8 & 11 \\
\hline 3 & 8 & 6 & 8 & 7 & 5 & 6 \\
\hline 4 & 5 & 6 & 6 & 7 & 10 & 8 \\
\hline
\end{tabular}

Всего сотрудник № 1 провел 45 встреч, сотрудник № $3-40$, и сотрудник № $4-42$ соответственно. Всего они провели 127 встреч. Общее количество встреч в 2019 году практически не изменилось, в то время как в группе, где количество встреч являлось обязательным контрольным показателем, количество встреч увеличилось значительно. Учитывая, что сотрудники типа «Звезда» и «Ленивый» об- 
ладают изначально большим уровнем эмоционального интеллекта и большим значением конверсии по визитам, в 2018 году проведя 135 встречу, они продали 43 автомобиля, а в 2019 году - 46 автомобилей.

Рассмотрим, как изменились показатели по сотруднику № 4 в таблице 34. Тип сотрудника - «Ленивый». Основной показатель конверсия по звонкам, которая рассчитывается на основании количества общих звонков. Представим данные за два периода - до и вовремя апробации - и перенесем эти данные сразу же из плоскости производительности труда специалиста в область объема продаж, которая влияет в итоге и на выручку предприятия. Стоит еще раз отметить, что между звонком и продажей может стоять и промежуточный показатель - конверсия по визитам. Если в случае с предыдущей группой сотрудников показатель конверсии был одномерным, то в случае с конверсией по звонкам, чтобы проанализировать влияние роста количества звонков на продажи, потребуется немного больше действий.

Таблица 34.

Изменение показателя количества звонков с апреля по сентябрь 2018 года для сотрудника типа «Ленивый»

\begin{tabular}{|c|c|c|c|c|c|c|c|}
\hline \multirow{2}{*}{$\begin{array}{c}\text { Cо- } \\
\text { труд } \\
\text { ник } \\
(\text { п/п) }\end{array}$} & \multirow[b]{2}{*}{$\begin{array}{c}\text { Значение основного } \\
\text { показателя }\end{array}$} & \multicolumn{6}{|c|}{ Период } \\
\hline & & $\begin{array}{l}\text { Ап- } \\
\text { рель }\end{array}$ & Май & Июнь & Июль & $\begin{array}{l}\text { Ав- } \\
\text { густ }\end{array}$ & $\begin{array}{l}\text { Сен- } \\
\text { тябрь }\end{array}$ \\
\hline \multirow{4}{*}{4} & $\begin{array}{l}\text { Количество звонков } \\
\text { (шт.) }\end{array}$ & 19 & 18 & 21 & 17 & 20 & 23 \\
\hline & $\begin{array}{l}\text { Конверсия по звон- } \\
\text { кам (\%) }\end{array}$ & 12 & 11 & 15 & 13 & 12 & 14 \\
\hline & $\begin{array}{l}\text { Количество визитов } \\
\text { (чел.) }\end{array}$ & 2 & 2 & 3 & 2 & 2 & 3 \\
\hline & Объем продаж (шт.) & 1 & 0 & 1 & 1 & 1 & 2 \\
\hline
\end{tabular}


Всего за период к сотруднику № 4 позвонило 118 человек, из которых 15 в итоге пришли на личную встречу, из 15 человек 6 встреч закончились покупкой. Представим данные с июня по ноябрь за 2019 год в таблице 35.

Таблица 35.

Изменение показателя количества звонков с апреля по сентябрь 2019 года для сотрудника типа «Ленивый»

\begin{tabular}{|c|c|c|c|c|c|c|c|}
\hline \multirow{2}{*}{$\begin{array}{c}\text { Со- } \\
\text { труд } \\
\text { ник } \\
(п / п)\end{array}$} & \multirow{2}{*}{$\begin{array}{c}\text { Значение основного } \\
\text { показателя }\end{array}$} & \multicolumn{6}{|c|}{ Период } \\
\hline & & $\begin{array}{l}\text { Ап- } \\
\text { рель }\end{array}$ & Май & Июнь & Июль & $\begin{array}{l}\text { Ав- } \\
\text { густ }\end{array}$ & $\begin{array}{l}\text { Сен- } \\
\text { тябрь }\end{array}$ \\
\hline \multirow{4}{*}{4} & $\begin{array}{l}\text { Количество звонков } \\
\text { (шт.) }\end{array}$ & 23 & 24 & 21 & 26 & 27 & 30 \\
\hline & $\begin{array}{l}\text { Конверсия по звон- } \\
\text { кам (\%) }\end{array}$ & 15 & 16 & 14 & 16 & 14 & 15 \\
\hline & $\begin{array}{l}\text { Количество визитов } \\
\text { (чел.) }\end{array}$ & 3 & 4 & 3 & 4 & 4 & 5 \\
\hline & Объем продаж (шт.) & 1 & 2 & 1 & 2 & 1 & 2 \\
\hline
\end{tabular}

В 2019 году с апреля по сентябрь сотрудник № 4 обработал всего 151 звонок, из которых уже 23 человека пришли на личную встречу, из 23 человек уехали из салона на новом автомобиле 9. То есть увеличивая количество звонков и работая непосредственно с этим показателем не только в абсолютном, но и относительном выражении, можно увеличить и количество потенциальных покупателей, которые приходят на личную встречу. А уже при личной встрече у такого вида сотрудников открываются большие возможности для применения своих талантов, которые обоснованы уровнем эмоционального интеллекта, чтобы склонить покупателя к заключению контракта. На микроуровне было изучено воздействие предложенно- 
го алгоритма на производительность труда каждого из сотрудников, по результатам апробации можно сделать определенные выводы: удовлетворенность клиентов у сотрудников типа «Звезда» увеличилось в сумме на 0,11 пункта, количество визитов у сотрудников типа «Упрямые» увеличилось на 24 человека, или на 18,5 \%, что позволило увеличить продажи на 7 штук, или на $24 \%$. Количество звонков у сотрудника типа «Ленивый» увеличилось на 33 штуки, или 28 \%, причем объем продаж вырос на 3 автомобиля, или на $50 \%$, после внедрения работы предприятия в соответствии с предлагаемым алгоритмом. Суть данного алгоритма заключается, в первую очередь, в распределении функциональных обязанностей на основе типа сотрудника, который определяется уровнем его эмоционального интеллекта и результативностью. В алгоритме указан основной показатель, на который должен ориентироваться предприниматель, но никто не запрещает ему работать и с остальными показателями конверсии, которые могут быть рассчитаны в отделе продаж. Вопрос в оптимальном распределении нагрузки на каждого сотрудника отдела исходя из его предрасположенности и талантов. Далее представим результаты апробации уже на уровне предприятия, рассмотрев изменения ключевых показателей экономической деятельности: выручки, прибыли, рентабельности от продаж, объема продаж в штуках и доли рынка за два периода: с апреля по сентябрь 2018 года и с апреля по сентябрь 2019 года. Для начала рассмотрим динамику объема продаж на предприятии с апреля по сентябрь в 2018 и 2019 годах соответственно (рисунок 25). 


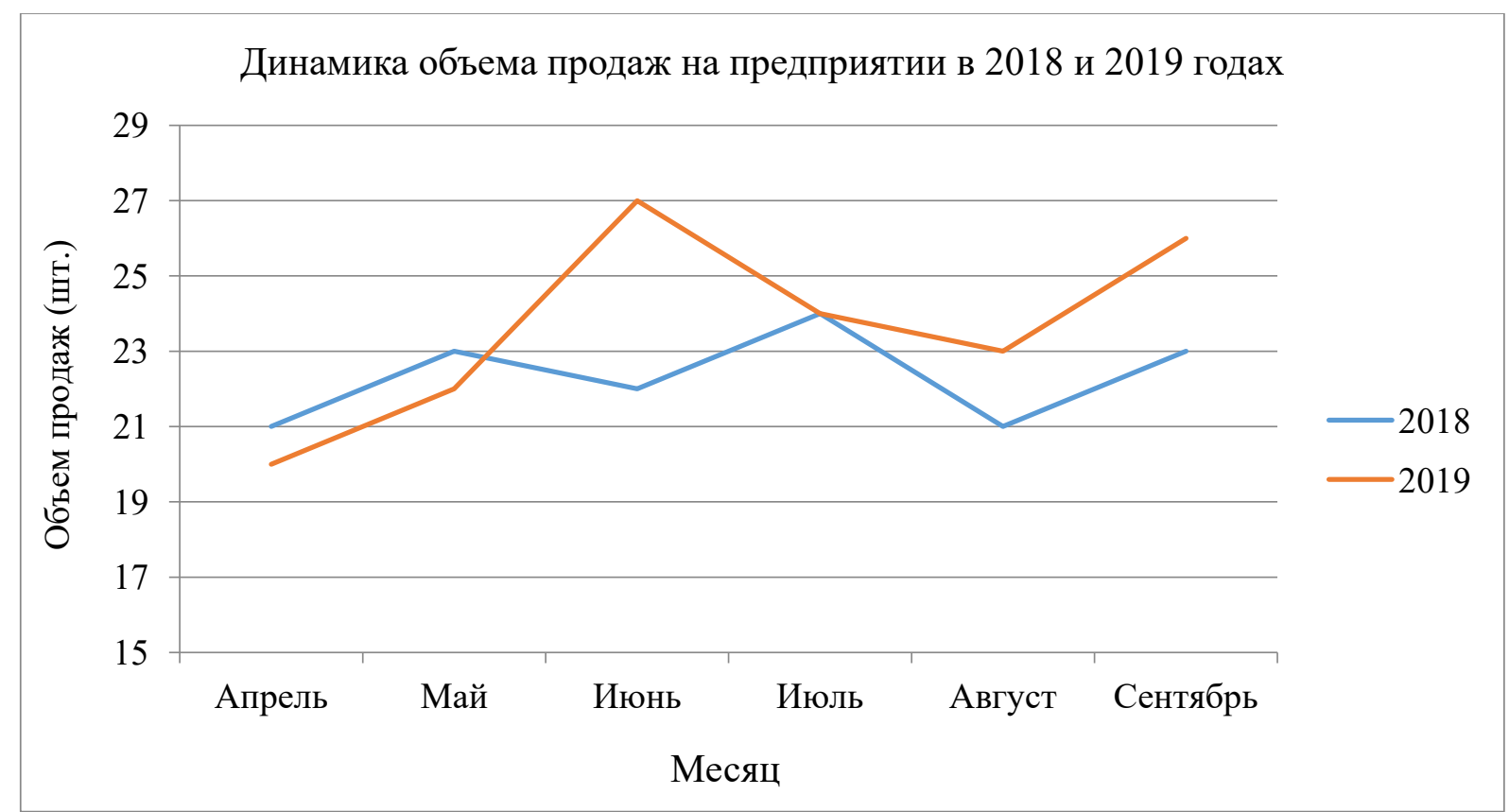

Рисунок 25. Динамика объема продаж на предприятии в 2018 и 2019 гг.

В 2018 году с апреля по сентябрь было продано 134 автомобиля, минимальное значение ежемесячного объема продаж - 21 автомобиль, максимальное - 24, среднее значение 22 автомобиля. В 2019 году с апреля по сентябрь было продано 142 автомобиля, минимальное значение ежемесячного объема продаж - 20 автомобилей, а максимальное - 27 автомобилей, среднее значение объема продаж за период 24 автомобиля. В 2019 году по сравнению с 2018-м было продано больше на 8 автомобилей, темп прироста составил 6 \%. После внедрения в мае 2019 года алгоритма распределения функциональных обязанностей сотрудников отдела продаж наблюдается рост объема продаж по сравнению с сопоставимым периодом предыдущего года. Далее на рисунке 26 представим динамику выручки предприятия. 


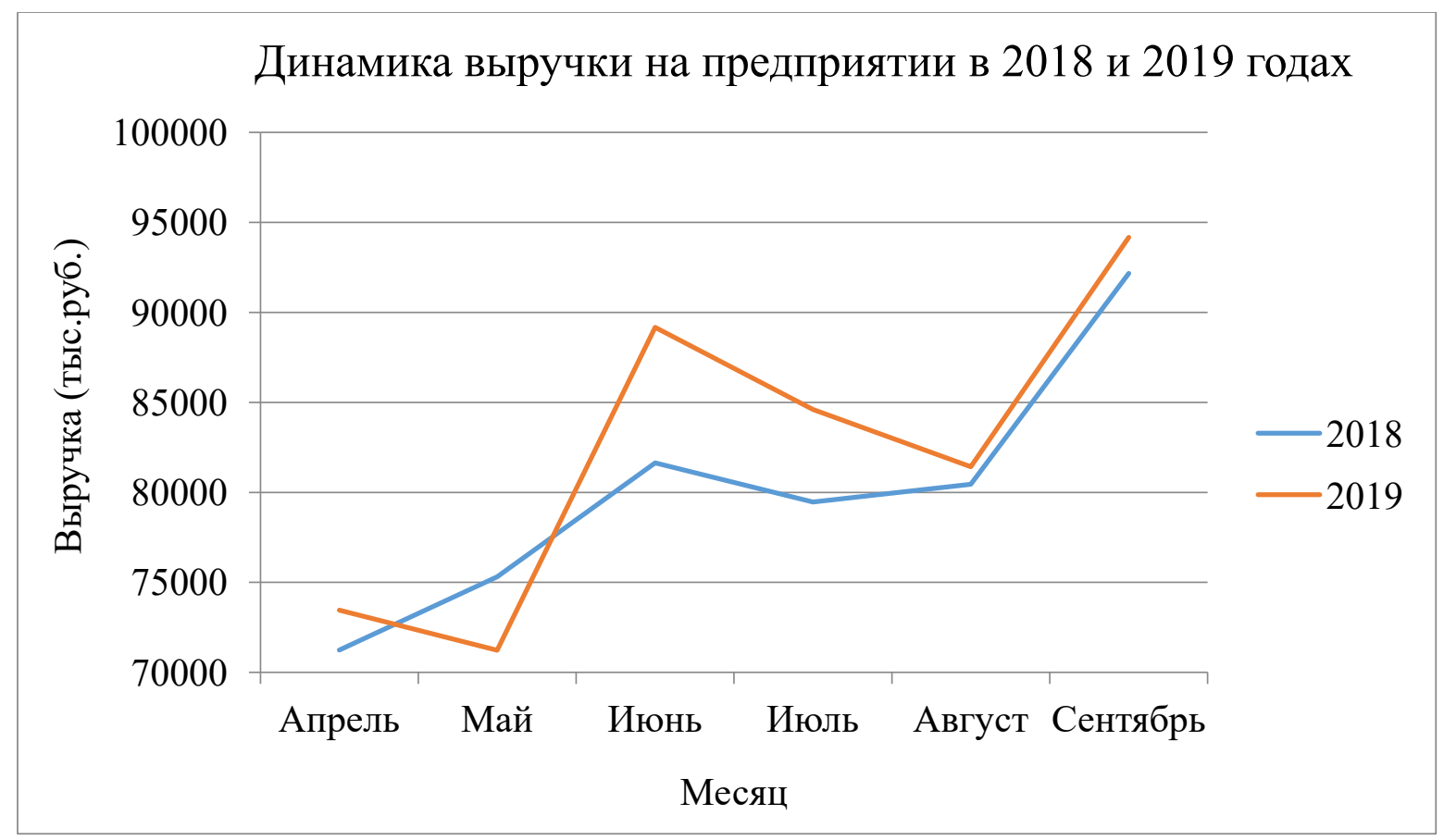

Рисунок 26. Динамика выручки на предприятии в 2018 и 2019 гг.

На графике наблюдается рост выручки предприятия в 2019 году. С апреля по сентябрь 2018 года выручка предприятия составила 480282 тысячи рублей, минимальное значение этого показателя 71245 тысяч рублей, максимальное - 92144 тысячи рублей. В 2019 году совокупный объем выручки за период составил 494061 тысячу рублей, что на 13779 тысяч рублей, или на 2,9 \%, больше, чем в 2018 году. Минимальное значение выручки в 2019 году 71234 тысячи рублей, а максимальное - 94167 тысяч рублей. После внедрения в мае 2019 года алгоритма распределения функциональных обязанностей сотрудников отдела продаж наблюдается рост выручки предприятия по сравнению с сопоставимым периодом предыдущего года. Приведем данные по изменению прибыли с апреля по сентябрь за 2018 и 2019 годы на рисунке 27. 


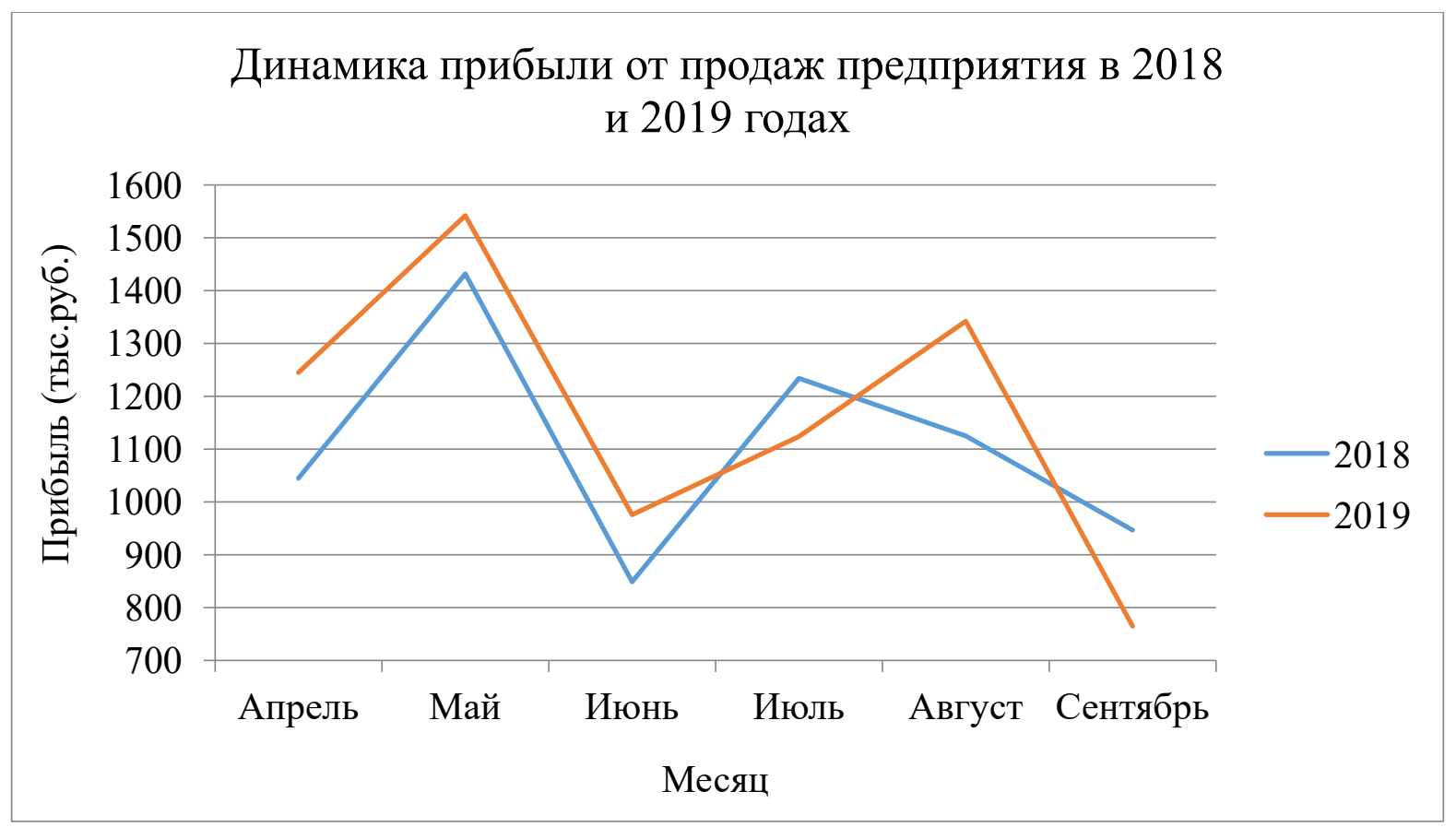

Рисунок 27. Динамика прибыли от продаж предприятия в 2018 и 2019 гг.

Прибыль от продаж с апреля по сентябрь 2018 года составила 6632 тысячи рублей, в то время как в 2019 году совокупный показатель прибыли составил 6994 тысячи рублей, что на 362 тысячи рублей, или на 5,5\%, больше, чем в 2018 году. Минимальное значение прибыли в 2018 году 849 тысяч рублей, максимальное - 1432 тысячи рублей. В 2019 году минимальное значение прибыли 765 тысяч рублей, а максимальное - 1542 тысячи рублей. После внедрения в мае 2019 года алгоритма наблюдается рост прибыли предприятия по сравнению с сопоставимым периодом предыдущего года. Скромная динамика прибыли по сравнению с динамикой выручки объясняется спецификой работы предприятия, поскольку отпускные цены формируются в зависимости от многих факторов и делается это на ежемесячной основе. Также стоит отметить, что в товарах более низкого ценового сегмента, как правило, показатели прибыли и рентабельности могут быть существенно выше. Рассмотрим, как повлияло внедрение алгоритма на рентабельность от продаж (ROS). Представим динамику рентабельности от продаж на рисунке 28. 


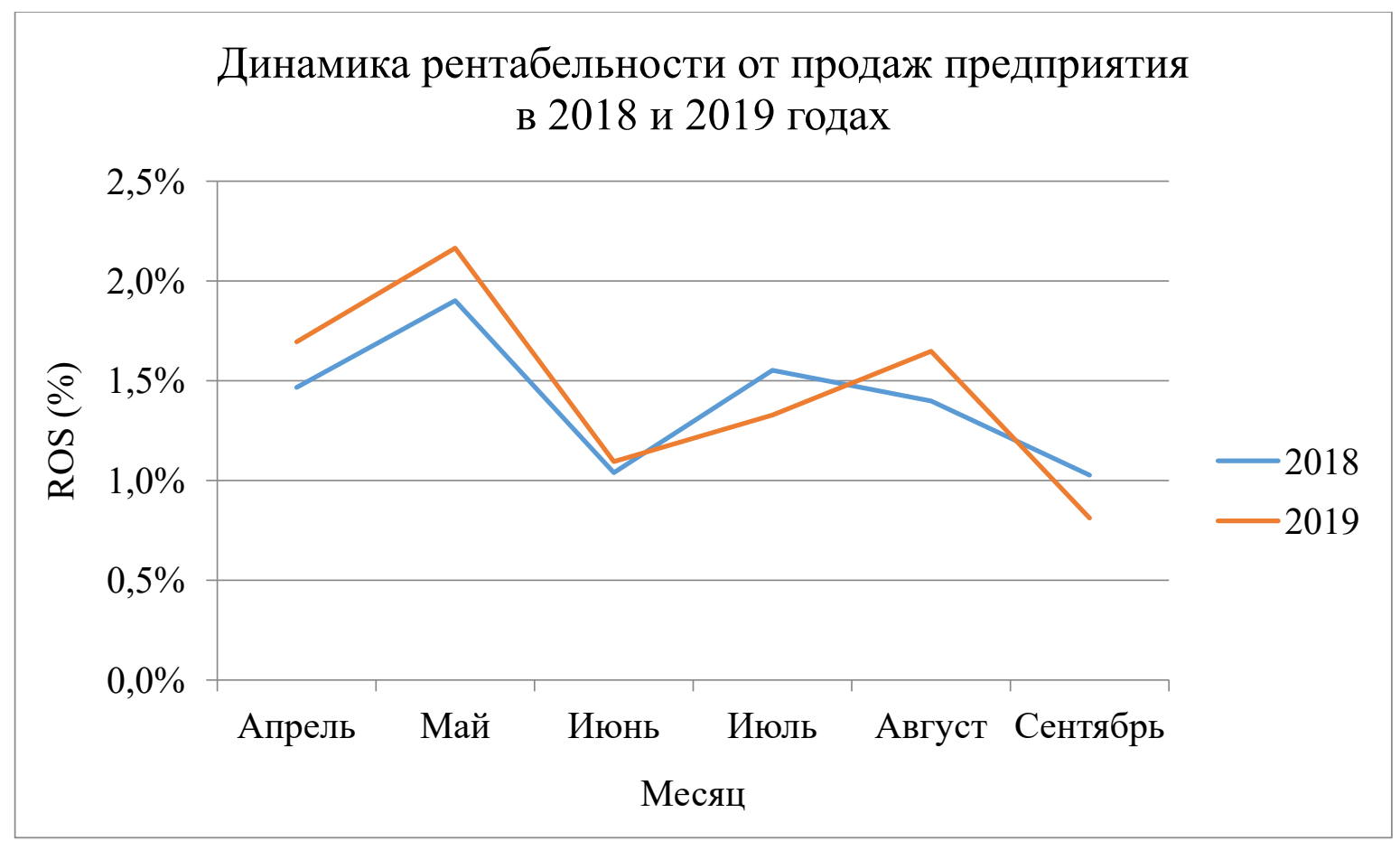

Рисунок 28. Динамика рентабельности от продаж предприятия в 2018 и 2019гг.

Рентабельность от основного вида деятельности предприятия в 2018 году в среднем составляла 1,4\%, при том что в 2019-м этот показатель вырос на 0,1 \% и составил 1,5 \%. При этом минимальное значение показателя рентабельности от основного вида деятельности предприятия в 2018 году составило 1 \%, а максимальное - 1,9 \%. В 2019 году минимальный показатель рентабельности продаж составил $0,8 \%$, а максимальный - 2,2 \%.

Рентабельность от продаж изменилась незначительно, данный факт можно тоже отчасти связать со спецификой деятельности предприятия. Одним из основных рычагов для стимуляции спроса в данном сегменте является гибкое ценообразование и наличие широкого спектра специальных продуктов и условий. Объем продаж в 2019 году вырос на 8 автомобилей, или на 6 \%, выручка выросла на 13779 тыс. руб., или на 2,9\%, в то время как прибыль увеличилась на 13779 тыс. руб., или на 2,9 \%, а рентабельность возросла на 0,1%. 
Далее рассмотрим, как изменилась доля рынка предприятия с апреля по сентябрь 2019 года по сравнению с сопоставимым периодом на рисунке 29.

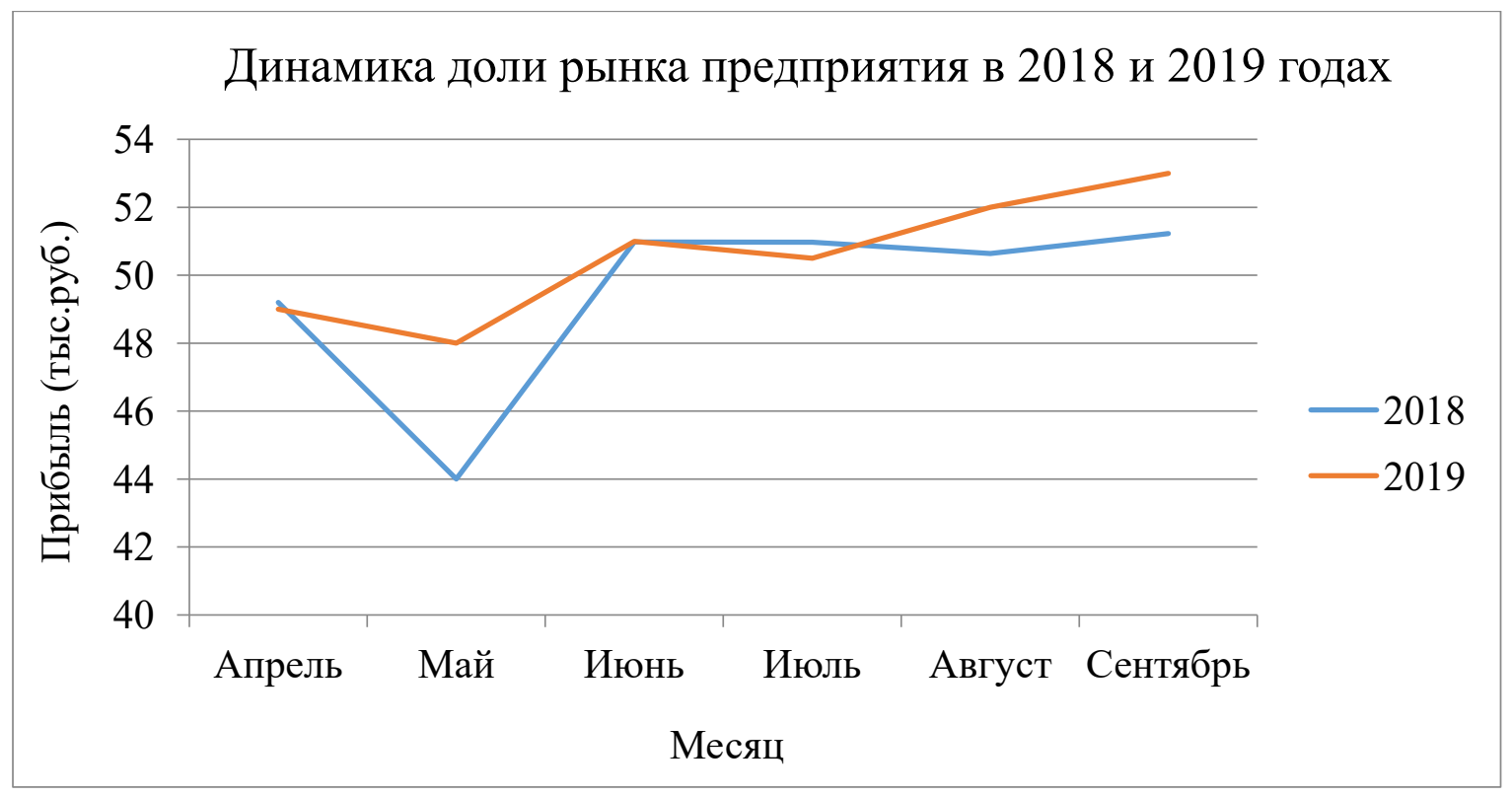

Рисунок 29. Динамика доли рынка предприятия в 2018 и 2019 гг.

Средний показатель доли рынка в 2018 году составил 49,5 \%, а в 2019 году на 1 \% больше - 50,5 \%. В таблице 36 представлены сводные экономические показатели деятельности предприятия.

Таблица 36.

Динамика экономических результатов деятельности предприятия

\begin{tabular}{|l|c|c|c|c|}
\hline \multicolumn{1}{|c|}{ Показатель } & 2018 год & 2019 год & $\begin{array}{c}\text { Изменения } \\
\text { абсолютные }\end{array}$ & $\begin{array}{c}\text { Изменения } \\
\text { относитель- } \\
\text { ные (\%) }\end{array}$ \\
\hline Объем продаж (шт.) & 136 & 142 & 8 & 6 \\
\hline Выручка (тыс. руб.) & 480282 & 494061 & 13779 & 2,9 \\
\hline Прибыль (тыс. руб.) & 6632 & 6994 & 362 & 5,5 \\
\hline $\begin{array}{l}\text { Рентабельность от } \\
\text { продаж (\%) }\end{array}$ & 1,4 & 1,5 & 0,1 & 0,1 \\
\hline Доля рынка (\%) & 49,5 & 50,5 & 1 & 1 \\
\hline
\end{tabular}


По результатам деятельности предприятия можно сделать вывод, что предложенный алгоритм оказал положительный экономический эффект: выручка предприятия увеличилась на 2,9 \%, прибыль на 5,5\%, доля рынка выросла на $1 \%$, а рентабельность выросла на $0,1 \%$. Тем не менее стоит еще раз заострить внимание и на специфике деятельности предприятия. В области продаж автомобилей сегмента выше среднего ценообразование на товар находится под влиянием руководства, которое оценивает не только рыночные тенденции, но и определенные бонусы, которые потом предприятие получает от производителя, и сотрудник отдела сбыта не формирует отпускные цены на товар. 


\section{ЗАКЛЮЧЕНИЕ}

Эмоциональный интеллект является одной из ключевых компетенций будущего. Эмоциональный интеллект влияет на степень эффективности коммуникации между людьми, так, люди с более высоким его уровнем легче и быстрее решают коммуникативные задачи. Это принципиально важно для предприятий малого и среднего бизнеса в сфере торговли, поскольку основной объем выручки формируется за счет продажи товаров и услуг.

В ходе исследования были получены следующие результаты:

- изучен генезис понятия эмоциональный интеллект и рассмотрены основные модели и способы измерения эмоционального интеллекта в отечественной и зарубежной литературе. С целью анализа влияния эмоционального интеллекта работников был инициирован социологический опрос, в котором исследовались показатели эффективности трудовой деятельности работников отдела сбыта на предприятии и эмоциональный интеллект (уровень общего эмоционального интеллекта и каждой из его компонент). После проведения анализа с использованием статистических методов было установлено, что гипотеза о влиянии эмоционального интеллекта на результаты деятельности работников на предприятии в сфере торговли легковыми автомобилями подтвердилась;

- доказана взаимосвязь динамики эмоционального интеллекта по отделу сбыта на предприятии и результатов хозяйственной деятельности предприятия, что свидетельствует о том, что с ростом среднего значения эмоционального интеллекта по отделу в целом экономические результаты растут. В связи с этим можно сделать вывод о том, что эмоциональный интеллект в структурных подразделениях предприятия, которые занимаются сбытом продукции, играет одну из ключевых ролей. Данное положение можно использовать 
для развития исследований о месте и роли эмоционального интеллекта в экономике на предприятиях различных масштабов и отраслей;

- предложены 4 вида предприятий, по каждому из которых были представлены показатели, согласно которым можно определить место эмоционального интеллекта в деятельности работника и дать оценку эффективности результатов труда. Предложенные показатели можно внедрить в ССП для сбытового отдела для оперативного и стратегического управления отделом сбыта для целей повышения результатов экономической деятельности предприятия. Кроме того, были выделены 4 типа сотрудников отдела сбыта в зависимости от уровня эмоционального интеллекта и основного показателя результативности работы таких сотрудников - коэффициента выполнения индивидуальных планов продаж, который является ключевым в формировании одного из базовых результатов экономической деятельности предприятия - объема продаж. В зависимости от типа сотрудника были предложены функциональные обязанности и методики постановки оперативных целей, которые влияют на экономические итоги работы предприятия. Вследствие чего были предложены 4 алгоритма: для каждого вида предприятия и каждого типа сотрудника на этом предприятии. Таким образом, был предложен методический подход к развитию предприятия с учетом уровня эмоционального интеллекта сотрудников;

- проведена апробация на предприятии малого бизнеса, результаты которой показали положительный экономический эффект, с учетом всех ограничений, в рамках которых предприятие реализует хозяйственную деятельность. Объем продаж прирос на $6 \%$, выручка предприятия увеличилась на 2,9\%, прибыль - на 5,5\%, доля рынка выросла на 1 \%, а рентабельность выросла на 0,1 \% по сравнению с базовым периодом.

Учитывая долю рынка продаж товаров и услуг в реальном секторе экономики в России, рекомендуется для обеспечения кон- 
курентоспособности предприятия и реализации его экономических целей в долгосрочной перспективе при анализе и развитии человеческого капитала принимать во внимание важность одной из ключевых компетенций, которая обеспечивает конструктивную, положительную коммуникацию с потребителями, равно как и шанс предприятия увеличить итоговые результаты экономической деятельности, - эмоциональный интеллект. 


\section{СПИСОК ИСПОЛЬЗОВАННЫХ ИСТОЧНИКОВ}

1. Библия. Книги Ветхого Завета. - М.: Рос. библейское о-во, 2014. - 292 c. - ISBN 978-5-85524-312-3.

2. Андреева И.Н. Эмоциональный интеллект как феномен современной психологии / И.Н. Андреева. - Новополоцк: ПГУ, 2011. 388 c. - ISBN 978-985-531-260-5.

3. Шкуратов В.А. Историческая психология / В.А. Шкуратов. М.: Смысл, 1997. - 505 с. - ISBN 978-5-91375-090-7.

4. Боялись так же и того же: как изменились страхи с античных времен и почему тревожность так трудно контролировать // Теории и практики. Электронный журнал. - URL: https://theoryandpractice.ru/ posts/17180-boyalis-tak-zhe-i-togo-zhe-kak-izmenilis-strakhi-s-antichnykhvremen-i-pochemu-trevozhnost-tak-trudno-kontrolirovat (дата обращения: 15.05.2019).

5. Лафренье П. Эмоциональное развитие детей и подростков / П. Лафренье - СПб.: Прайм-Еврознак, 2004. - 256 с. - ISBN 5-93878124-8.

6. Бхагаван Ш.Р. Библия Раджниша / Ш.Р. Бхагаван. В Т. 3, ч. 1. М.: Либрис, 1994. - 287 с. - ISBN 978-00-1465625-0.

7. Холмогорова А.Б., Гаранян Н.Г. Культура, эмоции и психическое здоровье / А.Б. Холмогорова. // Вопросы психологии. - 1999. № 2. - C. 61-73. - URL: http://www.voppsy.ru/issues/1999/992/ 992061.htm (дата обращения: 16.12.2019).

8. Яковлева Е.Л. Эмоциональные механизмы личностного и творческого развития / Е.Л. Яковлева // Вопросы психологии. - 1997. № 4. - C. 20-27. - URL: http://www.voppsy.ru/issues/1997/974/ 974020.htm (дата обращения: 16.12.2019). 
9. Дегтярев А.В. «Эмоциональный интеллект»: становление понятия в психологии /А.В. Дегтярев // Психологическая наука и образование. - 2012. - № 2 - С. 1-13.

10. Mayer J. D. A field guide to emotional intelligence / Ciarrochi J.P., Forgas J. P., Mayer J.D. - Philadelphia, P.A. : Psychology Press. - 2001. - P. 3-24.

11. Холодная М.А. Психология интеллекта: парадоксы исследования / М.А. Холодная. - М.: Изд-во «Барс», 1997. - 392 с. ISBN 978-5-534-07365-2.

12. Ekman P. Darwin and facial expression: Century of research in review. - N.Y.: Academic Press, 1973. - 294 p. - ISBN 978-1883536886.

13. Майер Г. Психология эмоционального мышления / Г. Майер. - М.: Изд-во МГУ, 1981. - С. 123-129.

14. Лобанов А.П., Коптева С.И., Ткачук О.А. Интеллект и личностный рост: учеб. пособие / А.П. Лобанов. - Минск: БГПУ, 2002. $128 \mathrm{c}$.

15. Дружинин В.Н. Психология общих способностей / В.Н. Дружинин. - СПб.: «Питер», 2007 - 368 с. - ISBN 978-5-91180111-3.

16. Bandura A. Self-efficacy: Toward a unifying theory of behavioral change / A. Bandura. - Stanford University: Psychol. Rev, 1977. № 84. - P. 191-215.

17. Wechsler D. The measurement and appraisal of adult intelligence. / D. Wechsler. - Baltimore, MD: The Williams \& Wilkins Company, 1958. $-297 \mathrm{p}$.

18. Bar-On R. Development of the Ваг-On EQ-I: A measure of emotional intelligence. Paper presented at 105th Annual Convention of American Psychological Association. Chicago, 1997. 
19. Эллис А. Гуманистическая психотерапия: рациональноэмоциональный подход. / А. Эллис. - М.: ЭКСМО-Пресс, 2002. 272 c. - ISBN 5-04-010213-5.

20. Van Ghent D. The English novel: Form and function. / D. Van Ghent. - N.Y.: Harper and Row, 1953. - 485 p. - ISBN 978-0061310508.

21. Bower G.H., Cohen P.R. Emotional influences in memory and thinking: Data and theory / Clark M.S., Fiske S.T. // Affect and cognition. Hillsdale, NJ: Erlbaum, 1982. - P. 291-331.

22. Изард И. Эмоции человека / И. Изард. - М.: Изд-во Моск. ун-та, 1980. - 440 с.

23. Айзенк М. Психология: комплексный подход / М. Айзенка. Мн.: Новое знание, 2002. - 829 с. - ISBN 978-9856516514.

24. Орме Г. Эмоциональное мышление как инструмент достижения успеха. / Г. Орме. - М.: «КСП+», 2003. - 272 с. - ISBN 978-589692-088-5.

25. Payne W.L. A study of emotion: Developing emotional intelligence; Self-integration; relating to fear, pain and desire. - EQI. - URL: https://eqi.org/payne.htm (дата обращения 01.12.2019).

26. Mayer J.D., Salovey P. Personality moderates the effects of affect on cognition. / J.D. Mayer. - Toronto: Hogrete, 1988. - P. 87-99.

27. Mayer J.D., Salovey P. The intelligence of emotional intelligence / J.D. Mayer // Intelligence. - 1993. - № 17. - P. 433-442.

28. Горскова Г.Г. Введение понятия эмоционального интеллекта в психологическую культуру / Г.Г. Горскова // Ананьевские чтения: тез. научн.-практ. конф. СПб. - 1999. - С. 45-48.

29. Mayer J.D. Emotion, intelligence, emotional intelligence // Forgas J.P. (ed.). The handbook of affect and social cognition. - Mahwah, NJ: Lawrence Erlbaum, 2000. - P. 410-431. 
30. Bandeji N. Emotions in economic action and interaction / N. Bandeji // Theory and Society, - 2009. - № 38. - URL: https://link. springer.com/article/10.1007/s11186-009-9088-2 (дата обращения: 21.06.2020).

31. Выготский Л.С. Мышление и речь / Л.С. Выготский. - М.: Учпедгиз, 1934. - $321 \mathrm{c.}$

32. Рубинштейн С.Л. Проблемы общей психологии / С.Л. Рубинштейн. - М.: Педагогика, 1973. - 416 с.

33. Рубинштейн С.Л. Основы общей психологии: В 2 т. Т. 2. / С.Л. Рубинштейн. - М.: Педагогика, 1989. - 382 с. - ISBN 5-71550180-6.

34. Зейгарник Б В. Патопсихология / Б.В. Зейгарник. - М.: Издво МГУ, 1986. - 287 с.

35. Тихомиров О.К. Психология мышления / О.К. Тихомиров. М.: Изд-во МГУ, 1984. - 272 с.

36. Брушлинский А.В. Психология субъекта в изменяющемся обществе / А.В. Брушлинский // Психологический журнал. - 1997. № 2. - C. 18-32.

37. Хьелл Л., Зиглер Д. Теории личности / Л. Хьелл. - СПб.: Питер, 1999. - 672 с. - ISBN 5-04-002853-9.

38. Ларина А.Т. Эмоциональный интеллект / А.Т. Ларина // АНИ: педагогика и психология. - 2016. - № 3. - С. 275-278.

39. Гарскова Г. Г. Введение понятия «эмоциональный интеллект» в психологическую теорию / Г. Г. Гарскова // Ананьевские чтения: тез. науч.- практ. конф.; редкол.: А. А. Крылов. - СПб. : Издво Санкт-Петерб. ун-та, 1999. - С. 25-26.

40. Ильин Е.П. Эмоции и чувства : учеб. пособие для студ. вузов / Е.П. Ильин. - СПб.: Питер, 2001. - 752 с. - ISBN 978-5-4461$1070-4$. 
41. Люсин Д.В. Социальный интеллект: Теория, измерение, исследования / Д.В. Люсин, Д.В. Ушакова. - М.: Ин-т психологии PAH, 2004. - 176 c. - ISBN 5-9270-0058-4.

42. Манойлова М.А. Акмеологическое развитие эмоционального интеллекта учителей и учащихся: учеб. пособ. для студ. вузов / М.А. Манойлова. - Псков: ПГПИ, 2004. - 140 с. - ISBN 5-87854-330-3.

43. Карпов А.В. Психология эмоционального интеллекта: теория, диагностика, практика / А.В. Карпов, А.С. Петровская. - Ярославль: ЯрГУ, 2008. - 344 с. - ISBN 978-5-8397-0638-5.

44. Хлевная Е.А. Роль эмоционального интеллекта в эффективности деятельности: на примере руководителей: спец. 19.00.01 «Психология»: дис. канд. псих. наук / Хлевная Елена Антольевна; ЯрГУ им. П.Г. Демидова. - Ярославль, 2012. - 212 с.

45. Перепёлкин Н.А. Развитие событийного маркетинга в российских компаниях автореферат кандидатской диссертации: спец. 08.00.05 «Экономика»: автореф. дис. канд. экон. наук / Перепёлкин Николай Александрович; РГГУ. - Москва, 2016. - 28 с.

46. Cherniss C., Extein M. Emotional Intelligence: What Does the Research Really Indicate? / C. Cherniss, M. Extain // The Educational Psychologist. - 2006. - № 41(4). - P. 239-245.

47. Mayer J.D. Perceiving affective content in ambiguous visual stimuli: a component of emotional intelligence / J.D. Mayer, M. Di Paolo, P. Salovey // Journal of Personality Assessment. - 1990. - Vol. 54, № 3, 4. P. 772-781.

48. Mayer J.D. What is emotional intelligence? / J.D. Mayer, P. Salovey // P. Salovey, D. Sluyter (Eds.), Emotional development and emotional intelligence: Educational implications. - New York: Basic, 1997. - P. 3-31.

49. Izard C.E. Emotional intelligence or adaptive emotions? / C.E. Izard // Emotion. - 2001. - P. 249 -257. 
50. Erez A. The influence of positive affect on the components of expectancy motivation / A. Erez, A.M. Isen // Journal of Applied Psychology. - 2002. - № 87. - P. 1055-1067.

51. Полянова Л.М. Использование моделей эмоционального интеллекта в оценке управленческой деятельности / Л.М. Полянова // Вестник РУДН, серия «Социология». - 2014. - № 2. - С. 161-173.

52. Люсин Д.В. Новая методика для измерения эмоционального интеллекта: опросник ЭмИн / Д.В. Люсин // Психологическая диагностика. - 2006. - № 4. - С. 3-22.

53. Каплан Р. Сбалансированная система показателей. От стратегии к действию. - М.: ЗАО «Олимп-Бизнес», 2003. - 304 с. ISBN 978-5-9693-0358-4.

54. Голубицкий Б.И., Васильев Д.Е. Система сбалансированных показателей Каплана-Нортона: международный опыт для отечественных компаний. / Б.И. Голубицкий, Д.Е. Васильев // Экспортная база России. Российский внешнеэкономический вестник. - 2009. № 10. - C. $44-51$.

55. Хлевная Е.А. Взаимосвязь эмоционального интеллекта руководителей и экономической эффективности организации. / Е.А. Хлевная // Экономическая психология: актуальные теоретические и прикладные проблемы. - Иркутск: БГУ, 2011. - С. 212-221.

56. Kumar V., Sunder S., Leone R. Measuring and managing a salesperson's future value to the firm. / V. Kumar // Journal of Marketing Research. - 2014. - № 51(5). - P. 591-608.

57. Little B. Virtual value soars for sales-related skills / B. Little // Industrial and Commercial Training. - 2014. - № 46(5). - P. 265-269.

58. Frino M.G., Desiderio K.P. The role of demographics as predictors of successful performance of sales professionals in business-tobusiness sales organizations / M.G. Frino // Performance Improvement Quarterly. - 2013. - № 25(4). - P. 7-21. 
59. Росконгресс. Эмоциональный интеллект и 4-я промышленная революция. 2018 - URL: http://photo.roscongress.org/ru/49/photos/list? PhotosContainerId=1208\&OnlyVisible $=$ True\&OrderDirection=Asc $\quad$ (дата обращения: 21.08.2019).

60. Социальное предпринимательство в России // Блоги компаний. - URL: https://vc.ru/finance/60598-socialnoe-predprinimatelstvo-vrossii (дата обращения: 26.09.2019).

61. Ф3 «О развитии малого и среднего предпринимательства в Российской Федерации» от 24.07.2007 № 209-Ф3 // Консультант. URL: http://www.consultant.ru/document/cons_doc_LAW_52144/ (дата обращения: 12.10.2019).

62. Аналитическое агентство ABTOCTAT // Автостат. - URL: https://www.autostat.ru/tags/mark_model/59/249/3/ (дата обращения: 12.12.2019).

63. Россия в цифрах. Федеральная служба государственной статистики 2018. - URL: https:/www.gks.ru/free_doc/doc_2018/ rusfig/rus18.pdf (дата обращения 13.12.2019).

64. Авторынок ниже нуля. Резкое падение продаж предвещает депрессию // Коммерсант. - URL: https:/www.kommersant.ru/ doc/4154387 (дата обращения: 13.12.2019).

65. Ф3 «О развитии малого и среднего предпринимательства в Российской Федерации» от 24.07.2007 № 209-Ф3 // Консультант. URL: http://www.consultant.ru/document/cons_doc_LAW_52144/ (дата обращения: 12.10.2019).

66. Постановление Правительства Российской Федерации от 13 июля 2015 г. № 702 г. Москва «О предельных значениях выручки от реализации товаров (работ, услуг) для каждой категории субъектов малого и среднего предпринимательства»// Консультант. URL: http://www.consultant.ru/law/hotdocs/43689.html/ (дата обращения: 24.12.2019). 
67. Трубачева С.И. Показатели оценки эффективности маркетинга / С.И. Трубачева // Вестник Волжского Университета им. Татищева. - 2008. - URL: https://cyberleninka.ru/article/n/pokazateliotsenki-effektivnosti-marketinga/viewer (дата обращения 11.11.2019).

68. Талер Р. Новая поведенческая экономика. Почему люди нарушают правила традиционной экономики / Р. Талер. - М.: Эксмо, 2018. - 384 c. - ISBN: 978-5-04-091150-9.

69. Власов А.В. Поведенческая экономика как новая область исследования в экономической науке / А.В. Власов // Модели, системы, сети в экономике, технике, природе и обществе. - 2017. URL: https://cyberleninka.ru/article/n/povedencheskaya-ekonomika-kaknovaya-oblast-issledovaniya-v-ekonomicheskoy-nauke/viewer (дата обращения: 12.10.2019).

70. Jan-Christoph Köstring, S. Middleton, T. Möller, A. Padhi, A. Tschiesner. The new realities of premium mobility / S. Middleton // McKinsey Center for Future Mobility. - 2019. - URL: https://www. mckinsey.com/industries/automotive-and-assembly/our-insights/ the-newrealities-of-premium-mobility (дата обращения: 28.12.2019).

71. Романенко Е.В. Влияние конверсии на эффективность интернет-магазина / Е.В. Романенко // Инновационная наука. - 2016. URL: https://cyberleninka.ru/article/n/vliyanie-konversii-na-effektivnostinternet-magazina (дата обращения: 25.10.2019).

72. Куропаткина А.А. Зарубежные и отечественные подходы к понимаю эмоционального интеллекта / А.А. Куропаткина // Вопросы педагогики. - 2019. - № 9(2). - С. 50-55.

73. Гоулман Д. Эмоциональный интеллект. Почему он может значить больше, чем IQ. - 4-е изд. - М.: Манн, Иванов и Фербер, 2016. - 544 c. - ISBN 978-5-17-050409-1. 
74. Чиннова А.С. Структура эмоционального интеллекта участников и эффективность переговорного процесса / А.С. Чиннова // Психологические науки: теория и практика: материалы междунар. науч. конф. - г. Москва, февраль 2012 г. - М.: Буки-Веди, 2012. C. 63-66.

75. Фатрелл Ч. Управление продажами / Ч. Фатрелл. - СПб.: Издат. дом «Нева», 2004. - 640 с. - ISBN 5-7654-3246-8.

76. Спиро Р.Л., Стэнтон У. Дж. Управление продажами / Р.Л. Спиро. - М.: Издат. дом Гребенникова, 2004. - 704 с. ISBN 978-5-93890-021-9.

77. Сотникова Т.В. Отдел продаж под «ключ». Проект, организация, управление / Т.В. Сотникова. - СПб.: Питер, 2009. - 400 с. ISBN 978-5-388-00455-0.

78. Петров К.Н. Управление отделом продаж. Планирование. Организация. Контроль / К.Н. Петров. - М.: Вильямс, 2011. - 336 с. ISBN 978-5-8459-2138-3.

79. Олейник К. Все об управлении продажами / К. Олейник. М.: Альпина Паблишерс, 2011. - 330 с. - ISBN 9785961409772.

80. Ланкастер Дж. Продажа и управление сбытом / Дж. Ланкастер, Д. Джоббер. - Минск: Амалфея, 1999. - 384 с. - ISBN 5-23800465-6.

81. Котлер Ф. Основы маркетинга. Краткий курс / Ф. Котлер. М.: Издательский дом «Вильямс», 2005. - 656 с. - ISBN 9785845917331.

82. Баркан Д.И. Управление продажами / Д.И. Баркан. - СПб.: издат. дом Санкт-Петербургского гос. ун-та, 2007. - 908 с. - ISBN 978-5-9924-0003-8.

83. Вертоградов В. Управление продажами. - 2-е изд. / В. Вертоградов. - СПб.: Питер, 2011. - 236 с. - ISBN 9785948480572. 
84. Рамперсад Х., Туоминен К. Универсальная система показателей для оценки личной и корпоративной эффективности / Х. Рамперсад, К. Туоминен. - М.: Альпина Бизнес Букс, 2006. - 152 с. ISBN 5-9614-0301-7.

85. Суханова И.М., Скриптунова Е.А. Комплексная оценка менеджеров по продажам по количественным и качественным показателям / И.М. Суханова, Е.А. Скриптунова // Управление сбытом. 2007. - № 6. - URL: http://www.axima-consult.ru/stati-komplocen.html (дата обращения: 02.01.2020).

86. Shone A., Parry B. Successful event management: a practical handbook. / Anton Shone, Bryn Parry - Cengage Learning EMEA, 2004. $242 \mathrm{p}$.

87. Damster G., Tassiopoulos D. Event Management: A Professional and Developmental Approach / G. Damster, D.Tassiopoulos - Juta Academic: Lansdowne, 2007. - 440 p.

88. Albarran A.B. Media Economics. Ungerstanding Markets, Industries and Concept. / A.B. Albarranю - Iowa: Iowa State Press, 2002. $228 \mathrm{p}$.

89. Alexander A. Media Economics. Theory and Practice. / Edited by A. Alexander. - New Jersey: Lawrence Erlbaum Associates Publishers, 2004. $-312 \mathrm{p}$.

90. Harris J., Corporate Excellence: How to Maximize Long-term Productivity \& Profits by Aligning Purpose, Culture \& People / Jim Harris. - Pensacola FL: AGR, 2005. - 128 p.

91. Agnihotri R., Krush M., Singh R.K. Understanding the mechanisms linking interpersonal traits to pro-social behaviors among salespeople: Lessons from India / R. Agnihotri // Journal of Business \& Industrial Marketing. - 2012. - № 27(3). - P. 211-227. 
92. Ahuja A. Emotional intelligence as a predictor of performance in insurance sector. / A. Ahuja // Asia Pacific Journal of Management Research and Innovation. - 2012. - № 7(2). - P. 121-135.

93. Borg S.W., Johnston W.J. The IPS-EQ Model: Interpersonal skills and emotional intelligence in a sales process / S. W. Borg // Journal of Personal Selling and Sales Management. - 2012. - № 33(1). - P. 39-52.

94. Boyatzis R.E., Good D., Massa R. Emotional, social, and cognitive intelligence and personality as predictors of sales leadership performance / R. Boyatzis // Journal of Leadership \& Organizational Studies. 2012. - № 19(2). - P. 191-201.

95. Brown C. The effects of emotional intelligence (EI) and leadership style on sales performance. / C. Brown // Economic Insights Trends \& Challenges. 2013. - № 66(3). - P. 1-14.

96. Chaudhry A., Usman A. An investigation of the relationship between employees' emotional intelligence and performance. / A. Chaudgry // African Journal of Business Management. - 2011. - № 5(9). - P. 35563562.

97. Cheng T., Huang G., Lee C., Ren X. Longitudinal effects of job insecurity on employee outcomes: The moderating role of emotional intelligence and the leader-member exchange / T. Cheng // Asia Pacific Journal of Management. - 2011. - № 29(3). - P. 709-728.

98. De La Cruz H., D’Urso P.A., Ellison A. The relationship between emotional intelligence and successful sales performance in the Puerto Rico market / H. De La Cruz // Journal of Psychological Issues in Organizational Culture. - 2014. - № 5(3). - P. 6-39.

99. Di Fabio A., Saklofske D.H. Promoting individual resources: The challenge of trait emotional intelligence / A. Di Fabio // Personality and Individual Differences. - 2014. - № 65(1). - P. 19-23. 
100. Giorgi G., Mancuso S., Fiz Perez F. J. / G. Giorgi // Organizational emotional intelligence and top selling. Europe's Journal of Psychology. - 2014. - № 10(4). - P. 712-725.

101. Hughes D., Bon J., Rapp A. Gaining and leveraging customerbased competitive intelligence: the pivotal role of social capital and salesperson adaptive selling skills / D. Hughes // Journal of the Academy of Marketing Science. - 2014. - № 41(1). - P. 91-110.

102. Joseph D.L., Jin J., Newman D.A., O'Boyle E.H. Why does self-reported emotional intelligence predict job performance? A metaanalytic investigation of mixed EI / D.L. Joseph // Journal of Applied Psychology. - 2014. - № 100(2). - P. 298-342.

103. Megowan G. A correlation study of emotional intelligence and behavioral style of bio-pharmaceutical industry district sales managers / G. Megowan. - Tennessee : Walden University, 2012. - 141 p.

104. Prentice C., King B.M. Emotional intelligence in a hierarchical relationship: Evidence for frontline service personnel / C. Prentice, B.M. King. // Services Marketing Quarterly. - 2011. - № 33(1). - P. 34-48.

105. Roy R., Chaturvedi S. Job experience and age as determinants of emotional intelligence: An exploratory study of print media employees. / R. Roy, S. Chaturvedi // BVIMR Management Edge Journal. - 2011. № 4(2). - P. 68-76. 


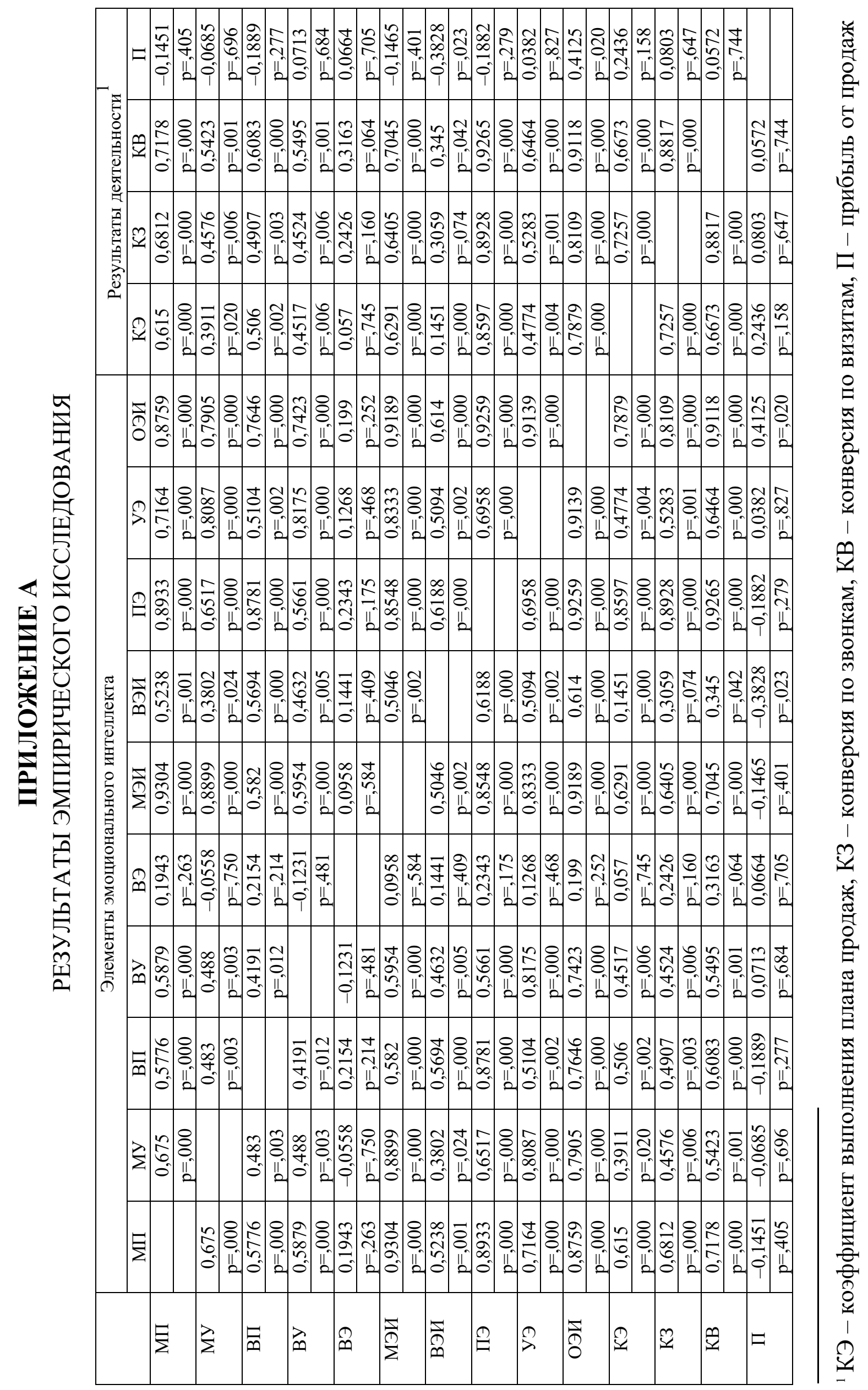




\section{ПРИЛОЖЕНИЕ Б}

Вам предлагается заполнить опросник, который состоит из 46 утверждений. Читайте внимательно каждое утверждение и ставьте крестик (или галочку) в той графе, которая лучше всего отражает Ваше мнение.

\begin{tabular}{|c|c|c|c|c|c|c|c|c|c|}
\hline № & $\begin{array}{c}\text { Со- } \\
\text { всем } \\
\text { не со- } \\
\text { гласен }\end{array}$ & $\begin{array}{l}\text { Скорее } \\
\text { не со- } \\
\text { гласен }\end{array}$ & $\begin{array}{c}\text { Скорее } \\
\text { согла- } \\
\text { сен }\end{array}$ & $\begin{array}{c}\text { Полно- } \\
\text { стью со- } \\
\text { гласен }\end{array}$ & № & $\begin{array}{c}\text { Совсем } \\
\text { не со- } \\
\text { гласен }\end{array}$ & $\begin{array}{c}\text { Скорее } \\
\text { не со- } \\
\text { гласен }\end{array}$ & $\begin{array}{c}\text { Скорее } \\
\text { согла- } \\
\text { сен }\end{array}$ & $\begin{array}{c}\text { Полно- } \\
\text { стью со- } \\
\text { гласен }\end{array}$ \\
\hline 1 & & & & & 24 & & & & \\
\hline 2 & & & & & 25 & & & & \\
\hline 3 & & & & & 26 & & & & \\
\hline 4 & & & & & 27 & & & & \\
\hline 5 & & & & & 28 & & & & \\
\hline 6 & & & & & 29 & & & & \\
\hline 7 & & & & & 30 & & & & \\
\hline 8 & & & & & 31 & & & & \\
\hline 9 & & & & & 32 & & & & \\
\hline 10 & & & & & 33 & & & & \\
\hline 11 & & & & & 34 & & & & \\
\hline 12 & & & & & 35 & & & & \\
\hline 13 & & & & & 36 & & & & \\
\hline 14 & & & & & 37 & & & & \\
\hline 15 & & & & & 38 & & & & \\
\hline 16 & & & & & 39 & & & & \\
\hline 17 & & & & & 40 & & & & \\
\hline 18 & & & & & 41 & & & & \\
\hline 19 & & & & & 42 & & & & \\
\hline 20 & & & & & 43 & & & & \\
\hline 21 & & & & & 44 & & & & \\
\hline 22 & & & & & 45 & & & & \\
\hline 23 & & & & & 46 & & & & \\
\hline
\end{tabular}




\section{Опросник:}

1. Я замечаю, когда близкий человек переживает, даже если он (она) пытается это скрыть

2. Если человек на меня обижается, я не знаю, как восстановить с ним хорошие отношения

3. Мне легко догадаться о чувствах человека по выражению его лица

4. Я хорошо знаю, чем заняться, чтобы улучшить себе настроение

5. У меня обычно не получается повлиять на эмоциональное состояние своего собеседника

6. Когда я раздражаюсь, то не могу сдержаться, и говорю всё, что думаю

7. Я хорошо понимаю, почему мне нравятся или не нравятся те или иные люди

8. Я не сразу замечаю, когда начинаю злиться

9. Я умею улучшить настроение окружающих

10. Если я увлекаюсь разговором, то говорю слишком громко и активно жестикулирую

11. Я понимаю душевное состояние некоторых людей без слов

12. В экстремальной ситуации я не могу усилием воли взять себя в руки

13. Я легко понимаю мимику и жесты других людей

14. Когда я злюсь, я знаю, почему

15. Я знаю, как ободрить человека, находящегося в тяжелой ситуации 
16. Окружающие считают меня слишком эмоциональным человеком

17. Я способен успокоить близких, когда они находятся в напряжённом состоянии

18. Мне бывает трудно описать, что я чувствую по отношению к другим

19. Если я смущаюсь при общении с незнакомыми людьми, то могу это скрыть

20. Глядя на человека, я легко могу понять его эмоциональное состояние

21. Я контролирую выражение чувств на своем лице

22. Бывает, что я не понимаю, почему испытываю то или иное чувство

23. В критических ситуациях я умею контролировать выражение своих эмоций

24. Если надо, я могу разозлить человека

25. Когда я испытываю положительные эмоции, я знаю, как поддержать это состояние

26. Как правило, я понимаю, какую эмоцию испытываю

27. Если собеседник пытается скрыть свои эмоции, я сразу чувствую это

28. Я знаю, как успокоиться, если я разозлился

29. Можно определить, что чувствует человек, просто прислушиваясь к звучанию его голоса

30. Я не умею управлять эмоциями других людей

31. Мне трудно отличить чувство вины от чувства стыда 
32. Я умею точно угадывать, что чувствуют мои знакомые

33. Мне трудно справляться с плохим настроением

34. Если внимательно следить за выражением лица человека, то можно понять, какие эмоции он скрывает

35. Я не нахожу слов, чтобы описать свои чувства друзьям

36. Мне удаётся поддержать людей, которые делятся со мной своими переживаниями

37. Я умею контролировать свои эмоции

38. Если мой собеседник начинает раздражаться, я подчас замечаю это слишком поздно

39. По интонациям моего голоса легко догадаться о том, что я чувствую

40. Если близкий человек плачет, я теряюсь

41. Мне бывает весело или грустно без всякой причины

42. Мне трудно предвидеть смену настроения у окружающих меня людей

43. Я не умею преодолевать страх

44. Бывает, что я хочу поддержать человека, а он этого не чувствует, не понимает

45. У меня бывают чувства, которые я не могу точно определить

46. Я не понимаю, почему некоторые люди на меня обижаются 


\section{ПРИЛОЖЕНИЕ В}

\section{ИНТЕРПРЕТАЦИЯ РЕЗУЛЬТАТОВ ОПРОСНИКА Д.В. ЛЮСИНА}

\begin{tabular}{|c|c|c|c|c|c|c|}
\hline № & Утверждение & $\begin{array}{l}\text { Совсем } \\
\text { не со- } \\
\text { гласен }\end{array}$ & $\begin{array}{l}\text { Скорее } \\
\text { не со- } \\
\text { гласен }\end{array}$ & $\begin{array}{l}\text { Скорее } \\
\text { согласен }\end{array}$ & $\begin{array}{l}\text { Полностью } \\
\text { согласен }\end{array}$ & Шкала \\
\hline 1. & $\begin{array}{l}\text { Я замечаю, когда близкий человек пережи- } \\
\text { вает, даже если он (она) пытается это } \\
\text { скрыть }\end{array}$ & 0 & 1 & 2 & 3 & МП \\
\hline 2. & $\begin{array}{l}\text { Если человек на меня обижается, я не знаю, } \\
\text { как восстановить с ним хорошие отношения }\end{array}$ & 3 & 2 & 1 & 0 & МУ \\
\hline 3. & $\begin{array}{l}\text { Мне легко догадаться о чувствах человека } \\
\text { по выражению его лица }\end{array}$ & 0 & 1 & 2 & 3 & МП \\
\hline 4. & $\begin{array}{l}\text { Я хорошо знаю, чем заняться, чтобы улуч- } \\
\text { шить себе настроение }\end{array}$ & 0 & 1 & 2 & 3 & By \\
\hline 5. & $\begin{array}{l}\text { У меня обычно не получается повлиять на } \\
\text { эмоциональное состояние своего собесед- } \\
\text { ника }\end{array}$ & 3 & 2 & 1 & 0 & MY \\
\hline 6. & $\begin{array}{l}\text { Когда я раздражаюсь, то не могу сдержать- } \\
\text { ся, и говорю всё, что думаю }\end{array}$ & 3 & 2 & 1 & 0 & $\mathrm{BЭ}$ \\
\hline 7. & $\begin{array}{l}\text { Я хорошо понимаю, почему мне нравятся } \\
\text { или не нравятся те или иные люди }\end{array}$ & 0 & 1 & 2 & 3 & ВП \\
\hline 8. & Я не сразу замечаю, когда начинаю злиться & 3 & 2 & 1 & 0 & $\mathrm{B \Pi}$ \\
\hline 9. & Я умею улучшить настроение окружающих & 0 & 1 & 2 & 3 & MY \\
\hline 10. & $\begin{array}{l}\text { Если я увлекаюсь разговором, то говорю } \\
\text { слишком громко и активно жестикулирую }\end{array}$ & 3 & 2 & 1 & 0 & ВЭ \\
\hline 11. & $\begin{array}{l}\text { Я понимаю душевное состояние некоторых } \\
\text { людей без слов }\end{array}$ & 0 & 1 & 2 & 3 & МП \\
\hline 12. & $\begin{array}{l}\text { В экстремальной ситуации я не могу уси- } \\
\text { лием воли взять себя в руки }\end{array}$ & 3 & 2 & 1 & 0 & By \\
\hline 13. & $\begin{array}{l}\text { Я легко понимаю мимику и жесты других } \\
\text { людей }\end{array}$ & 0 & 1 & 2 & 3 & МП \\
\hline 14. & Когда я злюсь, я знаю, почему & 0 & 1 & 2 & 3 & $\mathrm{B \Pi}$ \\
\hline 15. & $\begin{array}{l}\text { Я знаю, как ободрить человека, находяще- } \\
\text { гося в тяжелой ситуации }\end{array}$ & 0 & 1 & 2 & 3 & My \\
\hline 16. & $\begin{array}{l}\text { Окружающие считают меня слишком эмо- } \\
\text { циональным человеком }\end{array}$ & 3 & 2 & 1 & 0 & ВЭ \\
\hline 17. & $\begin{array}{l}\text { Я способен успокоить близких, когда они } \\
\text { находятся в напряжённом состоянии }\end{array}$ & 0 & 1 & 2 & 3 & МУ \\
\hline 18. & $\begin{array}{l}\text { Мне бывает трудно описать, что я чувст- } \\
\text { вую по отношению к другим }\end{array}$ & 3 & 2 & 1 & 0 & $\mathrm{~B} \Pi$ \\
\hline 19. & $\begin{array}{l}\text { Если я смущаюсь при общении с незнако- } \\
\text { мыми людьми, то могу это скрыть }\end{array}$ & 0 & 1 & 2 & 3 & ВЭ \\
\hline 20. & $\begin{array}{l}\text { Глядя на человека, я легко могу понять его } \\
\text { эмоциональное состояние }\end{array}$ & 0 & 1 & 2 & 3 & МП \\
\hline 21. & $\begin{array}{l}\text { Я контролирую выражение чувств на своем } \\
\text { лице }\end{array}$ & 0 & 1 & 2 & 3 & $\mathrm{~B} Э$ \\
\hline 22. & $\begin{array}{l}\text { Бывает, что я не понимаю, почему испыты- } \\
\text { ваю то или иное чувство }\end{array}$ & 3 & 2 & 1 & 0 & ВП \\
\hline 23. & $\begin{array}{l}\text { В критических ситуациях я умею контро- } \\
\text { лировать выражение своих эмоций }\end{array}$ & 0 & 1 & 2 & 3 & ВЭ \\
\hline 24. & Если надо, я могу разозлить человека & 0 & 1 & 2 & 3 & MY \\
\hline 25. & $\begin{array}{l}\text { Когда я испытываю положительные эмо- } \\
\text { ции, я знаю, как поддержать это состояние }\end{array}$ & 0 & 1 & 2 & 3 & By \\
\hline
\end{tabular}




\section{Продолжение интерпретации опросника}

\begin{tabular}{|c|c|c|c|c|c|c|}
\hline № & Утверждение & $\begin{array}{l}\text { Совсем } \\
\text { не со- } \\
\text { гласен }\end{array}$ & $\begin{array}{l}\text { Скорее } \\
\text { не со- } \\
\text { гласен }\end{array}$ & $\begin{array}{l}\text { Скорее } \\
\text { согласен }\end{array}$ & $\begin{array}{l}\text { Полностью } \\
\text { согласен }\end{array}$ & Шкала \\
\hline 26. & $\begin{array}{l}\text { Как правило, я понимаю, какую эмоцию } \\
\text { испытываю }\end{array}$ & 0 & 1 & 2 & 3 & ВП \\
\hline 27. & $\begin{array}{l}\text { Если собеседник пытается скрыть свои } \\
\text { эмоции, я сразу чувствую это }\end{array}$ & 0 & 1 & 2 & 3 & МП \\
\hline 28. & Я знаю как успокоиться, если я разозлился & 0 & 1 & 2 & 3 & BУ \\
\hline 29. & $\begin{array}{l}\text { Можно определить, что чувствует человек, } \\
\text { просто прислушиваясь к звучанию его го- } \\
\text { лоса }\end{array}$ & 0 & 1 & 2 & 3 & МП \\
\hline 30. & $\begin{array}{l}\text { Я не умею управлять эмоциями других } \\
\text { людей }\end{array}$ & 3 & 2 & 1 & 0 & My \\
\hline 31. & $\begin{array}{l}\text { Мне трудно отличить чувство вины от чув- } \\
\text { ства стыда }\end{array}$ & 3 & 2 & 1 & 0 & ВП \\
\hline 32. & $\begin{array}{l}\text { Я умею точно угадывать, что чувствуют } \\
\text { мои знакомые }\end{array}$ & 0 & 1 & 2 & 3 & МП \\
\hline 33. & $\begin{array}{l}\text { Мне трудно справляться с плохим настрое- } \\
\text { нием }\end{array}$ & 3 & 2 & 1 & 0 & BУ \\
\hline 34. & $\begin{array}{l}\text { Если внимательно следить за выражением } \\
\text { лица человека, то можно понять, какие } \\
\text { эмоции он скрывает }\end{array}$ & 0 & 1 & 2 & 3 & МП \\
\hline 35. & $\begin{array}{l}\text { Я не нахожу слов, чтобы описать свои чув- } \\
\text { ства друзьям }\end{array}$ & 3 & 2 & 1 & 0 & $\mathrm{B \Pi}$ \\
\hline 36. & $\begin{array}{l}\text { Мне удаётся поддержать людей, которые } \\
\text { делятся со мной своими переживаниями }\end{array}$ & 0 & 1 & 2 & 3 & MY \\
\hline 37. & Я умею контролировать свои эмоции & 0 & 1 & 2 & 3 & BУ \\
\hline 38. & $\begin{array}{l}\text { Если мой собеседник начинает раздражать- } \\
\text { ся, я подчас замечаю это слишком поздно }\end{array}$ & 3 & 2 & 1 & 0 & МП \\
\hline 39. & $\begin{array}{l}\text { По интонациям моего голоса легко дога- } \\
\text { даться о том, что я чувствую }\end{array}$ & 3 & 2 & 1 & 0 & ВЭ \\
\hline 40. & Если близкий человек плачет, я теряюсь & 3 & 2 & 1 & 0 & MY \\
\hline 41. & $\begin{array}{l}\text { Мне бывает весело или грустно без всякой } \\
\text { причины }\end{array}$ & 3 & 2 & 1 & 0 & ВП \\
\hline 42. & $\begin{array}{l}\text { Мне трудно предвидеть смену настроения } \\
\text { у окружающих меня людей }\end{array}$ & 3 & 2 & 1 & 0 & МП \\
\hline 43. & Я не умею преодолевать страх & 3 & 2 & 1 & 0 & BY \\
\hline 44. & $\begin{array}{l}\text { Бывает, что я хочу поддержать человека, а } \\
\text { он этого не чувствует, не понимает }\end{array}$ & 3 & 2 & 1 & 0 & MY \\
\hline 45. & $\begin{array}{l}\text { У меня бывают чувства, которые я не могу } \\
\text { точно определить }\end{array}$ & 3 & 2 & 1 & 0 & ВП \\
\hline 46. & $\begin{array}{l}\text { Я не понимаю, почему некоторые люди на } \\
\text { меня обижаются }\end{array}$ & 3 & 2 & 1 & 0 & МП \\
\hline
\end{tabular}

\section{Сокращения:}

МП - понимание чужих эмоций;

МУ - управление чужими эмоциями;

ВП - понимание своих эмоций; 
ВУ - управление своими эмоциями;

ВЭ - контроль экспрессии.

Подсчет баллов по шкалам:

Межличностный эмоциональный интеллект = МП + МУ

Внутриличностный эмоциональный интеллект $=$ ВП + ВУ + ВЭ

Понимание эмоций $=$ МП + ВП

Управление эмоциями $=$ МУ + ВУ + ВЭ

Общий уровень эмоционального интеллекта $=$ МП + МУ + ВП+ $+\mathrm{BY}+\mathrm{B} \ni$

Интерпретация результатов:

\begin{tabular}{|l|l|l|l|l|l|}
\hline Шкала & $\begin{array}{c}\text { Очень низкое } \\
\text { значение }\end{array}$ & $\begin{array}{c}\text { Низкое } \\
\text { значение }\end{array}$ & $\begin{array}{c}\text { Среднее } \\
\text { значение }\end{array}$ & $\begin{array}{c}\text { Высокое } \\
\text { значение }\end{array}$ & $\begin{array}{c}\text { Очень высо- } \\
\text { кое 3начение }\end{array}$ \\
\hline МП & $0-19$ & $20-22$ & $23-26$ & $27-30$ & От 31 \\
\hline МУ & $0-14$ & $15-17$ & $18-21$ & $22-24$ & От 25 \\
\hline ВП & $0-13$ & $14-16$ & $17-21$ & $22-25$ & От 26 \\
\hline ВУ & $0-9$ & $10-12$ & $13-15$ & $16-17$ & От 18 \\
\hline ВЭ & $0-6$ & $7-9$ & $10-12$ & $13-15$ & От 16 \\
\hline МЭИ & $0-34$ & $35-39$ & $40-46$ & $47-52$ & От 53 \\
\hline ВЭИ & $0-33$ & $34-38$ & $39-47$ & $48-54$ & От 55 \\
\hline ПЭ & $0-34$ & $35-39$ & $40-47$ & $48-53$ & От 54 \\
\hline УЭ & $0-33$ & $34-39$ & $40-47$ & $48-53$ & От 54 \\
\hline ОЭИ & $0-71$ & $72-78$ & $79-92$ & $93-104$ & От 105 \\
\hline
\end{tabular}




\section{ПРИЛОЖЕНИЕ Г}

\section{БЛАНК ОПРОСА СОТРУДНИКА СБЫТОВОГО ОТДЕЛА}

1. Ваше имя

2. Ваш возраст

3. Пол

4. Бренд продаваемого товара (нужное подчеркнуть): масс / премиум

5. Среднесписочная численность персонала на предприятии (чел.)

6. Укажите Ваш опыт работы (лет)

7. Заполните, пожалуйста, таблицу ниже. Предоставление данных за больший период приветствуется:

\begin{tabular}{|c|c|c|c|c|}
\hline $\begin{array}{l}\text { Период } \\
\text { ( } \square \text { ecc.) }\end{array}$ & $\begin{array}{c}\text { Коэффициент выпол- } \\
\text { нения плана продаж } \\
\text { (отношение факта про- } \\
\text { даж к плану) }\end{array}$ & $\begin{array}{c}\text { Конверсия по } \\
\text { звонкам (отноше- } \\
\text { ние визитов по } \\
\text { звонку к общему } \\
\text { числу звонков) }\end{array}$ & $\begin{array}{c}\text { Конверсия по } \\
\text { визитам (отно- } \\
\text { шение контрак- } \\
\text { тов по звонку к } \\
\text { общему числу } \\
\text { визитов) }\end{array}$ & $\begin{array}{c}\text { Размер при- } \\
\text { были по про- } \\
\text { данным еди- } \\
\text { ницам (\%) }\end{array}$ \\
\hline 1 & & & & \\
\hline 2 & & & & \\
\hline 3 & & & & \\
\hline 4 & & & & \\
\hline 5 & & & & \\
\hline 6 & & & & \\
\hline 7 & & & & \\
\hline 8 & & & & \\
\hline 9 & & & & \\
\hline 10 & & & & \\
\hline 11 & & & & \\
\hline 12 & & & & \\
\hline
\end{tabular}





\section{СВЕДЕНИЯ ОБ АВТОРАХ:}

Кельчевская Наталья Рэмовна - доктор экономических наук, профессор, Заслуженный работник Высшей школы РФ, зав. кафедрой экономики и управления на металлургических и машиностроительных предприятиях Института экономики и управления Уральского федерального университета.

Пелымская Ирина Сергеевна - кандидат экономических наук, доцент, доцент кафедры экономики и управления на металлургических и машиностроительных предприятиях Института экономики и управления Уральского федерального университета.

Чешко Елизавета Константиновна - магистрант кафедры экономики и управления на металлургических и машиностроительных предприятиях Института экономики и управления Уральского федерального университета. 


\title{
Кельчевская Наталья Рэмовна \\ Пелымская Ирина Сергеевна \\ Чешко Елизавета Константиновна
}

\section{ВЛИЯНИЕ ЭМОЦИОНАЛЬНОГО ИНТЕЛЛЕКТА РАБОТНИКОВ ПРЕДПРИЯТИЯ НА РЕЗУЛЬТАТЫ ЕГО ДЕЯТЕЛЬНОСТИ}

\author{
монография
}

Выпускающий редактор: Цветкова А.В.

Корректор: Бородина Л.В.

Верстальщик: Журавлева В.А.

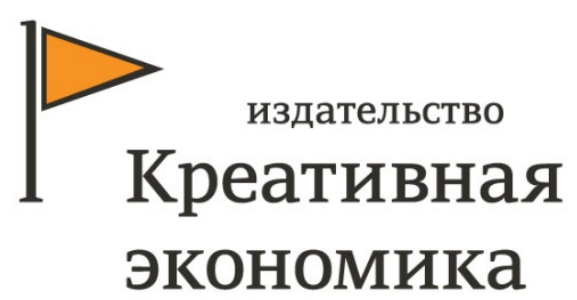

\footnotetext{
Усл. печ. л. 10,23. Тираж 500 экз.

Подписано в печать 24.09.2020

Формат: 60x84/16
}

\section{Информация для авторов: \\ www.creativeconomy.ru}

\author{
Отпечатано: ПАО «Т8 Издательские Технологии» \\ 109316 Москва, Волгоградский проспект, дом 42, корпус \\ 5 Тел.: +7 (499) 322-38-30
}

